\title{
DEVELOPMENT OF AN ADVANCED, CONTINUOUS MILD GASIFICATION PROCESS FOR THE PRODUCTION OF CO-PRODUCTS \\ $\mathrm{DOE} / \mathrm{MC} / 24266--2925$ \\ DE91 005539
}

Progress Report for the Period October 1-December 31, 1989

Prepared by

R. A. Knight

J. Gissy

S. Kline

M. Onischak

S. P. Babu

INSTITUTE OF GAS TECHNOLOGY

and

R. G. Duthie

BECHTEL NATIONAL INC.

April 1990

Work Performed Under Contract No.: DE-AC21-87MC24266

For

U.S. Department of Energy

Office of Fossil Energy

Morgantown Energy Technology Center

Morgantown, West Virginia 26505

By

Institute of Gas Technology

3424 South State Street

Chicago, Illinois 60616 


\section{DISCLAIMER}

This report was prepared as an account of work sponsored by an agency of the United States government. Neither the United States Government nor any agency thereof, nor any of their employees, makes any warranty, express or implied, or assumes any legal liability or responsibility for the accuracy, completeness, or usefulness of any information, apparatus, product, or process disclosed, or represents that its use would not infringe privately owned rights. Reference herein to any specific commercial product, process, or service by trade name, trademark, manufacturer, or otherwise, does not necessarily constitute or imply its endorsement, recommendation, or favoring by the United States Government or any agency thereof. The views and opinions of authors expressed herein do not necessarily state or reflect those of the United States Government or any sgency thereof.

Printed in the United States of America

\section{Availablo from}

National Technical Information Service

U.S. Department of Commerce

5286 Port Royal Road

Springfield, VA 22161 


\section{SUMMARY}

During the quarter, eleven mild gasification tests were conducted in the 8-inch-I.D. process research unit (PRU). Illinois No. 6 coal was used in nine of the tests and a West Virginia metallurgical grade of coal was used in the last two tests. Both coals were obtained from Peabody Coal Company preparation plants. The West Virginia coal had a much finer size consist, more than 908 smaller than 40 mesh, than the -12 mesh Illinois No. 6 coal. The West Virginia coal also exhibited a free swelling index value of $5-1 / 2$ compared to a value of $1-1 / 2$ for the Illinois coal. Because of these characteristics, the West Virginia coal was diluted with coke for the initial tests in a ratio of one pound coal to two pounds coke.

The tests conducted in the PRU this quarter were operated with feed rates about three times higher than those used in the last quarter. These tests added information to complete the investigation of the effect, initiated last. quarter, of mild gasification temperature on Illinois No. 6 coal. The results presented show the effect of process temperature on the yields of char, oils/ tars, and gases. Various compositional effects on the oils/tars were also discovered.

Char upgrading studies were completed for the char co-product options of smokeless fuel and adsorbent char, showing that mild gasification chars from the Illinois coal could be processed into these products. Work will continue on the formcoke product option for the West Virginia coal.

A total condensate collection system was designed for the PRU system. Components were ordered and will be installed in the next quarter. The system integration study has progressed in developing a process design for the 24 ton-per-day process development unit (PDU) with a material and energy balance. The PDU design is site-specific for a site at the Illinois Coal Development Park in Carterville, Illinois, operated by Southern Illinois University at Carbondale. The PDU process design incorporates two alternative methods of heat supply for the mild gasification reactor: heating a portion of the product gas for recycle to the gasifier, or heating a portion of the char for introduction to the gasifier. 
TABLE OF CONTENTS

$\underline{\text { Page }}$

INTRODUCTION

1

TECHNICAL DISCUSSION

Task 2. Bench-Scale Mild Gasification Study

Summary of Mild Gasification Tests

Discussion of PRU Test Results

Material Balances for the PRU Tests

Task 3. Bench-Scale Char Upgrading study

Task 4. System Integration studies

APPENDIX A. Laboratory Analyses of Solids, Liquids, and Gases for Tests Conducted During the Quarter

$A-1$ 
Effect of Mild Gasification Temperatu'e on Co-Product Yields

Effect of Mild Gasification Temperature on Boiling Fractions of Oils/Tars

Effect of Mild Gasification Temperature on Heteroatoms in Oils/Tars

Effect of Mild Gasification Temperature on N/C and $\mathrm{S} / \mathrm{C}$ Ratios in Oils/Tars

Effect of Mild Gasification Temperature on H/C Atomic Ratio in oils/Tars

Effect of Mild Gasification Temperature on Ash and V.M. Content of Char

Effect of Mild Gasification Temperature on Gas Composition 20 Sulfur Forms in Combusted Smokeless Fuel Adsorption Properties of Activated Char

Adsorption Properties of Char Versus Activation Time

Adsorption Properties of Char versus Carbon Burnoff

Adsorption Properties Per Gram of Char Versus Carbon Burnoff

Diametral Tests for Tensile Strength of Briquettes

Formcoke Reactivity Tests

Schematic Diagram of the Total Condensate System

Process Flow Diagram for 24 TPD PDU -- Coal Feed and Drying Unit

Process Flow Diagram for 24 TPD PDU -- Gasification and Heat Supply Unit

Process Flow Diagram for 24 TPD PDU -- Liquids Recovery System 
LIST OF FIGURES, Cont.

Figure No.

Page

21

Process Flow Diagram for 24 TPD PDU -- Char Siorage and Handling and Emission Control

Process Flow Diagram for 24 TPD PDU -- Liquids Storage and Handling

viii 
Table No.

Page

1.

Analyses of Test Coals

6

2

Summary of Mild Gasification Tests Conducted During

the Quarter

7

3

Comparison of PAH Content of MG-25 Tar With a Typical

Coke-Oven Tax

Comparison of Co-Product Yields With Coke Oven By-product Yields

Comparison of PAH Production Levels Between Mild Gasification and a Typical coke Oven Tar 


\section{INTIRODUC'TION}

The U.S. Department of Energy (DOE) is supporting the development of milc' gasification technology to produce coal-derived fuols and chemical feedstocks. Mild gasification may be the most affordable route to increase coal utilization in the present economic climate. Mild gasification uses operating conditions of $1000^{\circ}$ to $1500^{\circ} \mathrm{F}$, near-atmospheric pressure, and inexpensive reactants to convert coal to a slate of co-products. In contrast, gasification and hydrogasification processes operate at temperatures of up to $1800^{\circ} \mathrm{F}$ and pressures up to 1000 psig.

Mild gasification could be considered as an advanced low-temperature coal carbonization process. Low-temperature carbonization of coal was popular in the U.S. until natural gas became abundantly available, and it is still used on a commercial scale in some foreign countries. The old technology, however, has been improved to produce value-added co-products through the application of technical and scientific knowledge about coal conversion that has been developed over the past twenty-five years. Improvements in reactor arid process design are being applied to significantly enhance the yield and quality of co-products as well as the overall economics of the technology. Because of the mild operating conditions and process simplicity, mild gasification is anticipated to use available materials of construction and well-known engineering design and construction practices. As a result, the capital and operating costs are expected to be low. In this context, by successfully developing and marketing the co-products to derive the valueadded benefits, it should be possible to commercialize the technology within tua next ten years.

With the support of the U.S. DOE, a project team consisting of the Institute of Gas Technology, Peabody Holding Company, Inc., and Bechtel National, Thc., is developing a mild gasification process that uses a fluidized/entrained-bed reactor. This reactor is designed to process caking bituminous coals over a wide range of particle sizes without oxidative pretreatment, and also without the use of oxygen or air as reactants. Process heat, in the conceptual commercial reactor, would be provided by recycled hot char or high-temperature gases derived from burning a portion of the processderived fuel gases. Tro addition of an in-bed sulfur-capture agent such as calcium oxide to capture the hydrogen sulfide released during coal conversion 
is an option that is being explored. The co-product streams, consisting of char, fuel gas, water, and condensables, would be separated by conventional means such as cyclones, staged condensers, and recycle-oil scrubbers.

An isothermal process research unit (PRU) has been built at IGT, consisting of an 8-inch-I.D., 8-foot-long fluidized-bed section and a 4-inchI.D., 13-foot-long entrained flow section, externally heated by electrical heaters. The coal feed capacity is $100 \mathrm{lb} / \mathrm{h}$, and the coal can be fed either to the fluidized bed or to the freeboard region above the fluidized bed and below the entrained section. The stainless steel reactor vessel is designed for a maximum temperature and pressure of $1500^{\circ} \mathrm{F}$ and $50 \mathrm{psig}$, respectively. Figures 1 and 2 show the block flow diagram and an isometric layout of the PRU. 


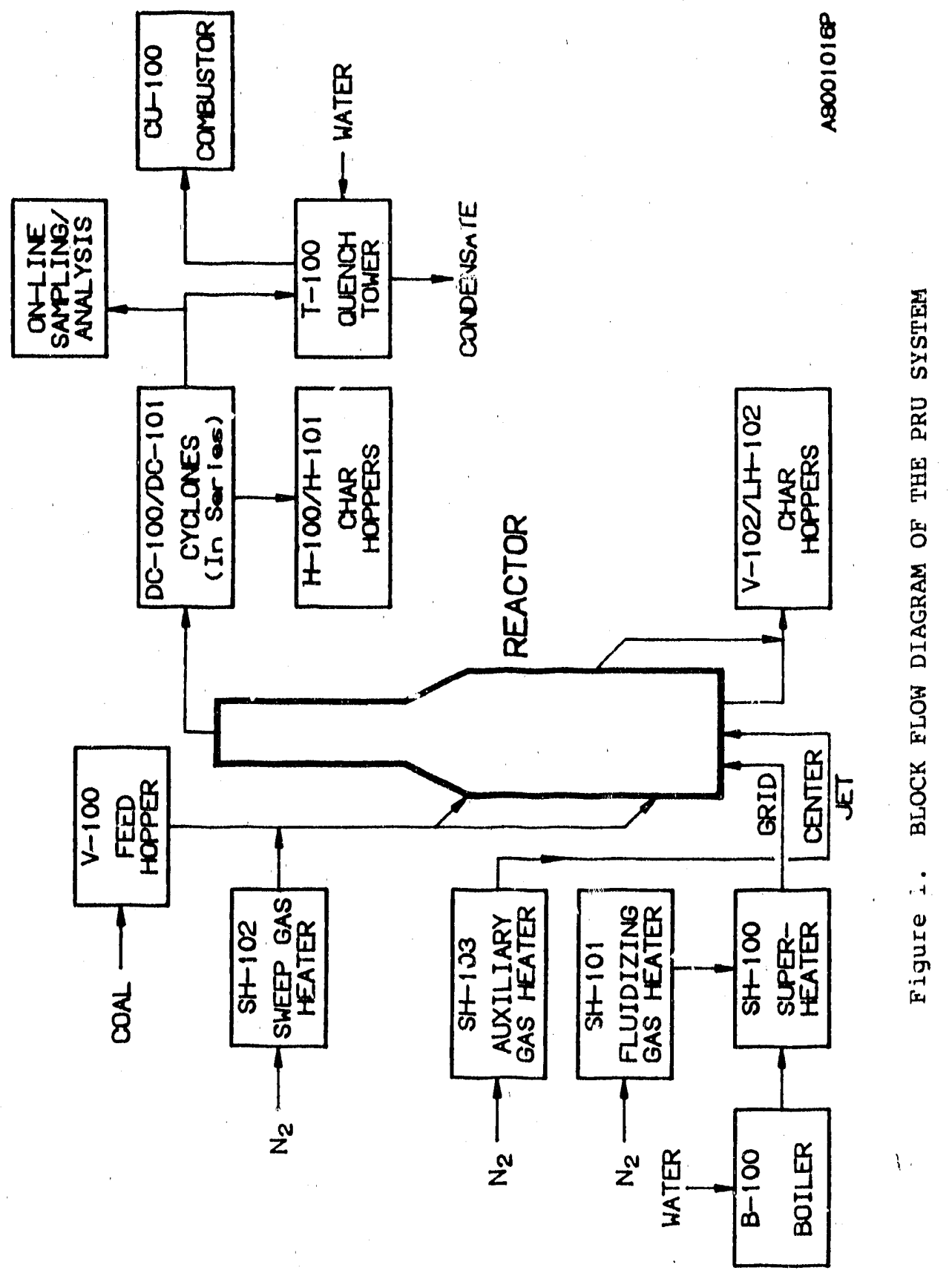




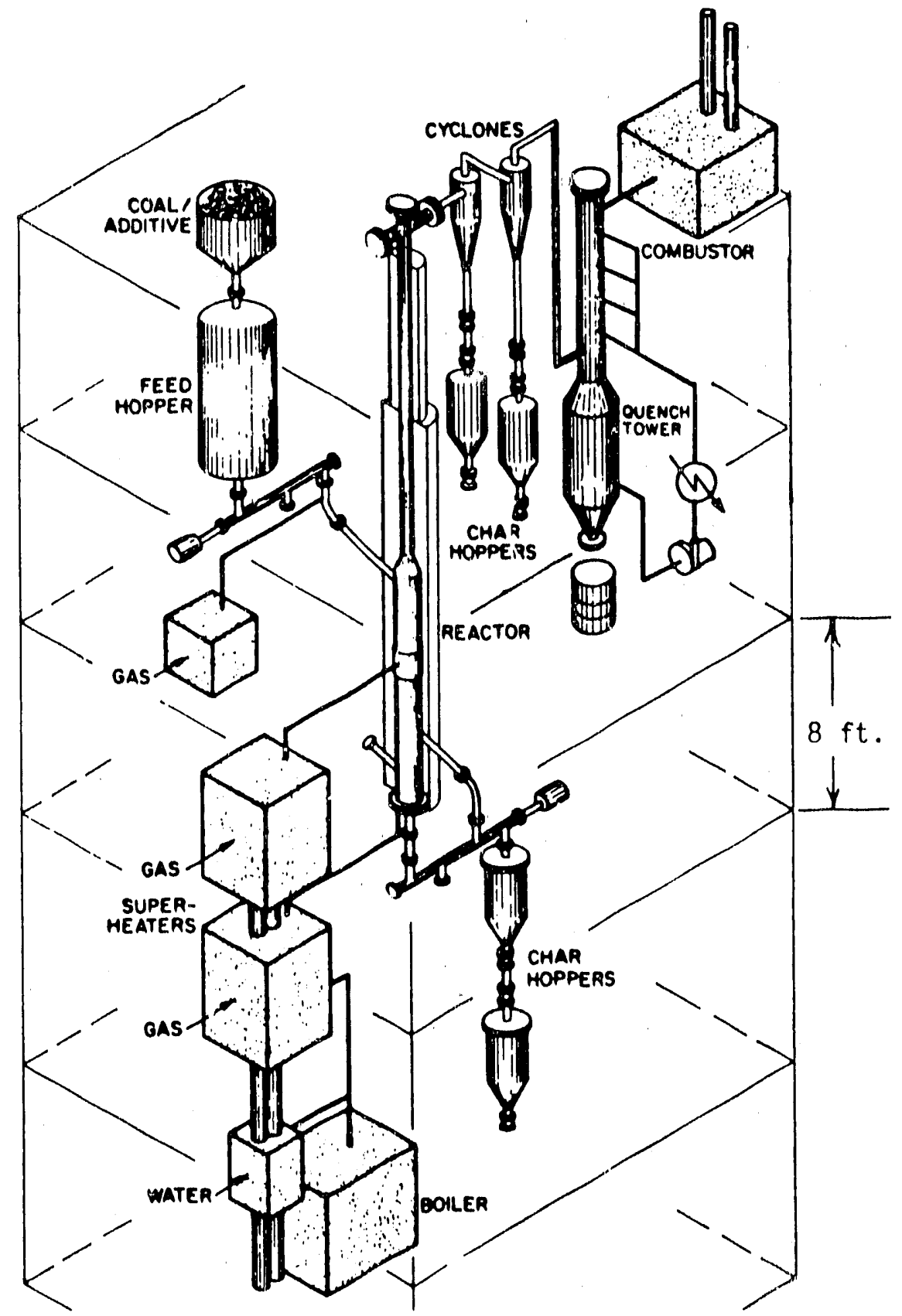

Figure 2. ISGMETRIC OF THE PRU SYSTEM 


\section{TECHNICAL DISCUSSION}

\section{Task 2. Bench-Scale Mild Gasification Study}

During the quarterly reporting period, 11 mild gasification tests wer conducted. The coal used in Tests MG-18 to MG-26 was a -12 mesh Illinois No. 6 coal obtained directly from a fines stream of Peabody's Randolph preparatiun plant in Baldwin, Iliinois. The coal used in Tests MG-27 and MG-28 was a West Virginia metallurgical-grade coal obtained from a Peabody preparation plant in West Virginia. The West Virginia coal has a much finer size consist than the Illinois coal. The proximate, ultimate, and particle size distribution of these coals as received are given in Table 1 . The process conditions used in these tests are summarized in Table 2 , and the tests are described in the following text. Detailed aralytical data from tests up to and including Test $M G-28$ are given in Appendix $A$. The results of tests conducted after this quarter and a discussion of the results will be reported in the topical report for Task 2 of this project, which will present the ontire test results obtained from slip-stream sampling of the volatile prodicts.

\section{Summary of Mild Gasification Tests}

Test MG-18 was operated with a higher steam rate and a higher fluidizedbed height to increase the char inventory in the bed. The char was removed via the char discharge nozzle located 15 inches above the gas distribution grid. The test ran smoothly for two hours, including a one-hour sampling period; however, shortly after the conclusion of the sampling period, the feed line became blocked. The feed line temperature at the feed hopper began to rise from its near-ambient level. This occurred because the hot feed sweep gas could not enter the reactor because of a small plug of material in the feed nozzle. The solid material recovered from the fluidized bed and the cyclones was free-flowing, so it appears that the agglomeration was localized at the feed point. The upset was correlated with a pressure pulse during a re-pressurization cycle of the first cyclone's lockhopper vessel.

Test MG-19 was conducted to repeat the higher feed rate conditions used in a previous test (Test MG-5), but with a deeper fluidized bed of a 36 inch height. This test also ran smoothly and parametric data were obtained in completing about two hours of operation until a pressure upset occurred during 
Tahle 1. ANALYSES OF TEST COALS

\section{Illinois No. 6 West Virginia}

\section{Proximate}

Moisture
Volatile Matter
Ash
Fixed Carbon
$\quad$ Total
Litimate
Ash
Carbon
Hydrogen
Nitrogen
Sulfur
Oxygen (by difference)
Total
HHV, Btu/lb (dry)
Free Swelling Index
U.S. Screen Size

12

20

40

60

80

100

140

200

230

270

325

Pan

Total

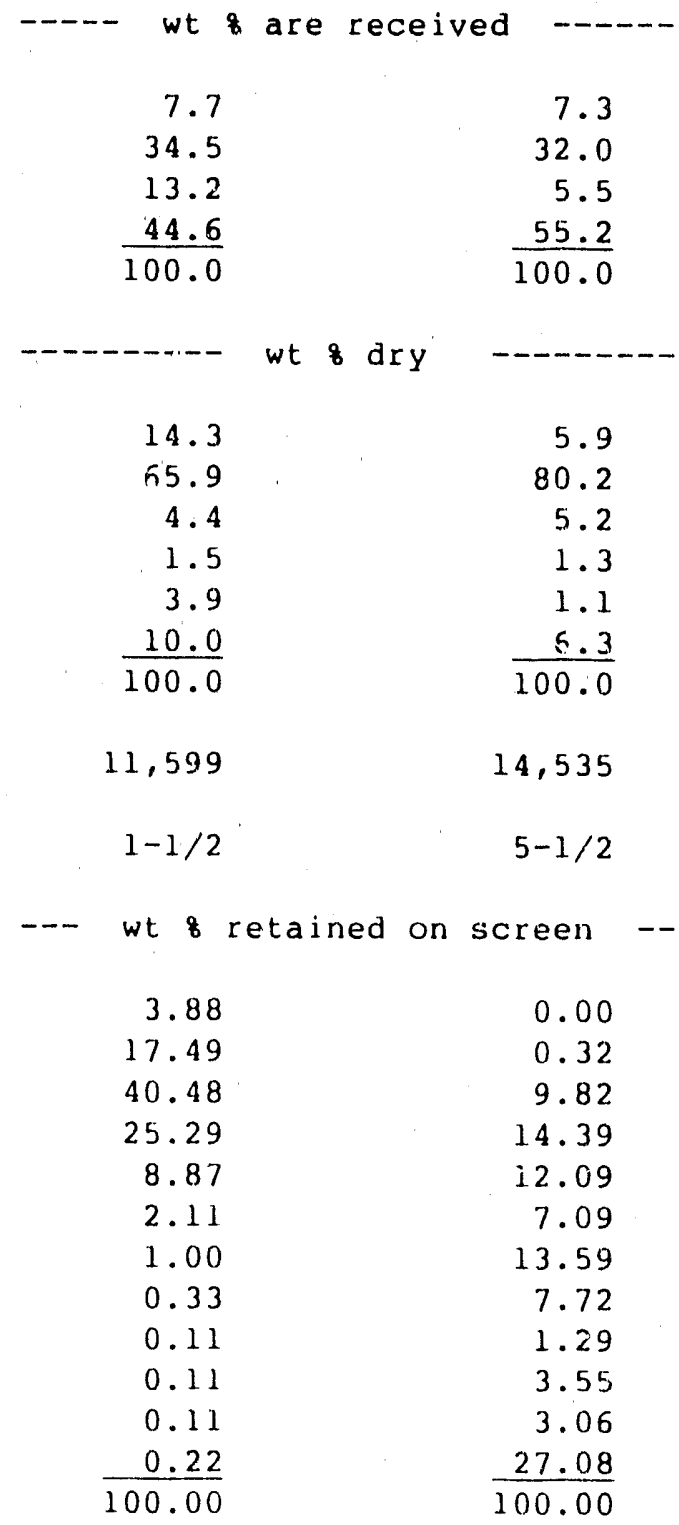

a Baldwin No. 1, Marissa and River King No. 6 Mines.

b No. 2 Gas and Campbell's Creek Seams. 
Table 2, Part 1. SUMMARY OF MILD GASIFICATION TESTS DURING THE QUARTER Test No.

\begin{tabular}{|c|c|c|c|c|}
\hline & & & & \\
\hline & $M G-18$ & $M G-19$ & $M G-20$ & $M G-21$ \\
\hline Purpose of Test & $\begin{array}{l}\text { Operate with } \\
\text { deeper bed, } \\
\text { greater char } \\
\text { inventory, } \\
\text { higher steam } \\
\text { rate }\end{array}$ & $\begin{array}{l}\text { Greater bed } \\
\text { height, } \\
\text { higher feed } \\
\text { rate, higher } \\
\text { steam rate }\end{array}$ & $\begin{array}{l}2001 \mathrm{~b} / \mathrm{h} \text { feed } \\
\text { rate }\end{array}$ & $\begin{array}{l}\text { Repeat of Test } \\
\text { MG-19 with } \\
\text { reduced steam } \\
\text { rate }\end{array}$ \\
\hline Feed Material & $\begin{array}{l}\text { l: } 1 \text { mixture } \\
\text { coala/coke }\end{array}$ & $\begin{array}{l}1: 1 \text { mixture } \\
\text { coala/coke }\end{array}$ & $\begin{array}{l}1: 1 \text { mixture } \\
\text { coala/coke }\end{array}$ & $\begin{array}{l}1: 1 \text { mixture } \\
\text { coala/coke }\end{array}$ \\
\hline Feed Rate, $1 \mathrm{~b} / \mathrm{h}$ & 48.2 & 90.8 & 93.8 & 94.0 \\
\hline Steam Rate, $1 \mathrm{~b} / \mathrm{h}$ & 23.4 & 23.7 & 18.2 & 8.5 \\
\hline Temperature, ${ }^{\circ} \mathrm{F}$ & 1178 & 1102 & 1120 & 1109 \\
\hline Pressure, psig & 10 & 17 & 10 & 10 \\
\hline Feed Location & $\begin{array}{l}\text { Fluidized } \\
\text { Bed }\end{array}$ & $\begin{array}{l}\text { Fluidized } \\
\text { Bed }\end{array}$ & $\begin{array}{l}\text { Fluidized } \\
\text { Bed }\end{array}$ & $\begin{array}{l}\text { Fluidized } \\
\text { Bed }\end{array}$ \\
\hline $\begin{array}{c}\text { Fluidized Bed } \\
\text { Height, } \mathrm{ft}\end{array}$ & 2.5 & 3.0 & 1.8 & 2.0 \\
\hline $\begin{array}{l}\text { Superficial Gas } \\
\text { Velocity, Et/s }\end{array}$ & 4.0 & $4 \cdot 4$ & 4.8 & 4.7 \\
\hline $\begin{array}{l}\text { Solids Residence } \\
\text { Time, min }\end{array}$ & 28 & 14 & -- & 10 \\
\hline $\begin{array}{l}\text { Steady state } \\
\text { Period, } h\end{array}$ & 2.0 & 2.0 & -- & 3.5 \\
\hline Remarks & $\begin{array}{l}\text { Successful } \\
\text { test } \\
\text { operation; } \\
35 \text { minutes } \\
\text { of sampling } \\
\text { before feed } \\
\text { interruption }\end{array}$ & $\begin{array}{l}\text { Successful } \\
\text { test } \\
\text { operation }\end{array}$ & $\begin{array}{l}\text { Start test } \\
\text { at } 100 \mathrm{lb} / \mathrm{h}, \\
\text { bed } \\
\text { defluidized } \\
\text { at } 200 \mathrm{lb} / \mathrm{h}\end{array}$ & $\begin{array}{l}\text { Successful } \\
\text { test } \\
\text { operation }\end{array}$ \\
\hline
\end{tabular}

a Illinois No: 6 coal, -12 mesh obtained from Peabody's Baldwin, Illinois prep plant. 
Table 2, Part 2. SUMMARY OF MILD GASIFICATION TESTS DURING THE QUARTER

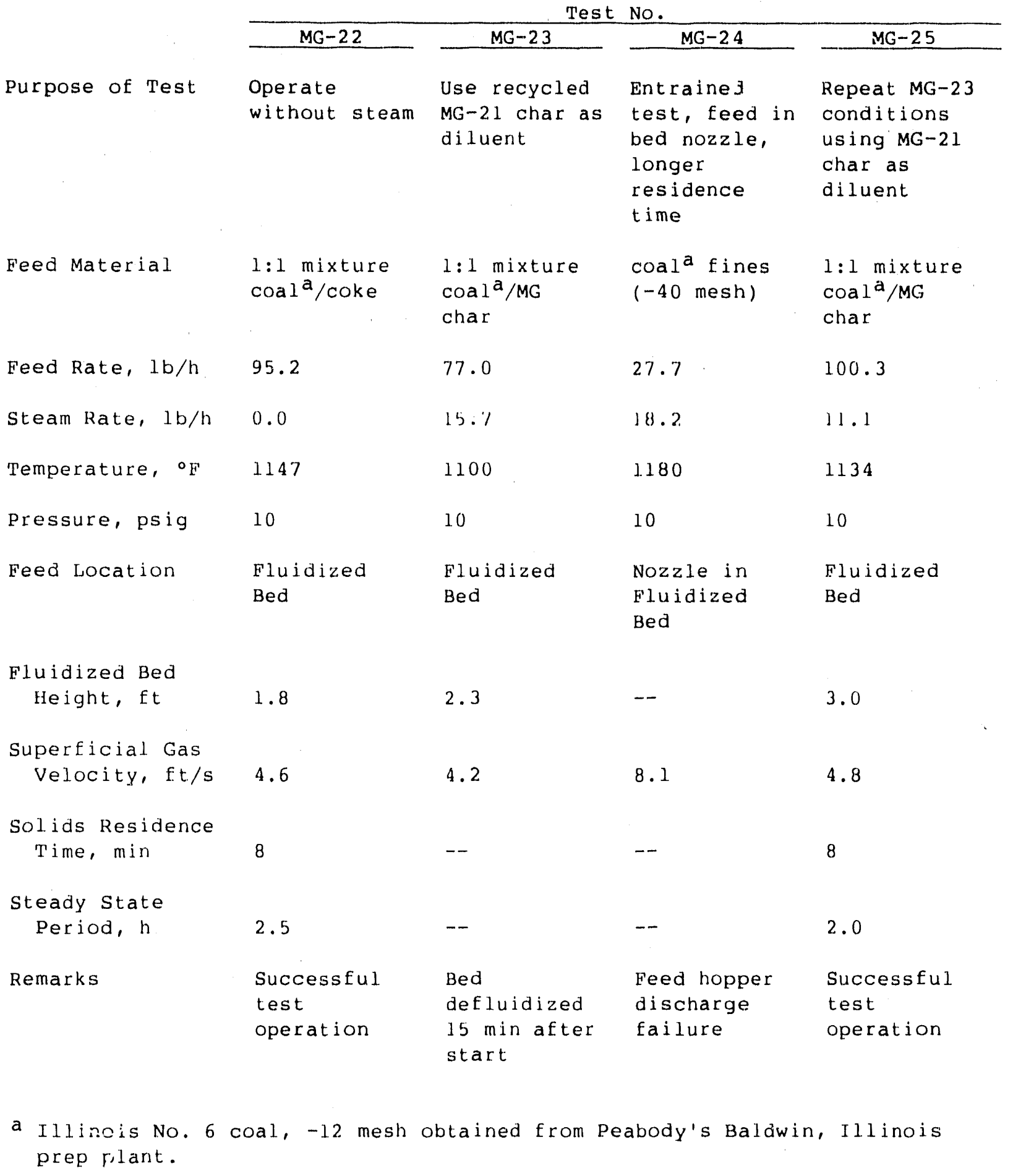


Table 2, Part 3. SUMMARY OF MILD GASIFICATION TESTS DURING THE QUARTER

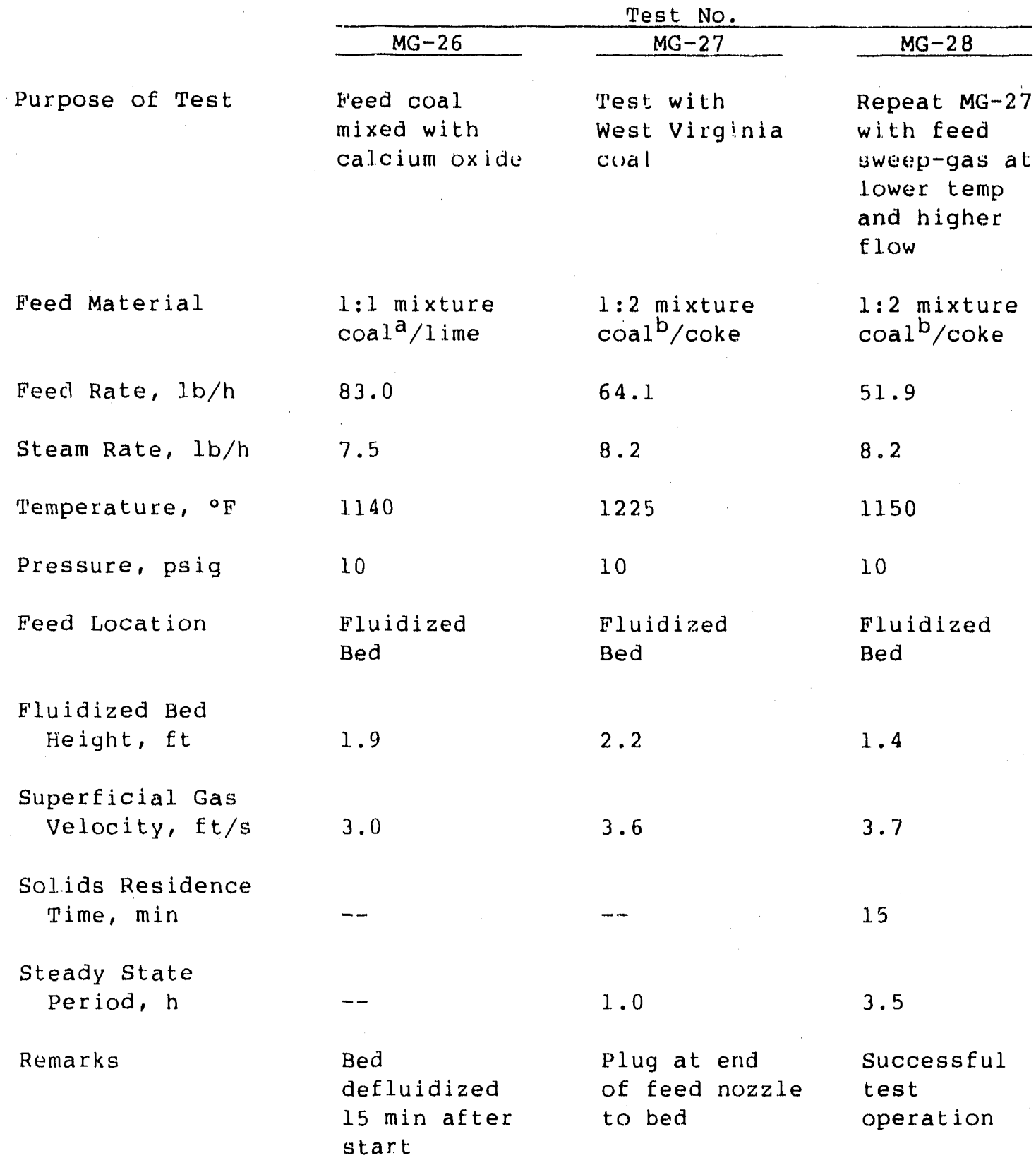

a Illinois No. 6 coal, -12 mesh obtained from Peabody's Baldwin, Illinois prep plant.

b West Virginia coal, 908 below 40 mesh, obtained from Peabody's West Virginia prep plant. 
the re-pressurization of the first cyclone lockhopper. The cause of the pressure upsets was found to be a plugged instrumentation line to a differential pressure switch that allows operation of the lockhopper solids dump valve after the lockhopper is sufficiently vented. During repressurization, the system over-pressurized the lockhopper and the pulse affected the fluidized-bed operation. All of the system tubing lines for venting, pressurization, and pressure equalization were inspected and cleaned prior to the following test.

The goal for Test MG-20 was to increase the feed rate to $200 \mathrm{lb} / \mathrm{h}$. The test began normally with a smooth startup and steady operation with an initial feed rate of $93.8 \mathrm{lb} / \mathrm{h}$ for 45 mirutes. At that time, the feed rate was increased to about $200 \mathrm{lb} / \mathrm{h}$. After ten minutes at this rate, the fluidized bed became defluidized and char stopped discharging from the bed. After the test, a clump of material was found in the fluidized bed, indicating that too much feed coal was entering the fluidized-bed reactor compared to the volume of bed char.

Tests MG-21 and MG-22 were conducted at the same conditions as Test MG-19 but with different steam inputs to the fluidized bed. These three tests will be used to analyze the effect of steam upon mild gasification and the production and quality of the co-products. For these three comparative tests, the feed rate range was from 91 to $95 \mathrm{lb} / \mathrm{h}$ and the temperature range was from $1100^{\circ}$ to $1150^{\circ} \mathrm{F}$.

T'est MG-23 was conducted with the purpose of reducing the amount of inert coke diluent used in the feed mixture for the tests. This was done by blending coal with the fluidized-bed char collected from a previous test, Test MG-21. An equal amount of Illinois No. 6 coal was blended with char from Test MG-21 to reduce the weight percentage of coke in the feed mixture from 508 to an estimated 32\%. In this way, the Illinois No. 6 coal-derived char in the feed mixture more closely simulated mild gasification with a recycle char stream. The char collected from this test would have been used to blend with coal again to further reduce the amount of coke in the feed mixture; however, about ore half-hour after the start of feeding the mixture with the reduced coke amount, a heater zone in the fluidized-bed zone failed and the fluidizedbed temperature declined, leading to test shutdown. 
Test MG-24 was conducted to investigate entrained flow gasification while waiting for a replacement heater element for the fluidized bed. In Test MG-24, the -40 mesh fines fractior of the coal was fed to the fluidized-bed nozzle rather than to the freeboard nozzle, to gain additional solids residence time. The entraining gas velocity in the 8 -inch section was set at $8 \mathrm{ft} / \mathrm{s}$ and, based on a gas-solids flow correlation, the solids residence time in the 8 -inch, 8 -foot section was calculated to be about 1.2 seconds. The 4 -inch piping above the 8 -inch zone added another 0.4 second for a total solids residence time of 1.6 seconds.

This arrangement of the fines feed location was designed to improve upon Test MG-17, in which the coal fines were fed to the 8-inch diameter freeboard section above the fluidized bed. The fluidization velocity in Test MG-17 was $3 \mathrm{ft} / \mathrm{s}$ in the 8 -inch section. This was too low to entrain the fines and thus, they fell on the top of the fluidized bed and did not mix intc it. In Test MG-24, the feed hopper stopped discharging the fine particles after 35 minutes of feeding. Inspection after the test showed that fine particles were plugging the pressure equalizing line between the feed hopper and the reactor as well as two instrumentation lines connected to the cyclone-lockhopper system.

Test MG-25 was conducted to repeat the aborted Test MG-23, using the coal and recycle char from 'I'est MG-21 to reduce the amount of diluent coke in the feed mixture. The blended feed mixture was fed at $100 \mathrm{lb} / \mathrm{h}$ for two hours and the steady-state sampling period was completed before the feed was interrupted from the feed hopper. A plug in the feed line prevented the resumption of feeding and the test was stopped.

Test MG-26 investigated the addition of calcium oxide to the feed to react with hydrogen sulfide at the temperatures of mild gasification. The coal and calcium oxide were mixed in a $1: 1$ weight ratio without any diluent coke material to simplify analysis of the data. The feed rate was $85 \mathrm{lb} / \mathrm{h}$ and the fluidized-bed temperature was set at $1140^{\circ} \mathrm{F}$. The mixture, however, behaved like moist sand, resisting flow. The lest ran for 1 b minutes when the bed began to de-fluidize. After 50 minutes were spent trying to fluidize the bed, the feed rate of the mixture from the hopper could not be maintained uniformly, and the test was terminated. 
Calcium oxide is known to be reactive with moisture and to have a high heat of hydration. Thus, the mixture for Test MG-26 was prepared one hour before the test to avoid a temperaturs rise or change in physical characteristics of the mixture. In spite of this, the temperature in the drum did $r$ ise to about $250^{\circ} \mathrm{F}$ in the center and it was difficult to pour the feed.

Premixing of the 5y-moisture coal and the calcium oxide could be avoided in the PRU system with the addition of a second hopper and screw feeder for the calcium oxide or other additive. Prior to 'T'est MG-26, a five-gallon bucket of the coal and alcium oxide was prepared, used in 6-inch cold flow fluidization test column work, and stored for 48 hours afterward. In this quantity, no temperature $r$ ise was noted and the mixture was very free-flowing and easy to pour. This suggests that mixing at the point of contact would be successful.

Test MG-27 was the first test conducted to evaluate the mild gasification performance of the metallurgical-grade coal obtained from Peabody's preparation plant in West Virginia. The coal as received from West Virginia had a finer size consist than the Illinois No. 6 coal, as shown in Table 1 . The coal was mixed with diluent coke in a $1: 2$ weight ratio, because of its higher fines content and free swelling index compared to the tllinois no. 6 coal. This was done with the intent of increasing the coal:coke ratio for subsequent tests. The test proceeded well through two hours, after which the sampling period began. Five minutes into the sampling period, however, the feed line into the reactor became blocked. The blockage was temporarjly relieved by isolating the feed hopper and increasing the leed sweep yas flow through the nozzle, but the blockage developed again and the test was stopped. Inspection of the reactor, cyclones, and piping showed that everything was clean and the blockage was restricted to a one-half inch plug in the feed nozzle at the point where it enters the reactor. To eliminate this occurrence in the next test, the feed sweep gas temperature was reduced from $690^{\circ}$ to $500^{\circ} \mathrm{F}$ and the sweep gas velocity was increased.

Test MG-28 was conducted to repeat the conditions of Test MG-27. The temperature was $1170^{\circ} \mathrm{F}$ and the feed rate was $51.91 \mathrm{~b} / \mathrm{h}$. The test operated well for over 3.5 hours with a very steady flow of fluidized-bed char discharge and steady fluidized-bed differential pressure values. Solids recovered from the reactor after the test were free-flowing. 


\section{Discussion of PRU Test Results}

With the additional avallable analyzed data for Tests MG-11, 12, 14, 15, 16, 19, and the shakedown Test SD-6, an evaluation of the effect of temperature on the co-product yields, makeup, gas composition, and other selected properties of the oils and tars has been completed, and is presented in Figures 3 to 9 and in Tables 3 to 5. The material balances for each of the above tests are presented in the following section as Tables 6 through 11 .

Figure 3 shows the effect of mild gasification temperatures from $1034^{\circ}$ to $1390^{\circ} \mathrm{F}$ on the yields of gas and oils/tars observed from the seven tests listed above. As shown, the gas yield increases with temperature, whereas the maximum oils/tars yield appears to be at the lower end of the temperature range. The observed decrease in char yield is expected with an increasing temperature and the chemical water make appears fairly constant.

Figure 4 shows the influence of the process temperature on the boilingrange distribution of the oils and tars. It appears from these data that the principal change in the volatility of the condensables with lncreasing mild gasification temperature consists of an increase in light oils accompanied by a decrease in the fraction of material with a boiling point above $750^{\circ} \mathrm{F}$, which is defined as pitch.

Figures 5 and 6 show the manner in which the heteroatom content of the condensables (not including light oils) changes with the process temperature. Nitrogen and sulfur lovels increase slightly, whereas the oxygen content decreases sharply with an increasing mild gasification temperature. The decrease in oxygen content signals the loss of oxygen functionalities, such as phenolic - $\mathrm{OH}$ groups, and may partially explain the decrease in pitch content at higher temperatures, whereby the removal of polar oxygen groups reduces the boilingpoint and shifts some pitch components into lower-boiling Eractions. The slight increase in $\mathrm{N}$ and $\mathrm{S}$ content with process temperature may indicate increasing incorporation of these heteroatoms into polycondensed aromatic rings.

The H/C ratio of the condensables, shown in Figure 7 , also changes with process temperature. The decrease in the H/C ratio is consistent with $a^{\text {? }}$ increase in aromaticity with process temperature. 


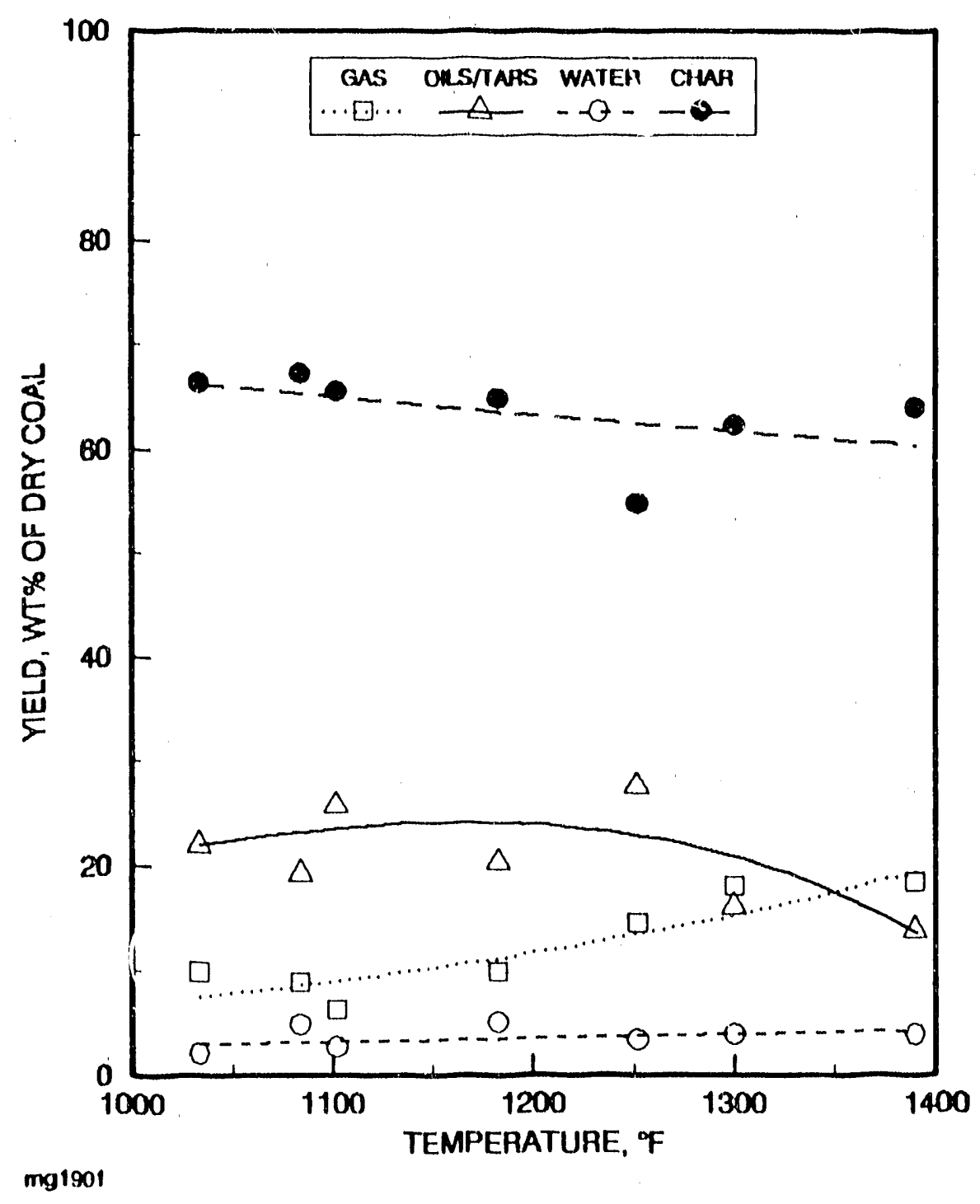

Figure 3. EFFECT OF MILD GASIFICATION TEMPERATURE ON CO-PRODUCT YIELDS 


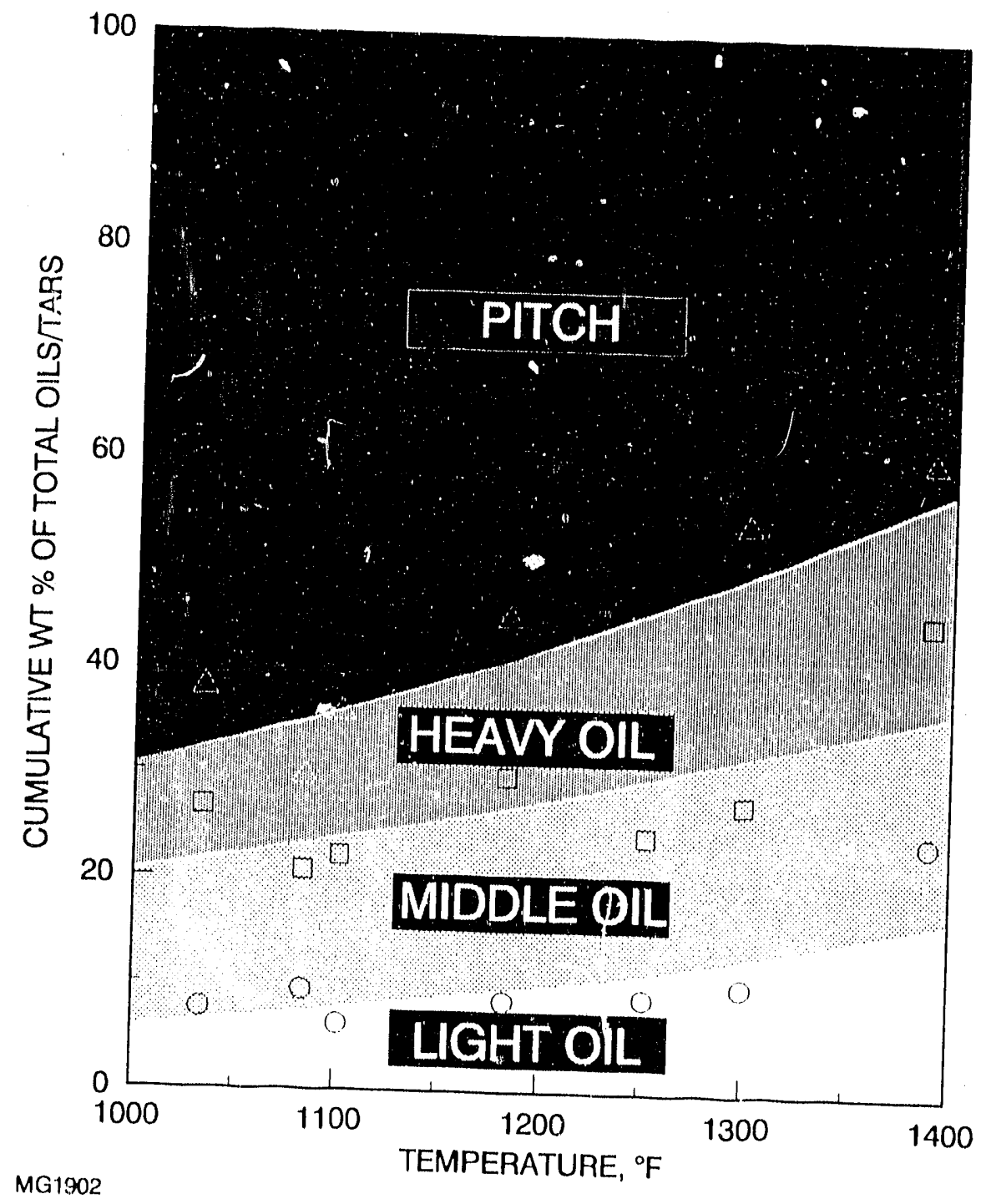

Figure 4. EFFECT OF MILD GASIFICATION TEMPERATURE ON THE BOILING FRAC'TIUNS OF OILS/TARS 


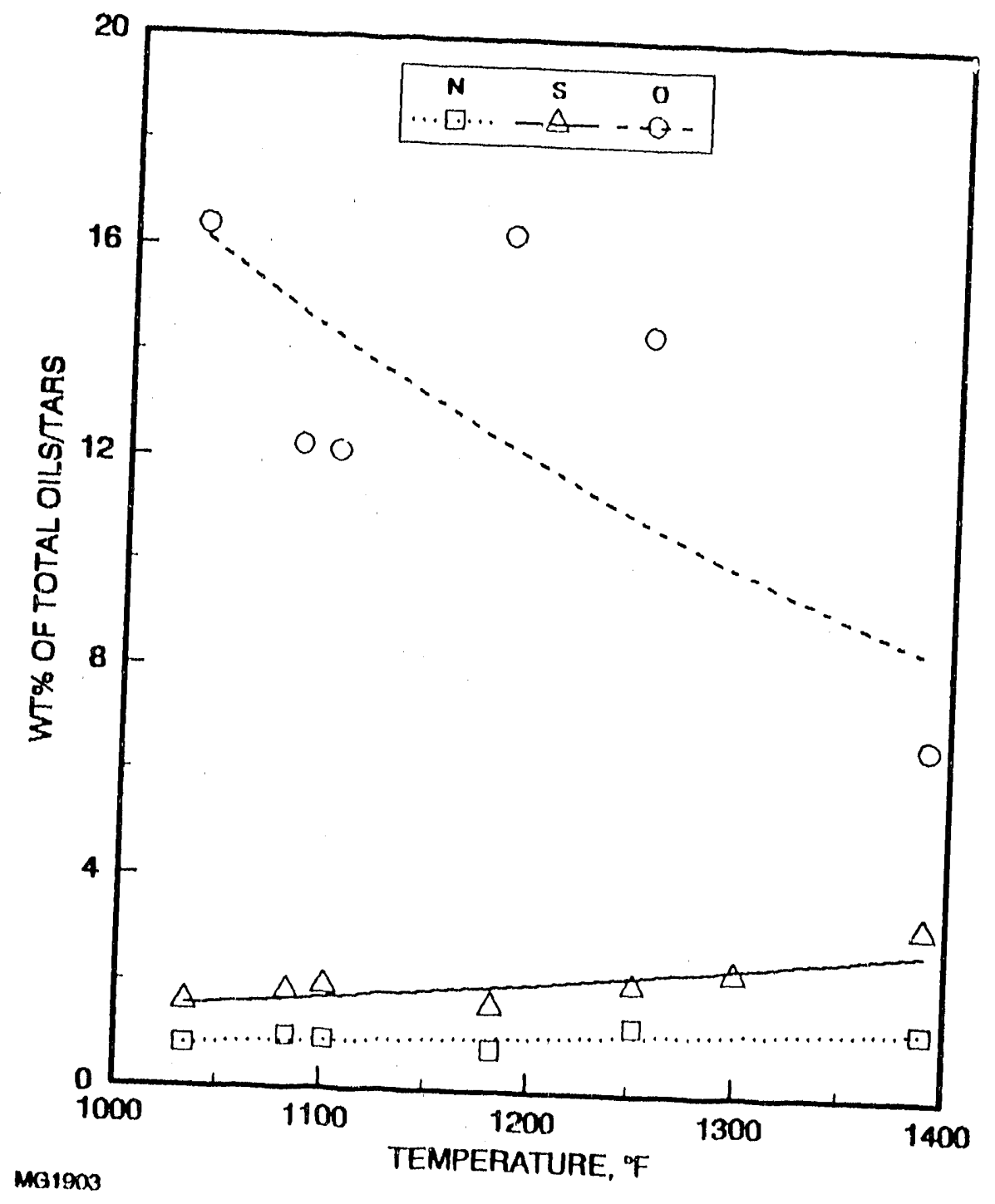

Figure 5. EFEECT OF MILD GASIFICATION TEMPERATURE ON
HETEROATOMS IN OILS/TARS 


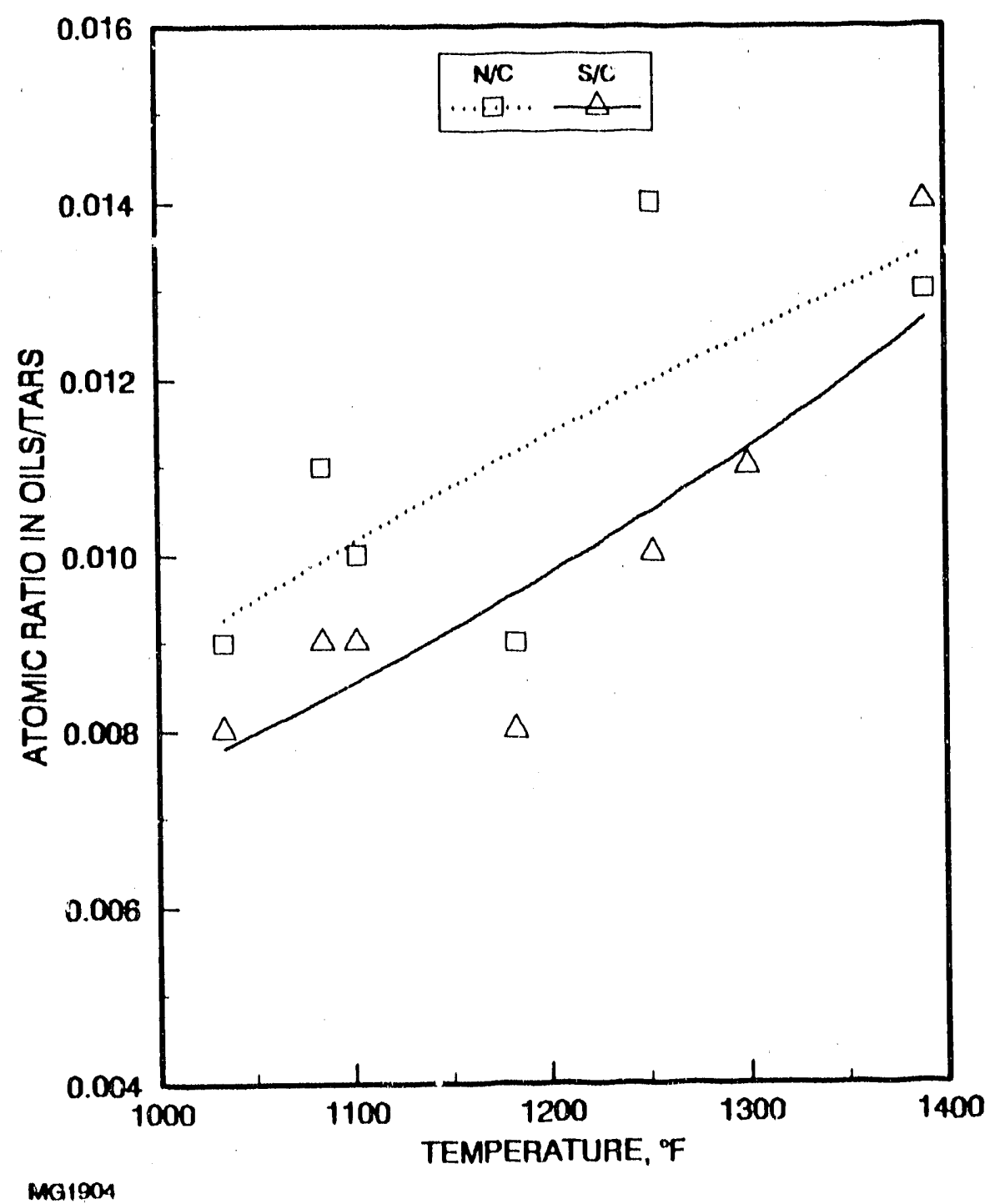

Figure 6. EFFECT OF MILD GASTFICATION TLMPERATURE ON $\mathrm{N} / \mathrm{C}$ AND S/C RA'IIOS IN OIISS/I'ARS 


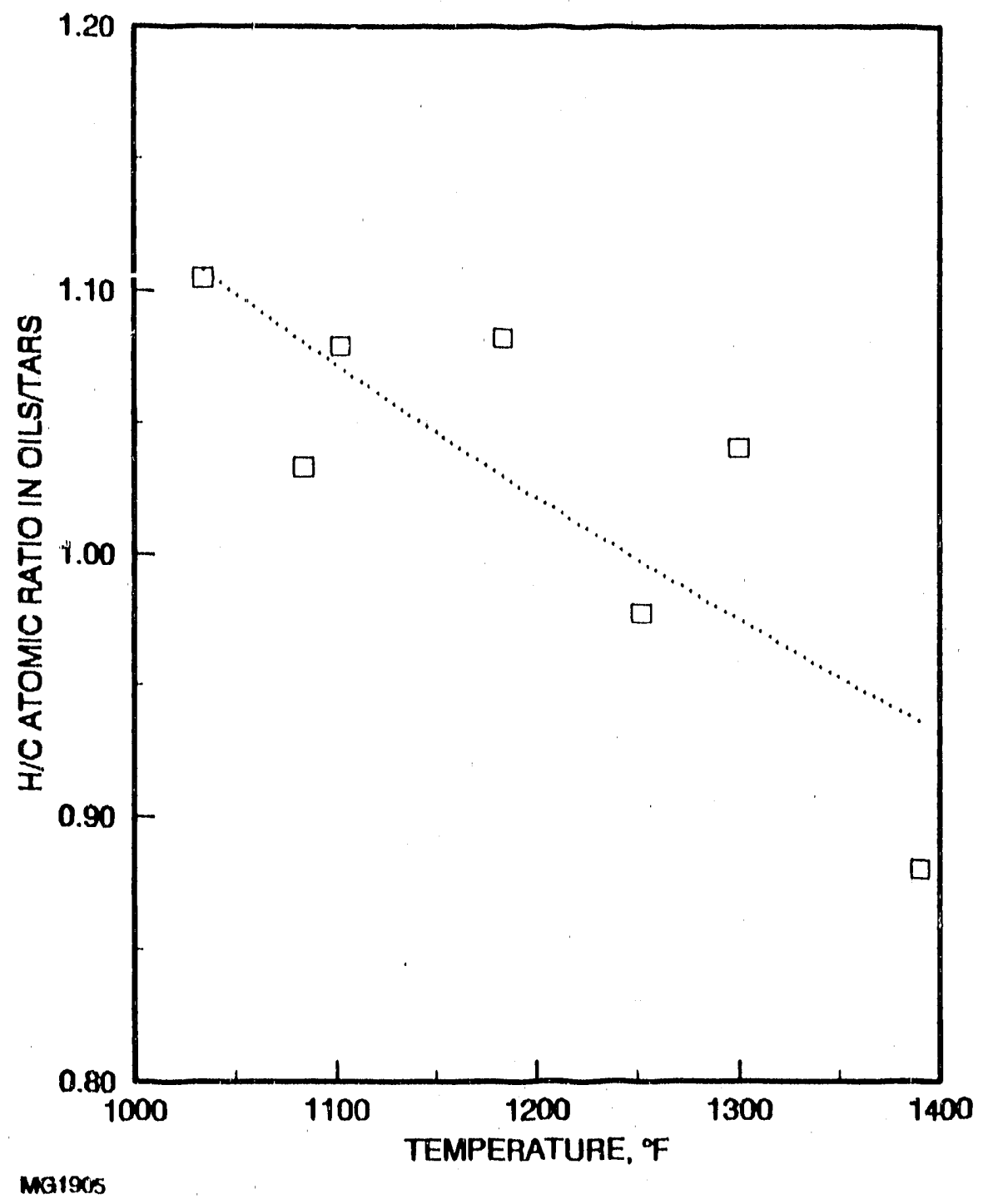

Figure 7. EFFECT OF MILD GASIFICATION T'EMPERATURE ON H/C ATOMIC RATIO IN OILS/TARS 


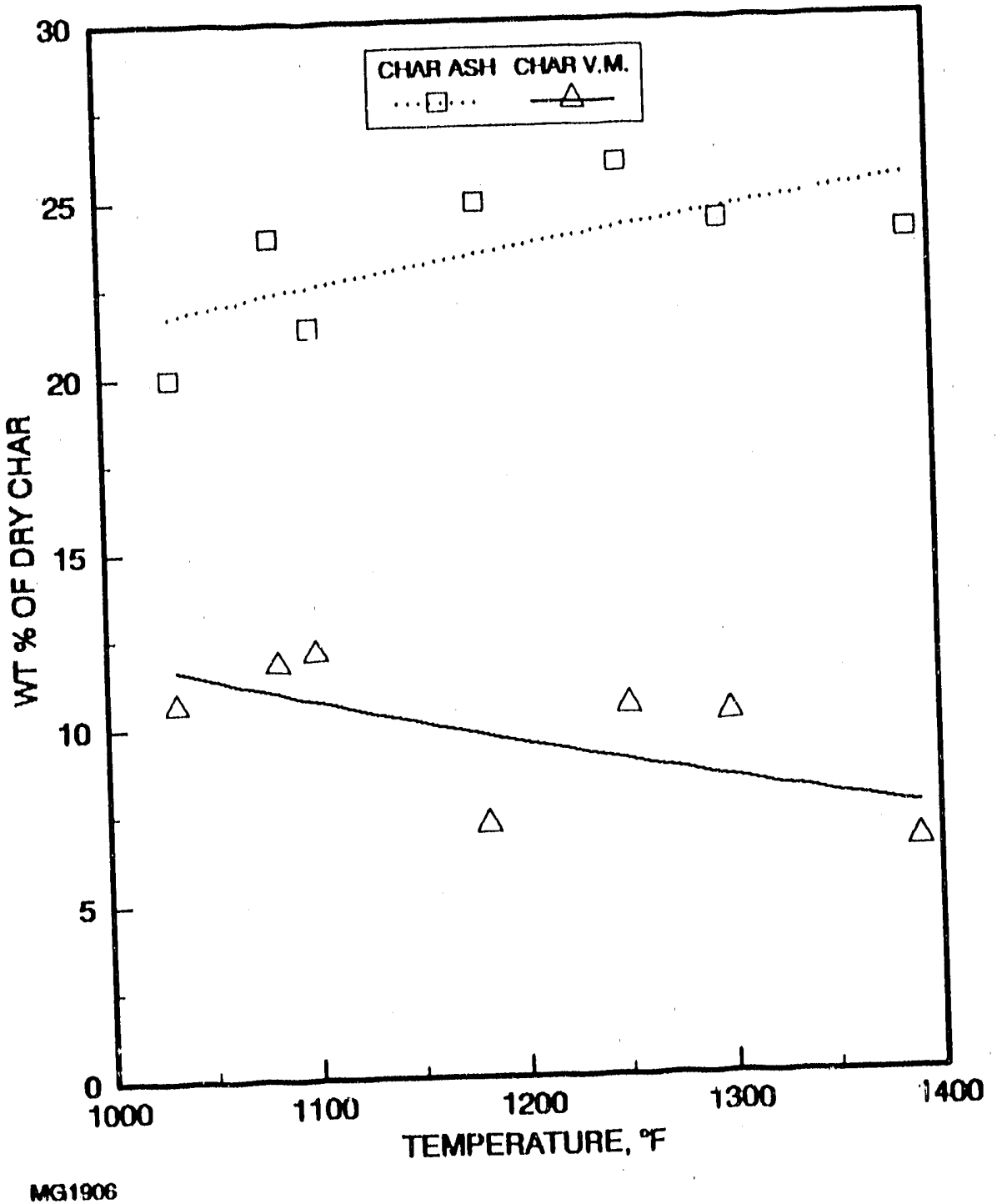

Figure 8. EFFECT OF MILD GASIFICATION TEMPERATURE ON ASH AND V.M. CONTENT OF CHAR 


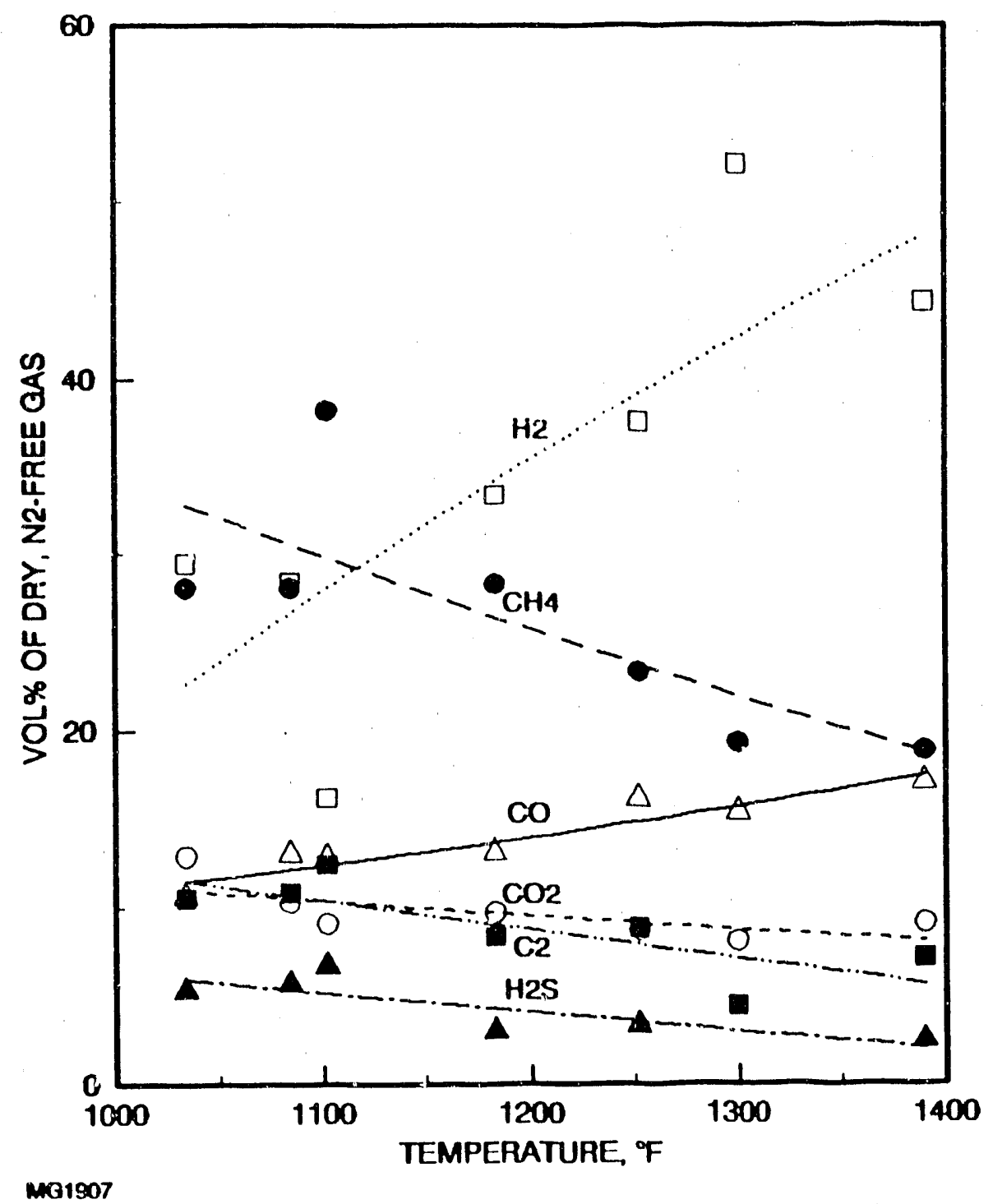

Figure 9. EFFECT OF MILD GASIFICATION TEMPERATURE ON GAS COMPOSITION 
Table 3. COMPARISON OF PAH CONTENT OF MG-25 TAR WITH A TYPIJAL COKE-OVEN TAR

\begin{tabular}{lcc}
\multicolumn{1}{c}{ Component } & $\begin{array}{c}\text { MG-25 Tar } \\
\text { Weight } 8\end{array}$ & $\begin{array}{c}\text { Coke-Oven Tar } \\
\text { Weight } 8\end{array}$ \\
\cline { 2 - 3 } Biphenyl & 0.010 & 0.420 \\
Acenaphthene & 0.011 & 1.280 \\
Fluorene & 0.027 & 2.560 \\
Phenanthrene/Anthracene & 0.066 & 2.870 \\
2-Methylphenanthrene & 0.083 & 0.700 \\
l-Methylphenanthrene & 0.064 & 0.750 \\
Fluoranthene & 0.003 & 0.531 \\
Pyrene & 0.015 & 0.520 \\
Benz(a)anthracene & 0.019 & 0.304 \\
Chrysene/Triphenylene & not detected & 0.221 \\
Benzo(b,k)fluoranthene & not detected & 0.354 \\
Benzo(a)pyrene & 0.017 & 0.293 \\
Dibenzo(a, h)anthracene & not detected & 0.039 \\
Benzo(g,h,i)perylene & 0.09 & 0.171
\end{tabular}

Table 4. COMPARISON OF CO-PRODUCT YIELDS WITH COKE OVEN BY-PRODUCT YIELDS Mild Gasification

$\frac{\text { (Test } M G-16)}{-\cdots \text { wt } 8 \text { maf coal Coke Oven }}$

$\begin{array}{lrr}\text { Product Gas } & 11.6 & 13.9 \\ \text { Oils/Tars } & 23.9 & 4.5 \\ \text { Water } & 5.9 & 14.1 \\ \text { Char or Coke } & 58.6 & 67.5\end{array}$


Table 5. COMPARISON OF PAH PRODUCTION LEVELS BETWEEN MILD GASIFICATION AND A TYPICAL COKE OVEN TAR

\begin{tabular}{lcc} 
& $\begin{array}{c}\text { Mild Gasification } \\
\text { (Test MG-25) }\end{array}$ & Coke Oven \\
\cline { 2 - 2 } & & \\
Biphenyl & 0.049 & 0.378 \\
Acenaphthene & 0.055 & 1.152 \\
Fluorene & 0.128 & 2.304 \\
Phenanthrene/Anthracene & 0.315 & 2.583 \\
2-Methylphenanthrene & 0.398 & 0.630 \\
l-Methylphenanthrene & 0.306 & 0.675 \\
Fluoranthene & 0.015 & 0.478 \\
Pyrene & 0.070 & 0.468 \\
Benz(a)anthracene & 0.091 & 0.274 \\
Chrysene/Triphenylene & 0.000 & 0.199 \\
Benzo(b, k)fluoranthene & 0.000 & 0.319 \\
Benzo(a)pyrene & 0.079 & 0.264 \\
Dibenzo(a,h)anthracere & 0.044 & 0.035 \\
Benzo(g,h,i)perylene & 0.000 & 0.154
\end{tabular}

Table 6. TEST MG-11 $\left(1390^{\circ} \mathrm{F}\right)$ MATERIAL BALANCE

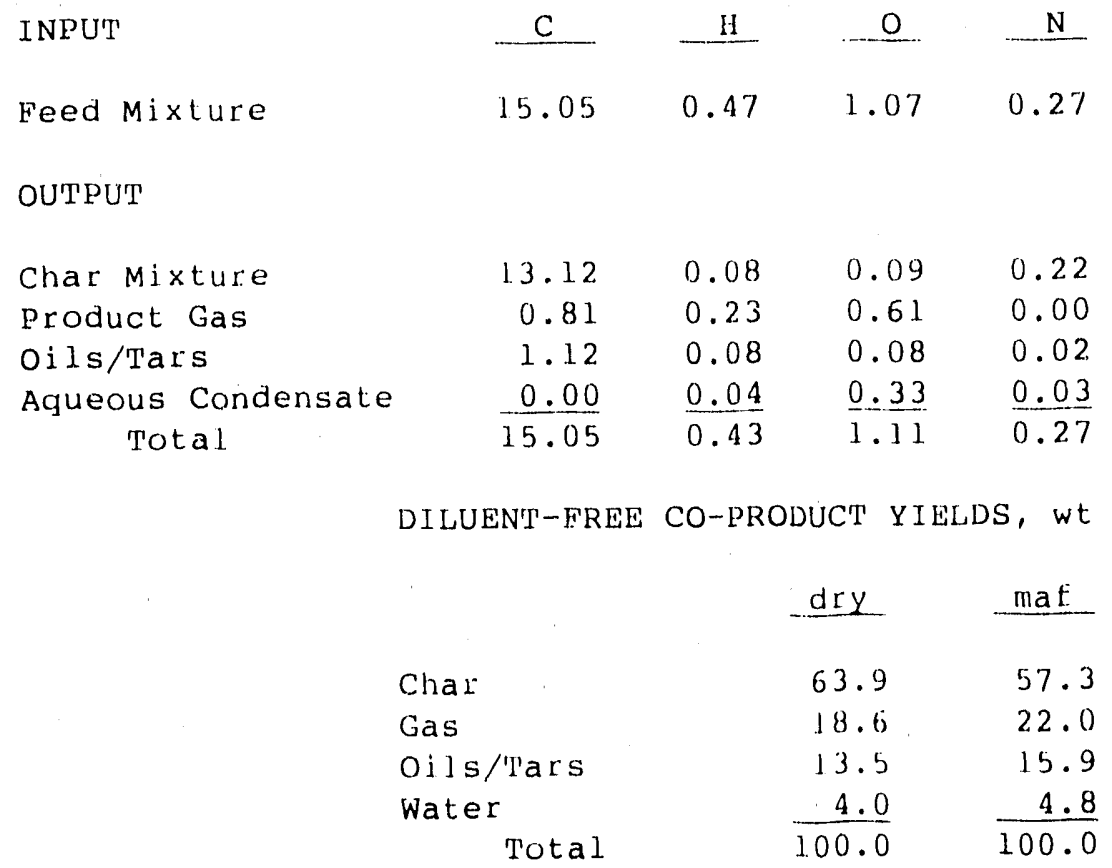




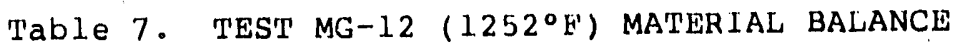

\begin{tabular}{|c|c|c|c|c|c|c|c|}
\hline INPUT & C & $\mathrm{H}$ & 0 & $\mathrm{~N}$ & $\underline{s}$ & Ash & Total \\
\hline Feed Mixture & 8.91 & 0.28 & 0.68 & 0.15 & 0.27 & 1.55 & 11.84 \\
\hline \multicolumn{8}{|l|}{ OUTPUT } \\
\hline Char Mixture & 7.29 & 0.05 & 0.04 & 0.12 & 0.12 & 1.54 & 9.16 \\
\hline Product Gas & 0.34 & 0.10 & 0.21 & 0.00 & 0.11 & -- & 0.76 \\
\hline Oils/Tars & 1.28 & 0.11 & 0.24 & 0.02 & 0.03 & 0.01 & 1.68 \\
\hline Aqueous Condensate & 0.00 & 0.03 & 0.20 & 0.01 & 0.00 & -- & 0.24 \\
\hline Total & $\overline{8.91}$ & 0.28 & 0.69 & 0.15 & 0.26 & 1.55 & 11.84 \\
\hline t/In & 1.00 & 0.98 & 1.01 & 1.00 & 1.00 & 1.00 & 1.00 \\
\hline
\end{tabular}

DILUENT-FREE CO-PROLJCT YIELDS, wt \& COal

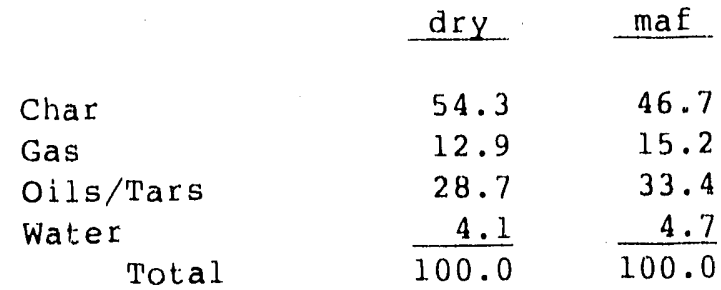

Table 8. TEST MG-14 $\left(1084^{\circ} \mathrm{F}\right)$ MATERIAL BALANCE

\begin{tabular}{|c|c|c|c|c|c|c|c|}
\hline INPUT & C & $\mathrm{H}$ & $\mathrm{O}$ & $\mathrm{N}$ & $\mathrm{s}$ & Ash & Total \\
\hline Feed Mixture & 15.45 & 0.49 & 1.24 & 0.24 & 0.47 & 2.87 & 20.76 \\
\hline \multicolumn{8}{|l|}{ OUTPUT } \\
\hline C'lar Mixture & 13.45 & 0.13 & 0.41 & 0.21 & 0.26 & 2.87 & 17.33 \\
\hline Product Gas & 0.41 & 0.12 & 0.21 & 0.00 & 0.17 & -- & 0.91 \\
\hline Oils/Tars & 1.59 & 0.14 & 0.24 & 0.02 & 0.04 & 0.00 & 2.03 \\
\hline Aqueous Condensate & 0.00 & $\underline{0.05}$ & $\underline{0.43}$ & $\underline{0.01}$ & $\underline{0.00}$ & -- & 0.49 \\
\hline Total & $\overline{15.45}$ & $\overline{0.44}$ & $\overline{1.29}$ & $\overline{0.24}$ & 0.47 & 2.87 & 20.76 \\
\hline Out/In & 1.00 & 0.90 & 1.04 & 1.00 & 1.00 & 1.00 & 1.00 \\
\hline
\end{tabular}
DILUENT-FREE CO-PRODUCT YIELDS, wt. \& COal

\begin{tabular}{lrr} 
& \multicolumn{1}{c}{ dry } & maf \\
\cline { 2 - 2 } Char & 66.6 & 60.2 \\
Gas & 8.8 & 10.5 \\
Oils/Tars & 19.9 & 23.6 \\
Water Total & $\frac{4.7}{100.0}$ & $\frac{5.7}{100.0}$
\end{tabular}


Table 9. TEST MG-15 (1034ㄷ) MATERIAL BALANCE

\begin{tabular}{|c|c|c|c|c|c|c|c|}
\hline INPUT & $C$ & $\mathrm{H}$ & 0 & $\mathrm{~N}$ & $S$ & Ash & Total \\
\hline Feed Mixture & 14.63 & 0.45 & 1.00 & 0.26 & 0.37 & 2.39 & 19.1 \\
\hline \multicolumn{8}{|l|}{ OUTPUT } \\
\hline Char Mixture & 12.64 & 0.13 & 0.30 & 0.22 & 0.22 & 2.38 & 15.89 \\
\hline Product Gas & 0.41 & 0.11 & 0.25 & 0.00 & 0.12 & -- & 0.89 \\
\hline Oils/Tars & 1.58 & 0.15 & 0.34 & 0.02 & 0.03 & 0.01 & 2.13 \\
\hline Aqueous Condensate & 0.00 & 0.02 & 0.16 & 0.02 & 0.00 & - & 0.20 \\
\hline Total & 14.63 & 0.41 & 1.05 & 0.26 & 0.37 & 2.39 & 19.11 \\
\hline out/In & 1.00 & 0.90 & 1.05 & 1.00 & 1.00 & 1.00 & \\
\hline
\end{tabular}

DILUENT-FREE CO-PRODUCT YIELDS, wt $\&$ COal

\begin{tabular}{lrr} 
& \multicolumn{1}{c}{ dry } & maf \\
\cline { 2 - 3 } Char & 66.0 & 60.9 \\
Gas & 9.4 & 10.9 \\
Oils/Tars & 22.4 & 25.8 \\
Water & $\frac{2.2}{100.0}$ & $\frac{2.4}{100.0}$
\end{tabular}

Table 10. TEST MG-16 $\left(1183^{\circ} \mathrm{F}\right)$ MATERIAL BALANCE

\begin{tabular}{|c|c|c|c|c|c|c|c|}
\hline INPUT & $C$ & $\mathrm{H}$ & 0 & $\mathrm{~N}$ & $s$ & Ash & Total. \\
\hline Feed Mixture & 23.59 & 0.69 & 1.92 & 0.40 & 0.68 & 4.39 & 31.67 \\
\hline \multicolumn{8}{|l|}{ OUTPUT' } \\
\hline Char Mixture & 20.52 & 0.12 & 0.43 & 0.31 & 0.33 & 4.38 & 26.09 \\
\hline Product Gas & 0.67 & 0.19 & 0.37 & 0.00 & 0.30 & - & 1.53 \\
\hline Oils/Tars & 2.40 & 0.22 & 0.52 & 0.02 & 0.05 & 0.01 & 3.22 \\
\hline Aqueous Condensate & 0.00 & $\underline{0.09}$ & $\underline{0.67}$ & $\underline{0.07}$ & $\underline{0.00}$ & -- & 0.83 \\
\hline Total & 23.59 & 0.62 & 1.99 & 0.40 & 0.68 & 4.39 & 31.67 \\
\hline Out/In & 1.00 & 0.90 & 1.05 & 1.00 & 1.00 & 1.00 & 1.00 \\
\hline
\end{tabular}

DILUENT-FREE CO-PRODUCT YIELDS, wt \& COal

\begin{tabular}{|c|c|c|}
\hline & dry & $\operatorname{maf}$ \\
\hline Char & 64.3 & 57.5 \\
\hline Gas & 9.8 & 11.7 \\
\hline Oils/Tars & 20.6 & 24.5 \\
\hline Water & 5.3 & 6.3 \\
\hline Total & $\overline{100.0}$ & $\overline{100.0}$ \\
\hline
\end{tabular}


Table 11. TEST MG-19 $\left(1102^{\circ} \mathrm{F}\right)$ MATERIAL BALANCE

\begin{tabular}{|c|c|c|c|c|c|c|c|}
\hline INPUT & $\mathrm{C}$ & $\mathrm{H}$ & 0 & $\mathrm{~N}$ & $\mathrm{~S}$ & Ash & Total \\
\hline Feed Mixture & 67.26 & 2.12 & 3.73 & 1.21 & 1.78 & 11.05 & 87.15 \\
\hline \multicolumn{8}{|l|}{ OUTPU'T } \\
\hline Char Mixture & 57.14 & 0.67 & 1.04 & 1.02 & 1.12 & 11.05 & 72.04 \\
\hline Product Gas & 1.40 & 0.36 & 0.59 & 0.00 & 0.45 & -- & 2.8 \\
\hline Oils/Tars & 8.72 & 0.79 & 1.35 & 0.10 & 0.21 & 0.00 & 1.1 .17 \\
\hline Aqueous Condensate & 0.00 & $\underline{0.12}$ & 0.95 & 0.09 & 0.00 & - & 1.16 \\
\hline Total & $\overline{67.26}$ & $\overline{1.94}$ & 3.93 & $\overline{1.21}$ & $\overline{1.78}$ & $\overline{11.05}$ & $\overline{87.17}$ \\
\hline Out/In & 1.00 & 0.92 & 1.05 & 1.00 & 1.00 & 1.00 & 1.00 \\
\hline
\end{tabular}

DILUENT-FREE CO-PRODUCT YIELIDS, wt \& COal

\begin{tabular}{lrr} 
& \multicolumn{1}{c}{ dry } & maf \\
Char & & \\
Gas & 64.2 & 58.5 \\
Oils/Tars & 6.6 & 7.7 \\
Water & 26.4 & 30.7 \\
$\quad$ Total & $\frac{2.8}{100.0}$ & $\frac{3.1}{100.0}$
\end{tabular}

Table 3 shows a comparison of selected polyaromatic hydrocarbons in the tar from Test MG-25 (process temperature of $1130^{\circ} \mathrm{F}$ ) with a typical coke oven tar. As seen, the mild gasification tar contains at least an order of magnitude less of these compounds, many of which are environmentally sensitive, compared to conventional coke oven tar.

In Table 4, a comparison of the co-product yields from mild gasification at $1183^{\circ} \mathrm{F}$ with by-product yields from a typical coking process shows the major expected difference in the yields of oils/tars. Combining the values in Tables 3 and 4 reveal that the absolute quantities of environmentally sensitive PAH compounds, as well as their percentages in the total liquids, are lower in the mild gasification oils/tars. This is shown in Table 5, with PAH compounds expressed as pounds per ton of dry coal. Figure 8 shows the ash and volatile matter content of the mild gasification char with process temperature. These data verify the increasing devolatilization and carbon conversion of the feed cocil as the mild gasification temperature increases.

Gas composition is also affected by the process temperature as is shown in Figure 9. The dry, nitrogen-free concentrations of hydrogen and carbon 
monoxide increase with temperature, whereas carbon dioxide and hydrocarbon gases decrease. These trends are consistent with well-known devolatilization and gas-phase equilibrium data. The hydrogen sulfide content of the gas also decreases with temperature, and it appears that, even when the increased gas yield at higher temperature is taken into account, the amount of sulfur released as hydrogen sulfide decreases with temperature.

\section{Material Balances for the PRU Tests}

The material balances are presented in Tables 6 through 11 for mild gasification T'ests MG-11, 12, 14, 15, 16, and 19. These balances have been adjusted to provide the data values of each test on a consistent basis for comparison. The raw material balances are presented in Appendix A. The major measurable streams of carbon and ash were usually better than 908 in balance. The data adjustment procedure that was applied is summarized as follows:

- The ash was balanced by adjusting the amount of fluidized bed char collected during the test.

- The carbon was balanced by adjusting the amount of oils and tars collected by solvent washing, assuming that the heavy components coating pipes are difficult to collect and also the sintered metal filter used to separate char from the gas stream provides an active surface that promotes the coking of a portion of the heavier tars.

- Sulfur wis balanced by assuming that unaccounted sulfur is present as hydroger, sulfide in the gases, part of which may have been absorbed by stainless steel components in the system.

- Nitrogen from the coal that is not accounted for in the analyses was assumed to form animonia in the aqueous condensate stream.

- Finally, diluent-free co-product yields were calculated, assuming that the diluent coke does not react significantly with nitrogen and steam, and the co-product yields were forced to 1008 by adjusting the chemical water make.

This procedure leaves hydrogen and oxygen out of balance, generally by a few percent. No attempts were made to balance oxygen because tinis element is determined by the difference in solids and oil elemental analyses, and thus can be affected by accumulated uncertainties (error limits) in measurement of the other elements. 
Task 3. Bench-Scale Char Upgrading Study

The char upgrading study with the chars from the test coals in the PRU tests were evaluated in terms of three major char products. Three solid coproducts were ldentified as probable value-added products in the Task 1 topical report on the market survey of products from the mild gasification of coal. These solid co-products are: a smokeless fuel containing char mixed with limestone for sulfur retention, an activated adsorbent char, and a formcoke for blast furnaces in steelmaking.

The work in this quarter completed the upgrading and property evaluation tests for the smokeless fuel and the activated adsorbent co-products, and began evaluation of formcoke from the test coals. F'urther work in the test will focus only on the formooke char product.

As reported in the last quarter, briquettes made from the chars of the test coals were made under a variety of forming conditions of temperature and pressure, using either pitch or a small amount of raw coal as a binder. These were subjected to a curing step after forming, either soaking at a temperature at $400^{\circ} \mathrm{F}$ in air for the smokeless fuel briquettes, or in a nitrogen atmosphere at $1800^{\circ} \mathrm{F}$ for the formcoke briquettes.

The smokeless fuel briquettes were prepared with the addition of limestone for sulfur retention upon combustion. A 2:1 calcium-to-sulfur mole ratio was blended in the briquette. T'he briquettes were combusted in a small pile and the residues from the top of the pile and from the center of the pile were analyzed for sulfur retention as calcium sulfate and for other sulfur forms present. Figure 10 shows the various sulfur forms and retention before and after combustion, with 84 and 888 of the sulfur retained in the ash from the center and top of the pile, respectively. Table 12 compares the heating value of the limestone-containing smokeless fuel briquette to the heating value of other solid fuels. The heating value of the smokeless fuel compares favorably with common domestic solid fuels.

The potential for adsorbent char carbon was explored by activating a number of Illinois No. 6 coal char samples with steam and measuring the adsorbent properties. Chars from the PRU tests and from a 2-inch batch fluidization test apparatus were used. The summary of the chars and their measured properties are presented in Table 13. Figure 11 shows the measured 


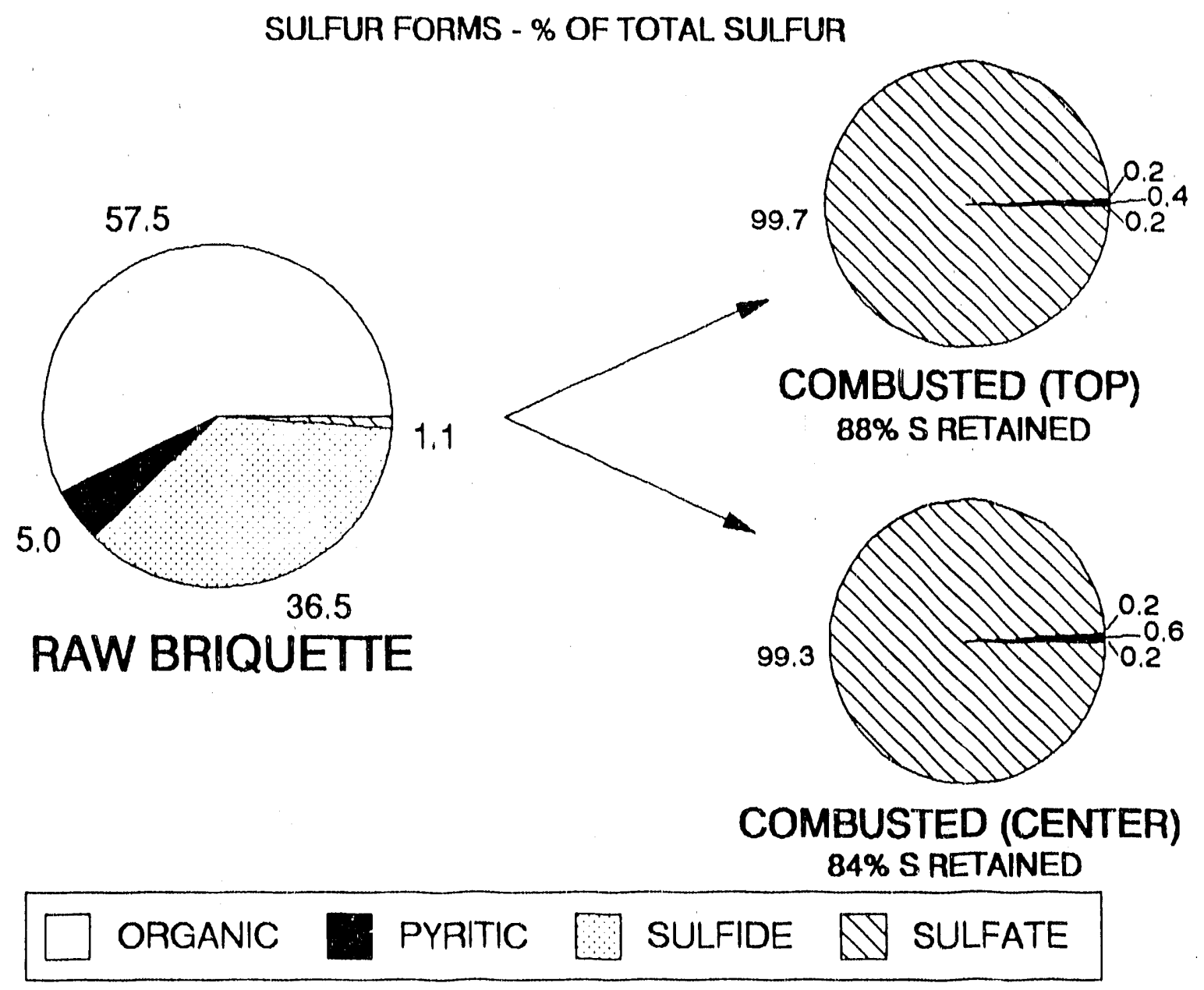

Figure 10. SULFUR FORMS IN COMBUSTED SMOKELESS FUEL 


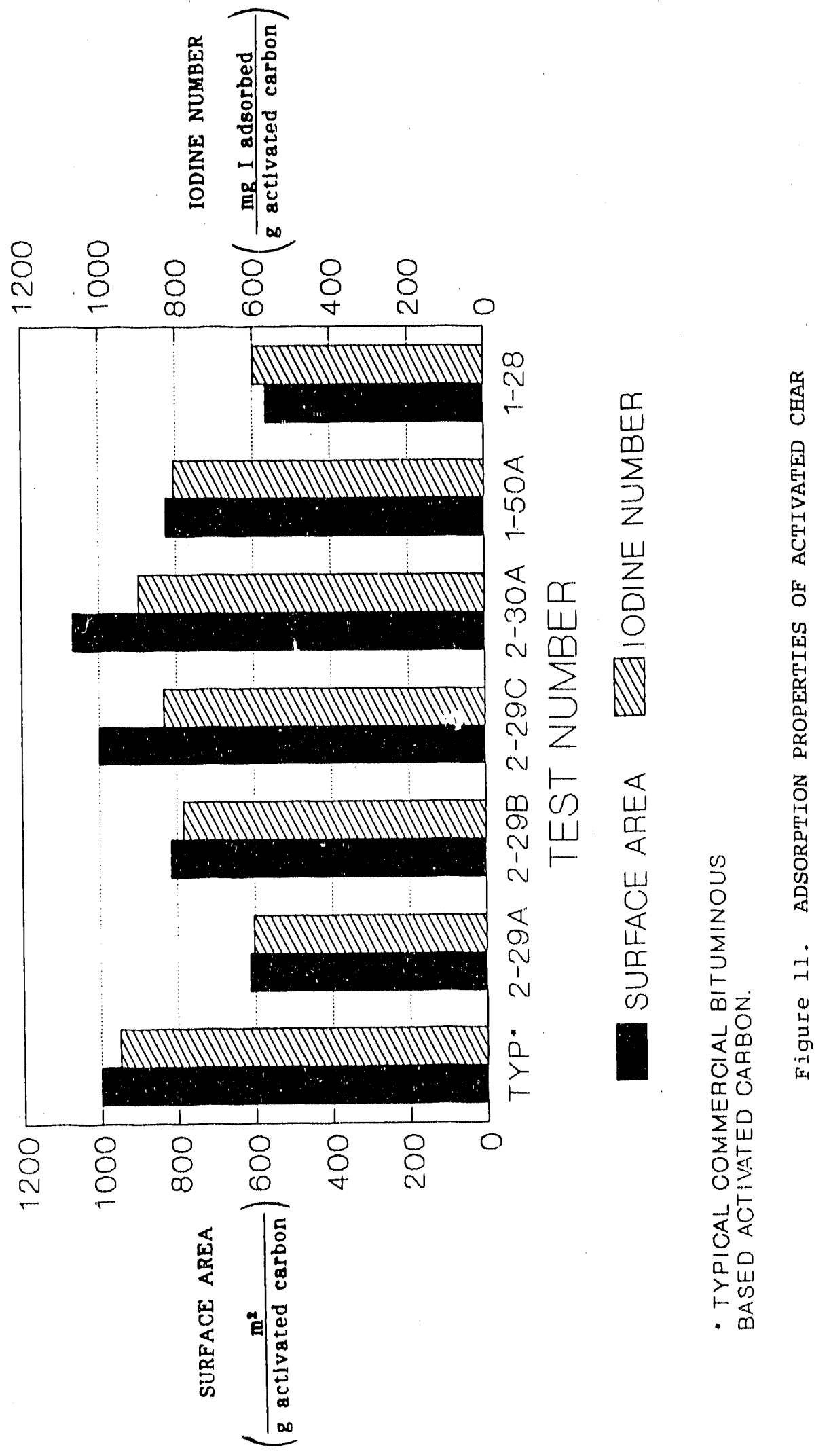


T'able 12. HEATING VALUE COMPARISON OF SMOKELESS F'JEL WITH DOMESTIC FUELS

Heating Value
(milition Btu/ton)

Wood ( 158 molsture)

Utility Bituminous coal

Anthracite*

Charcoal Briquettes

Smokeless Fuel with limestone

* Anthracite imported into Korea.
14.6

21.1

21.6

30.0

20.0

values for surface area and for an lodine adsorption test used to evaluate adsorbent carbon (ASTM I'est D4607-86). These values compare favorably with values for a typical commerclal bituminous-coal-based activated carbon.

The duration of steam activation at $1800^{\circ} \mathrm{F}$ was varied from 45 to 180 minutes, using char from the same sample, to evaluate the degree of activation. Figure 12 shows the increased values of surface area and lodine number as the duration of activation increases; however, at the same time, the amount of activated carbon available decreases as the duration of steam activation increases, as shown in Figure 1.3. Iodine numbers and surface area values adjusted for this "carbon burnoff" are shown in Figure 14, where an optimurn carbon burnoff value of about 408 appears when these data are plotted against the amount of carbon burnoff. This shows that going beyond 408 carbon burnoff reduces the effective amount of adsorbent produced.

'The formcoke co-product is considered to be a desirable product in view of declining U.S. coke production. In a meeting of the Industrial project Advisory Group (IPAG) held at IGT, the consensus opinion was that this product should be developed. IPAG is a committee formed with representatives from the steel. industry, the tar processing industry, and technical consultants to review the results of the mild gasification program and suggest marketoriented directions to the program. The committee is chaired by a representative from Peabody Development Company.

The balance of the work in Task 3 concentrated on the formcoke application. Briquettes were made under various conditions and tested for strength. A procedure for a carbon dioxide-carbon reactivity test for coke 


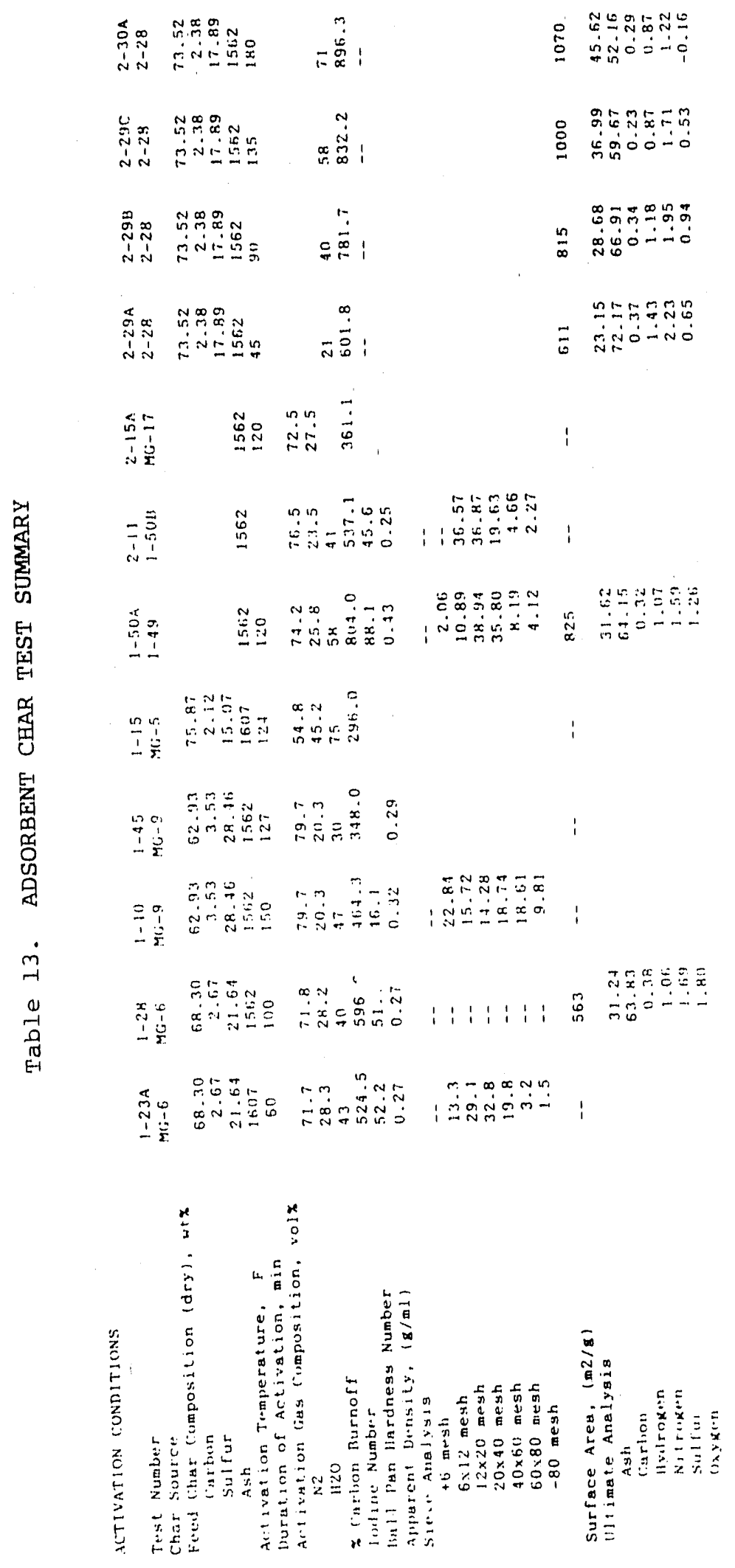

31 


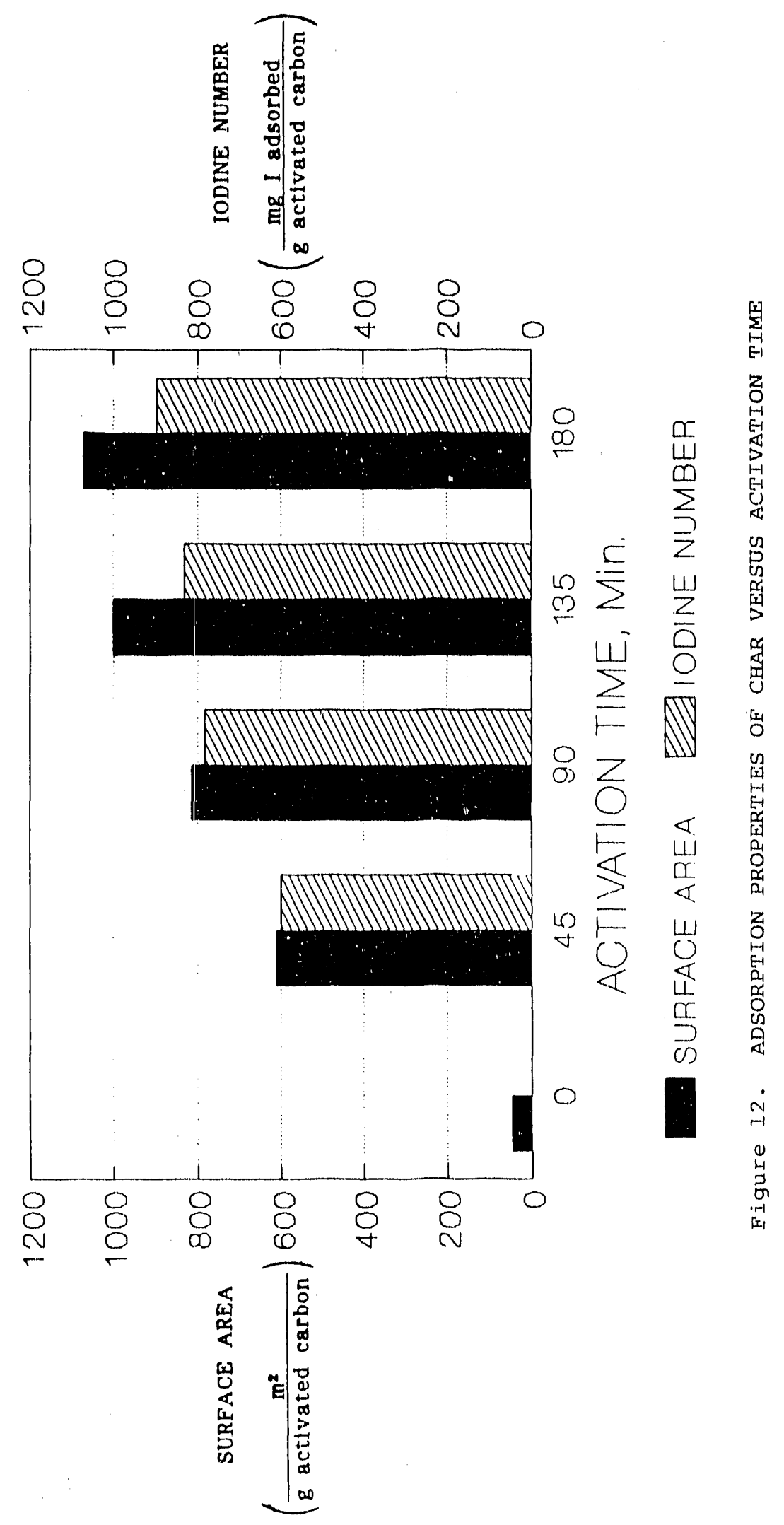




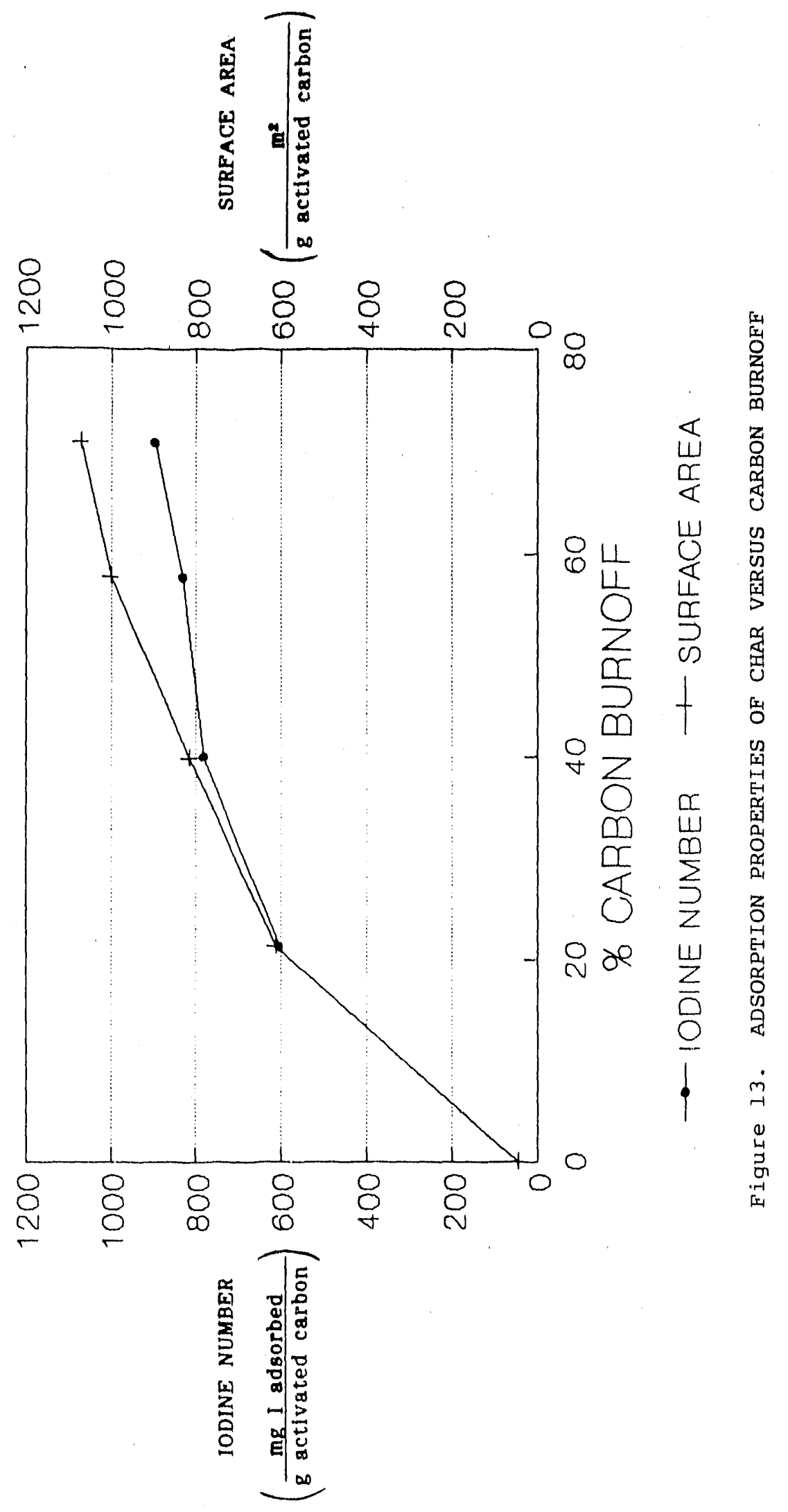

33

$\begin{array}{lllllllll} & \text { I } & S & T & \text { I } & T & U & T & E\end{array}$

O F

G A S

T E C H N O L O 


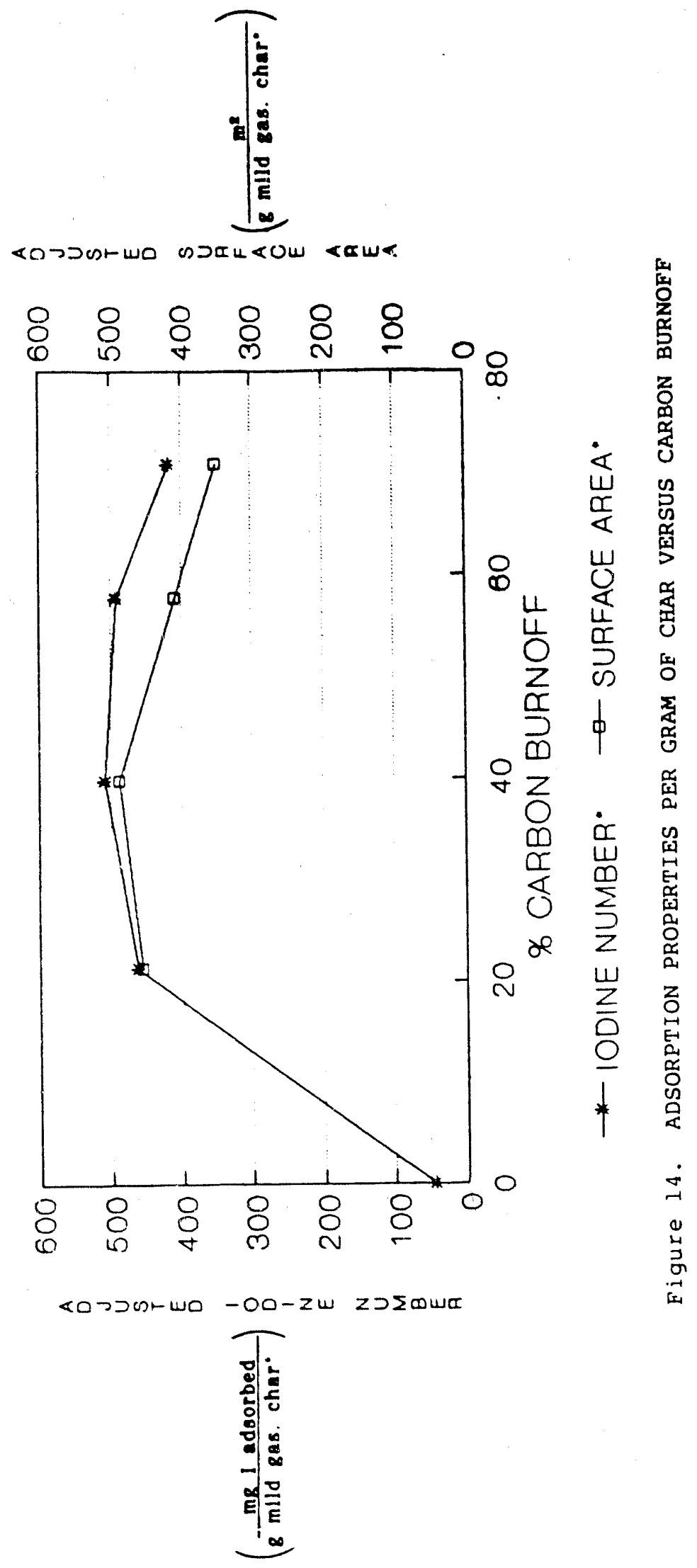


was obtained from Bethlehem Steel Company and applied to the formcoke briquettes.

The physical strength of the formcoke briquettes were measured by the diametral compression test (ASTM Test B485-76), which measures the tensile strength up to fracture. The range of tensile strengths obtained for the samples are shown in Figure 15. This figure shcws that the strength of briquettes from a mild gasification char could be made comparable to the available commercial coke. Work on briquette testing is continuing with chars from the West Virginia coal.

The coke reactivity test adapted from the Bethlehem procedure was calibrated with a sample of coke obtained from Inland steel Company. The result is shown in Figure 16 along with data from a sample formcoke made from the West Virginia char. The Inland coke value is consistent with expectations from its description as a low reactivity coke. The West Virginia coke reactivity falls near the middle of a range of values for all types of coke. One of the uses of this test is to define the reactivity values of available cokes so that the blending of different coals can produce the desired coke properties.

Task 4. System Integration Studies

The work scope for Task 4 includes the installation and operation of a total condensate collection system for the PRU and a conceptual process design for a 24 ton per day (TPD) process development unit (PDU).

The total condensate collection system to be installed is shown schematically in Figure 17. It consists of a quench vessel with recirculated quench water that is cooled in a water-jacketed heat exchanger. The condensate system can be activated after steady-state conditions have been achieved by operation of three hot-service diversion valves installed in the pipeline upstream of the pressure letdown station. The fabricated quench vessel is scheduled to be delivered in January, and installation of the vessel and other equipment, pipe welding, and electrical work will begin immediately thereafter. Shakedown is expected to be completed by the end of February.

The process design for the 24 TPD PDU by Bechtel National, Inc. is nearing completion. The PDU design will be site-specific for installation at the Illinois Coal Development Park in Carterville, Illinois, operated by 


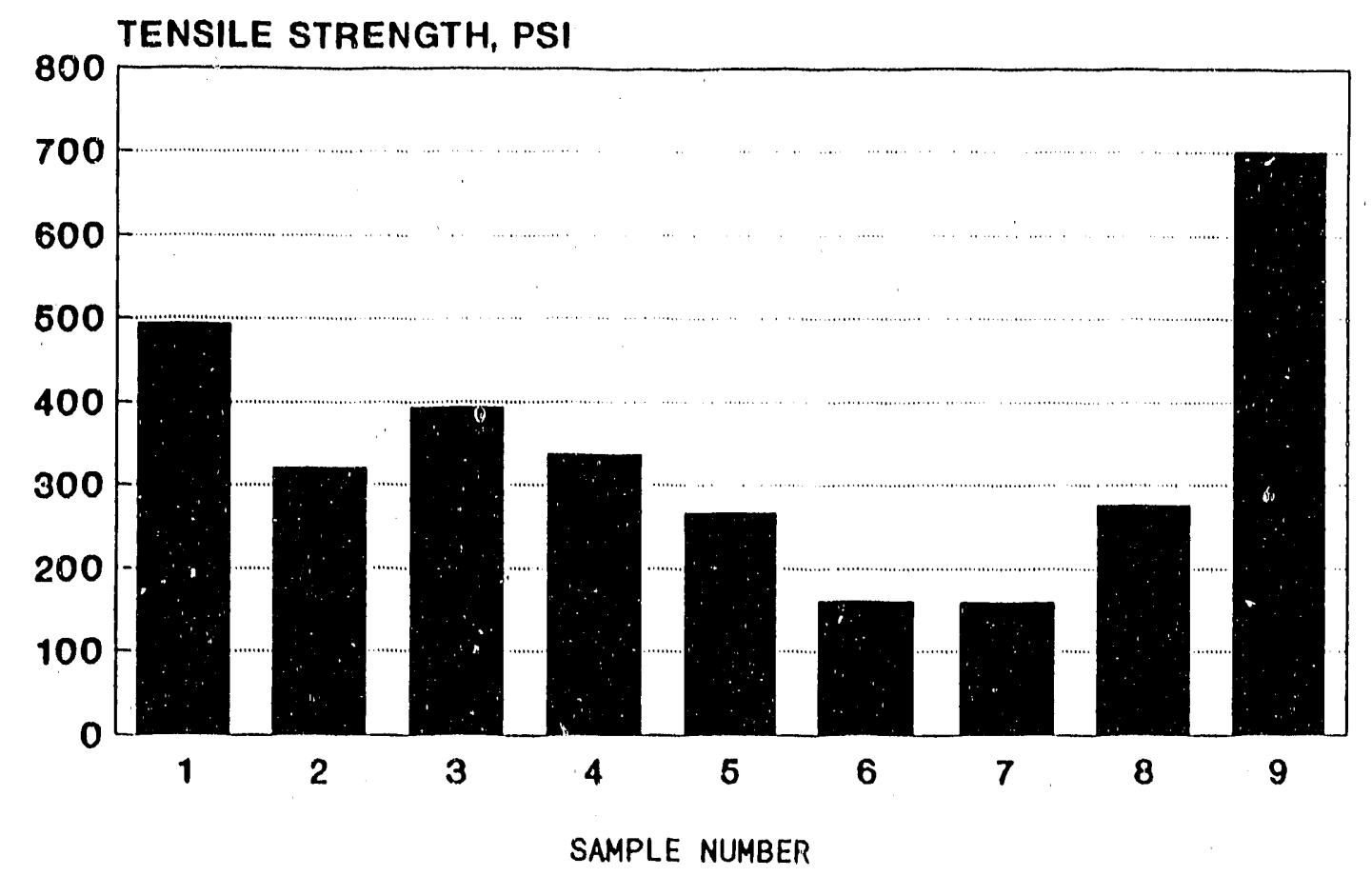

SAMPLE NO.

\begin{tabular}{|c|c|c|}
\hline COMMERCIAL COK & CE A* & -- \\
\hline COMMERCIAL COK & $\angle E B^{*}$ & -- \\
\hline FOUNDRY COKE* & & $\ldots$ \\
\hline HOT BRIQUETTE & 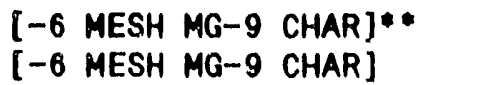 & $\begin{array}{r}4000 \\
10000\end{array}$ \\
\hline HOT BRIQUETTE & 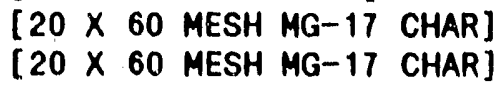 & $\begin{array}{r}4000 \\
10000\end{array}$ \\
\hline $\begin{array}{l}\text { HOT BRIQUETTE } \\
\text { METALLURGICAL }\end{array}$ & $\begin{array}{l}\text { [-20 MESH MG-9 CHAR] } \\
\text { COKE SAMPLE INLAND STEEL }\end{array}$ & 4000 \\
\hline
\end{tabular}

* values from fuel, january 1972, vol. 51

** BRIQUETTES MADE IN 1:1 WEIGHT RATIO OF CHAR AND ILL. NO.6 COAL

Figure 15. DIAMETRAL I'ESTS FOR TENSILE STRENGTH 


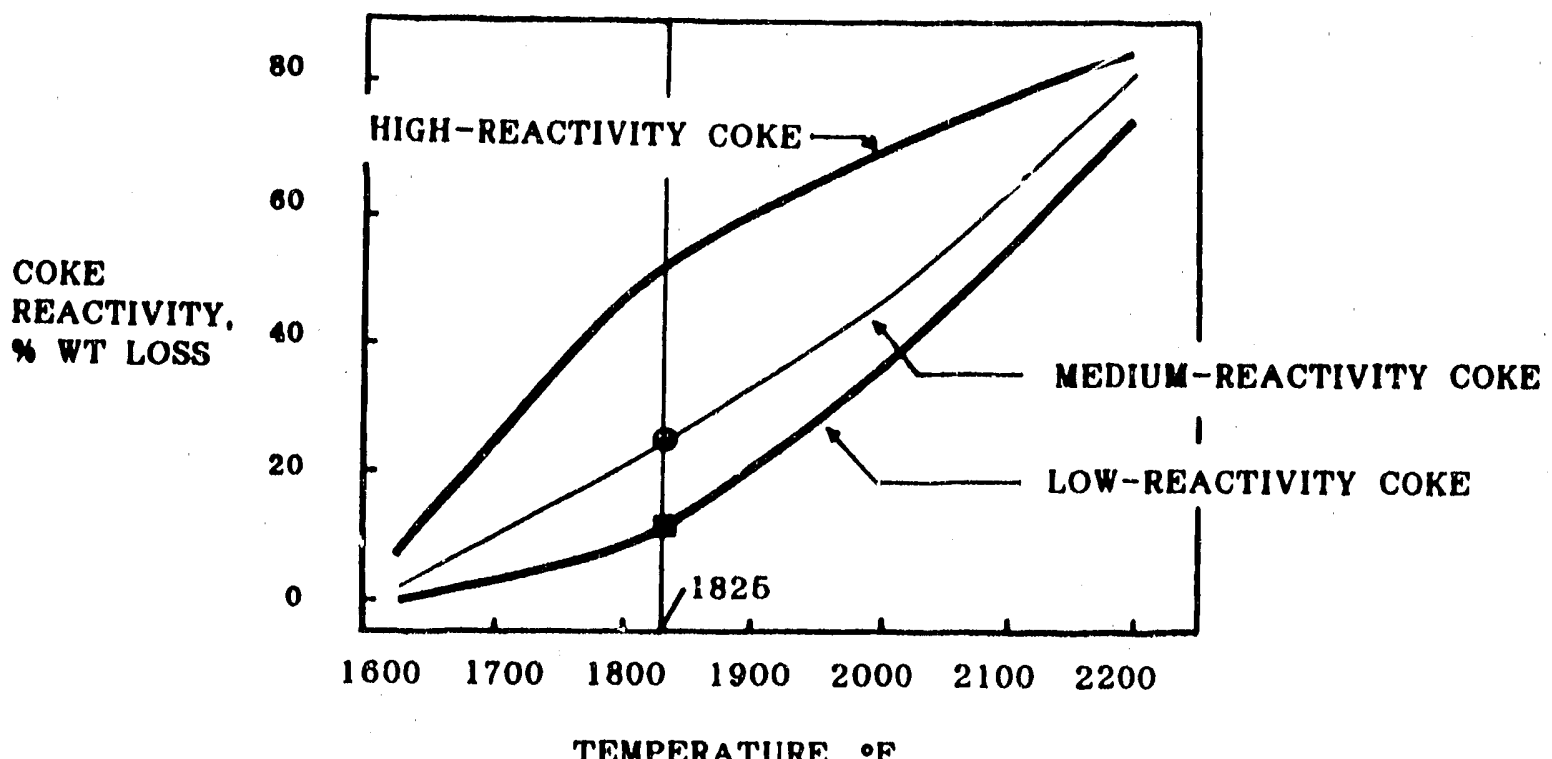

TEMPERATURE, ${ }^{\circ} \mathrm{F}$

- BEThleher $\mathrm{CO}_{2}$ ReACTIVITY test CONDUCTEd ON FORM COKE MADE TROM UV CHAR AND CARBONIZED AT $1800^{\circ} \mathrm{T}$

- COMPARATIVE TEST CONDUCTED MITH CORE SAMPLE OBTAINED FROM INLAND STEEL

Figure 16. FORMCOKE REAC'TIVITY TESTS 


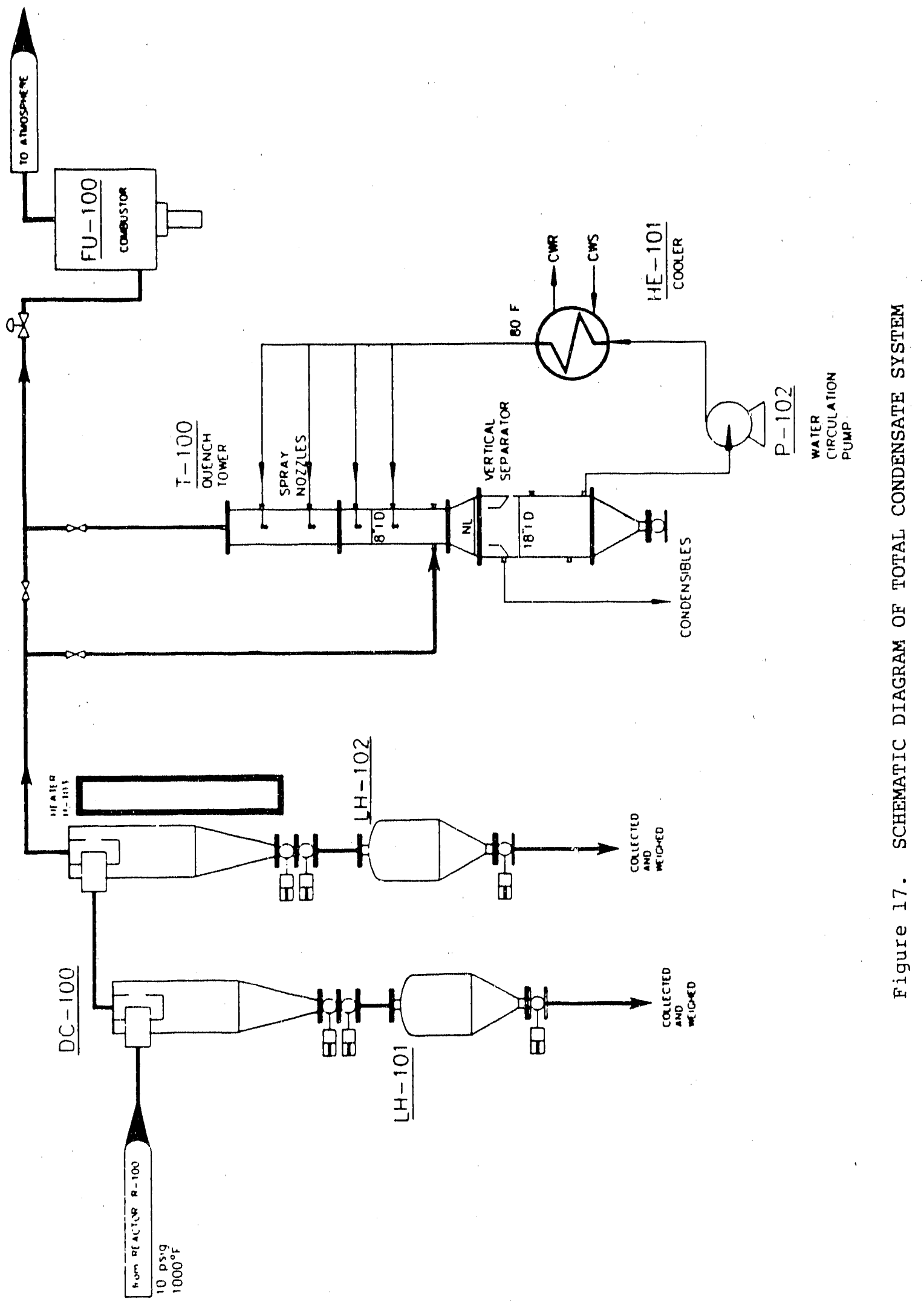
I N S T I T U T E
O F
G A S
T E C H N O L O G Y 
Southern Illinois University at Carbondale. The preliminary process flow diagrams are shown in Figures 18 through 22 and the corresponding material balances for each stream are given in l'ables 14 through 18 . Figure 19 shows two methods to be used in the PDU operation for supplying the heat required by the mild gasification process. One method for heat supply to the gasifier is to heat a portion of the product gas and recycle it to the gasifier; the other method under consideration is to heat a portion of the char and recycle it to the gasifier. The material and energy balances for this process design will be confirmed when the details of the process design are finalized. Following this, an equipment 1 ist and a preliminary capital cost estimate of the pDU will be prepared.

$6 W P / 610890-d / R P P$ 


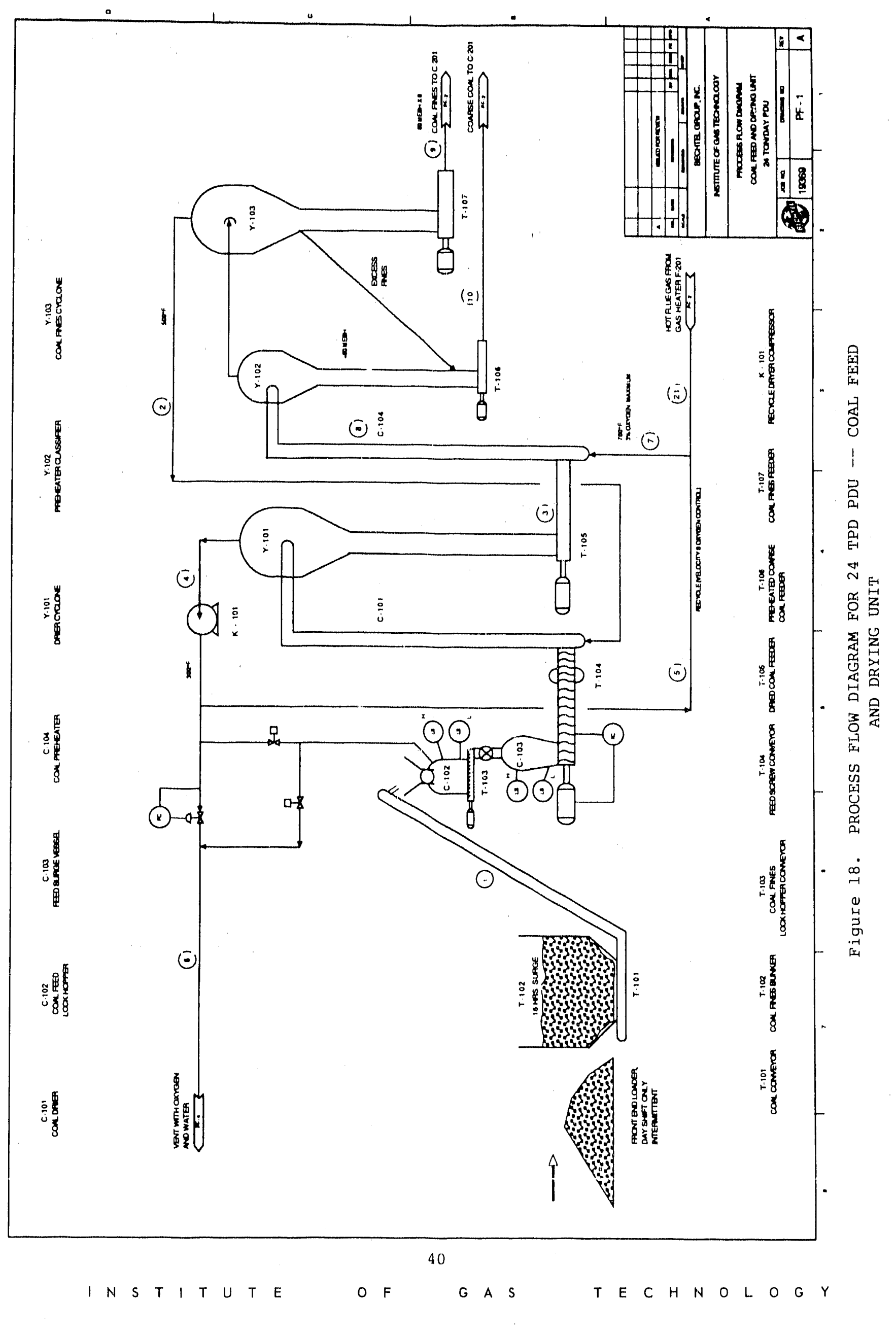




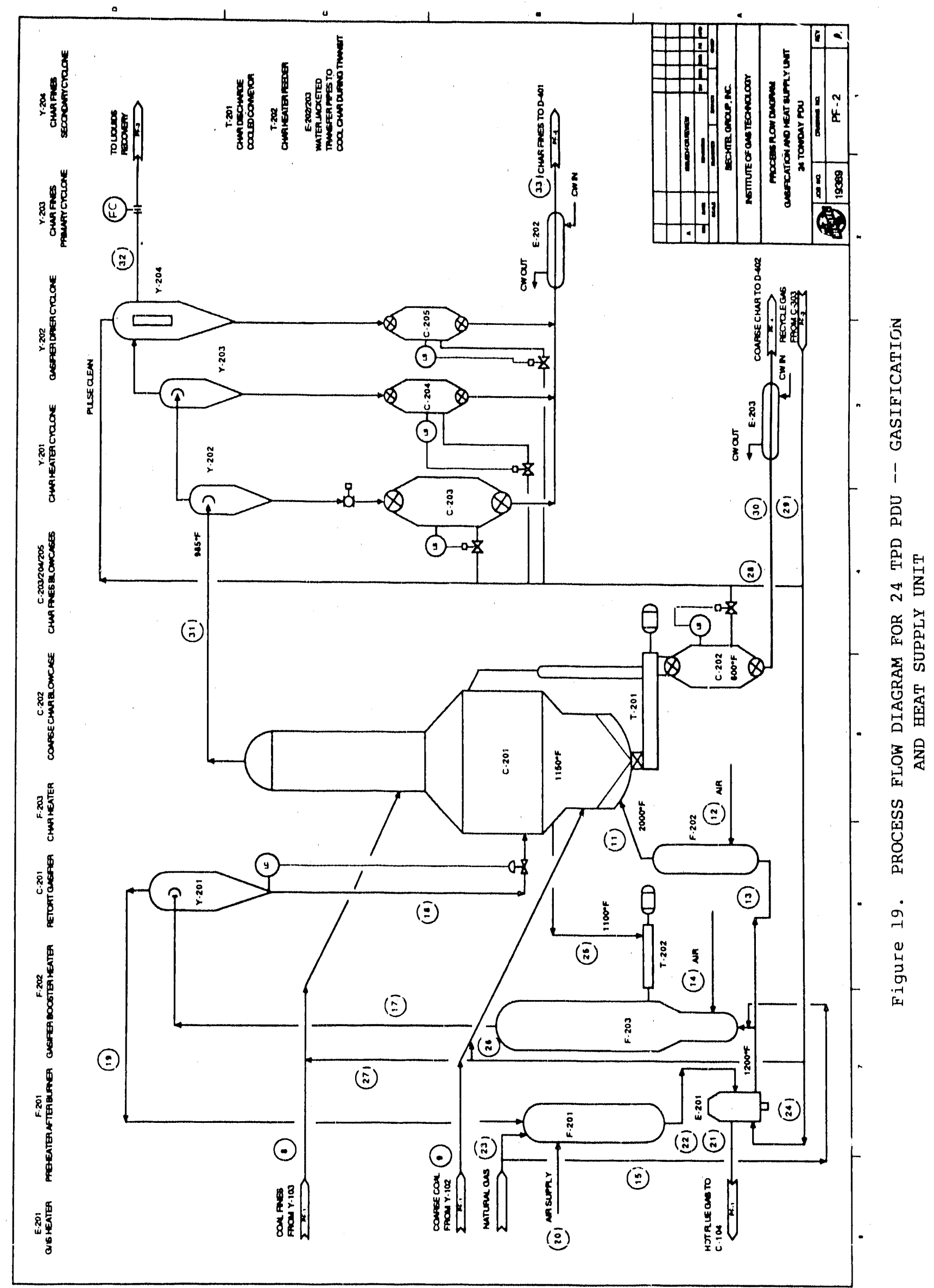

41

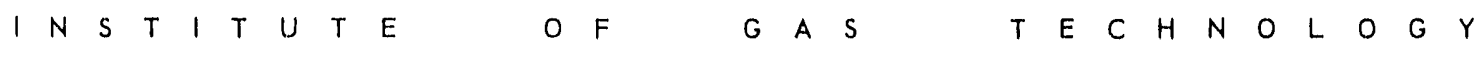




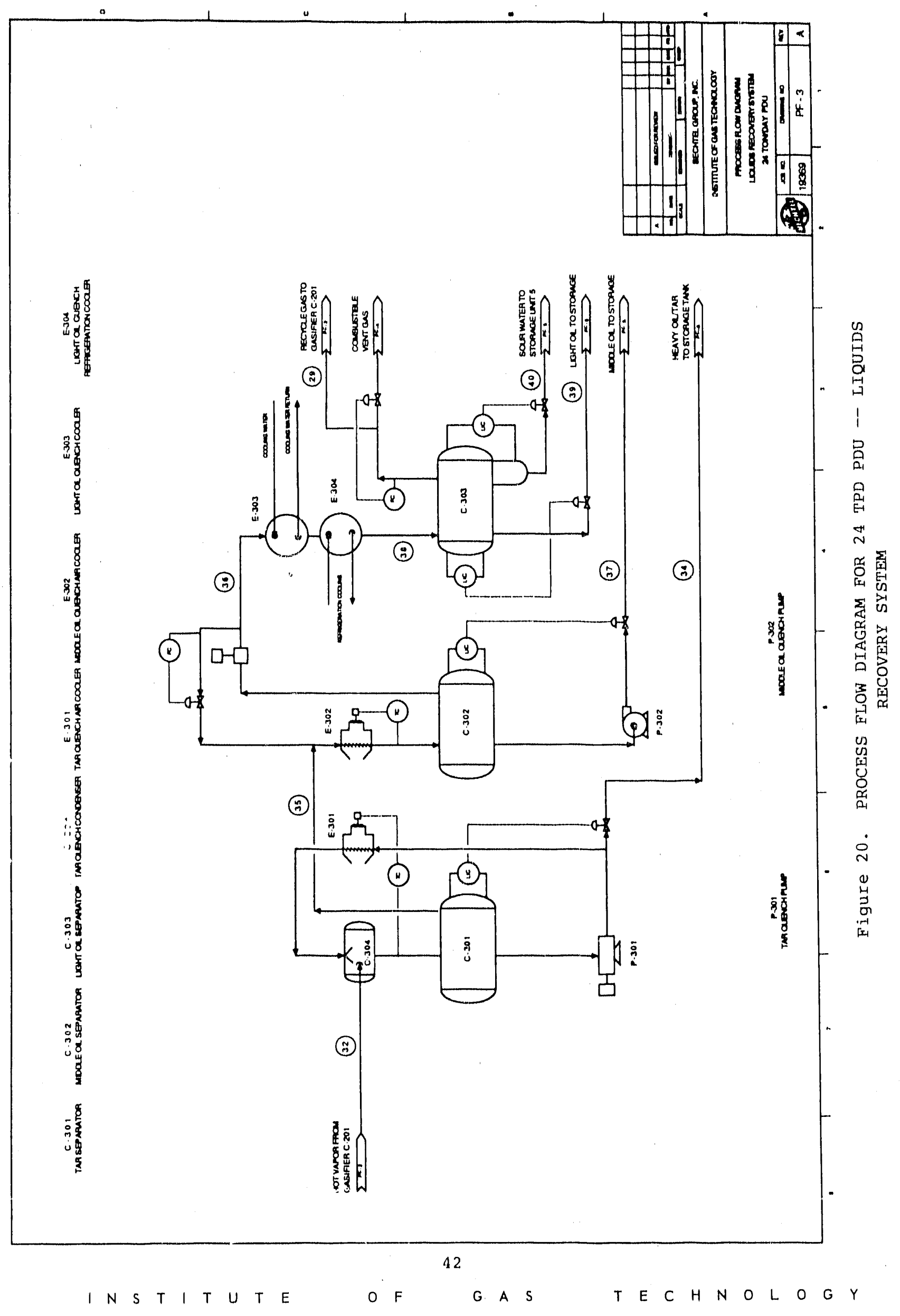




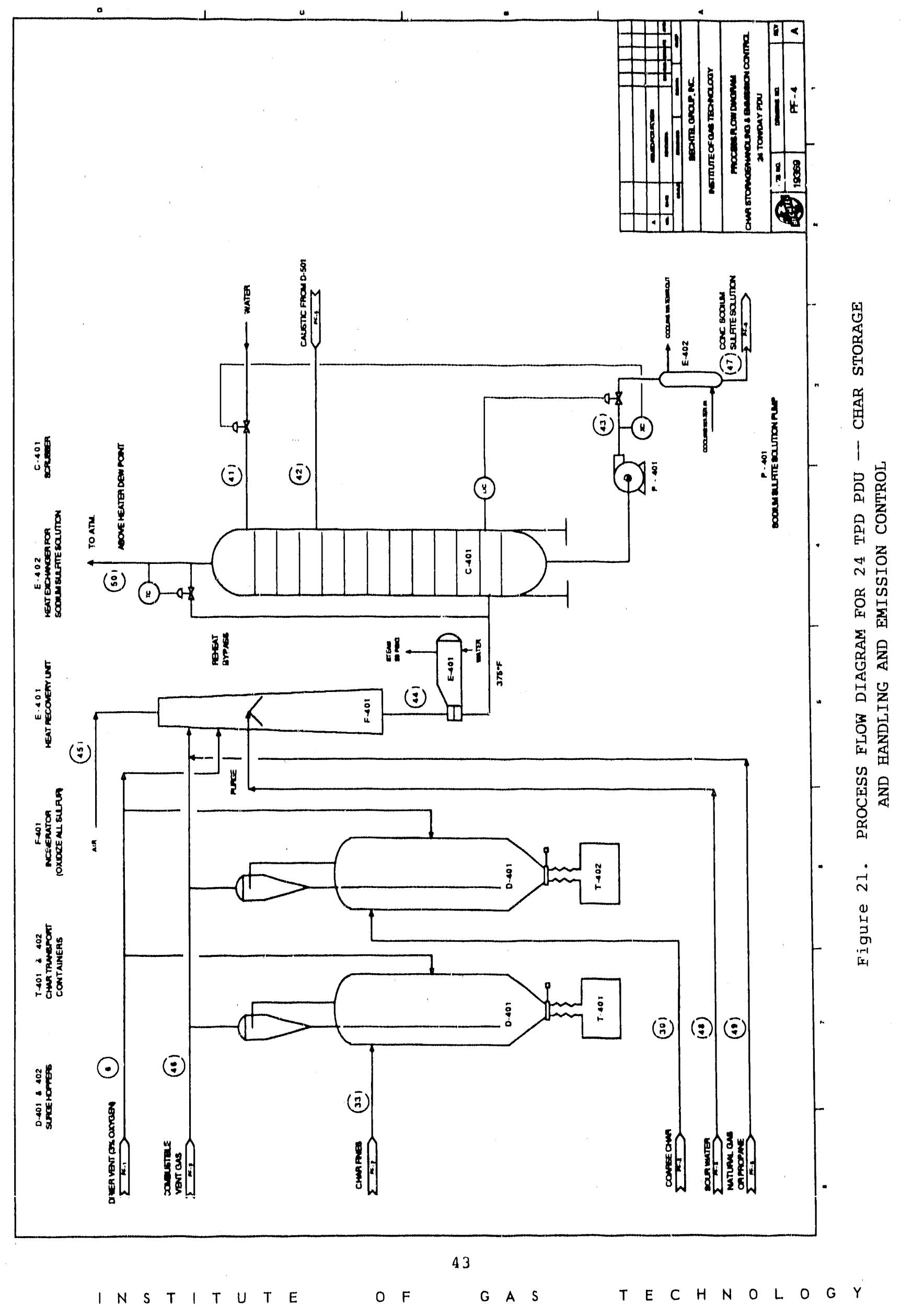




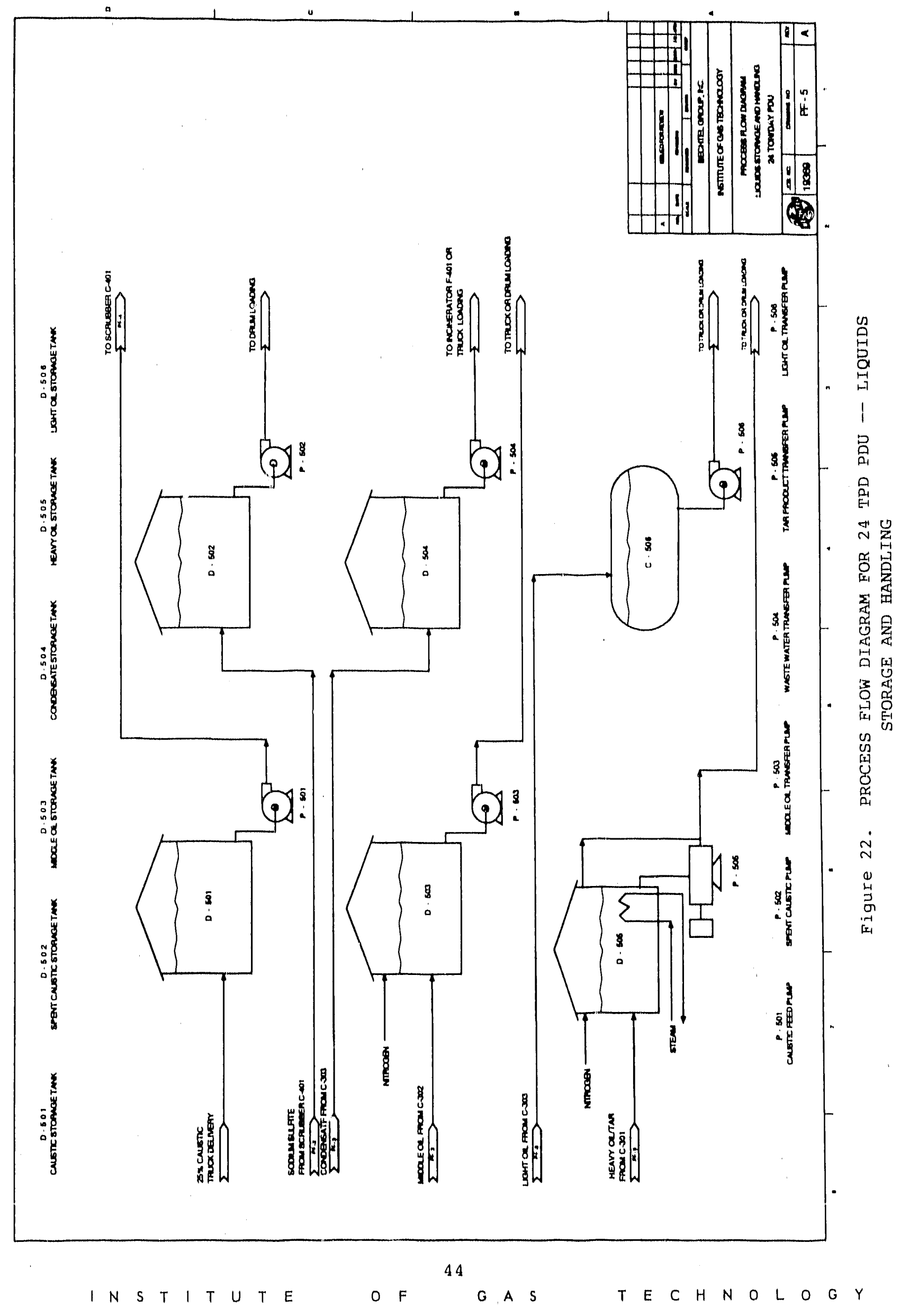




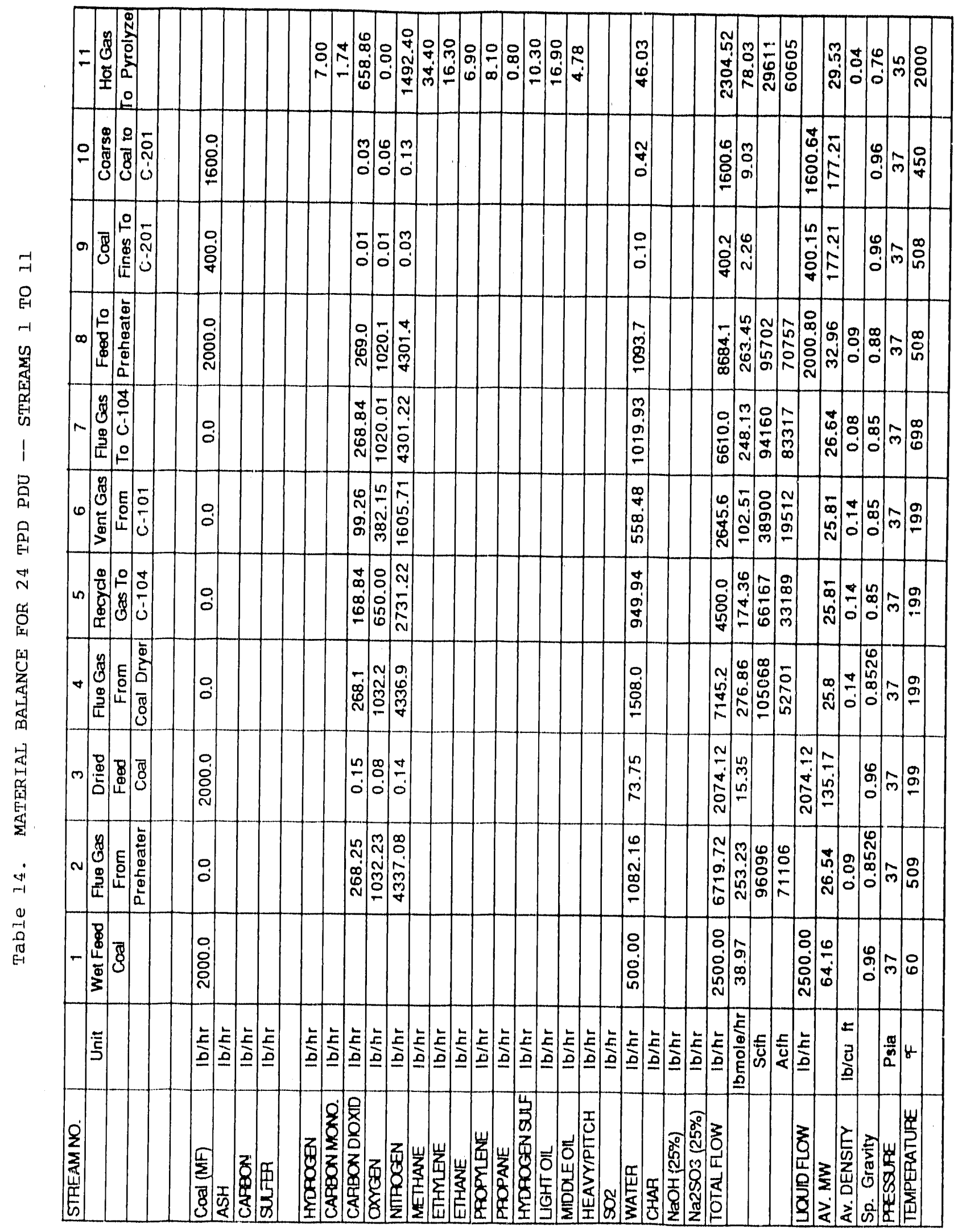




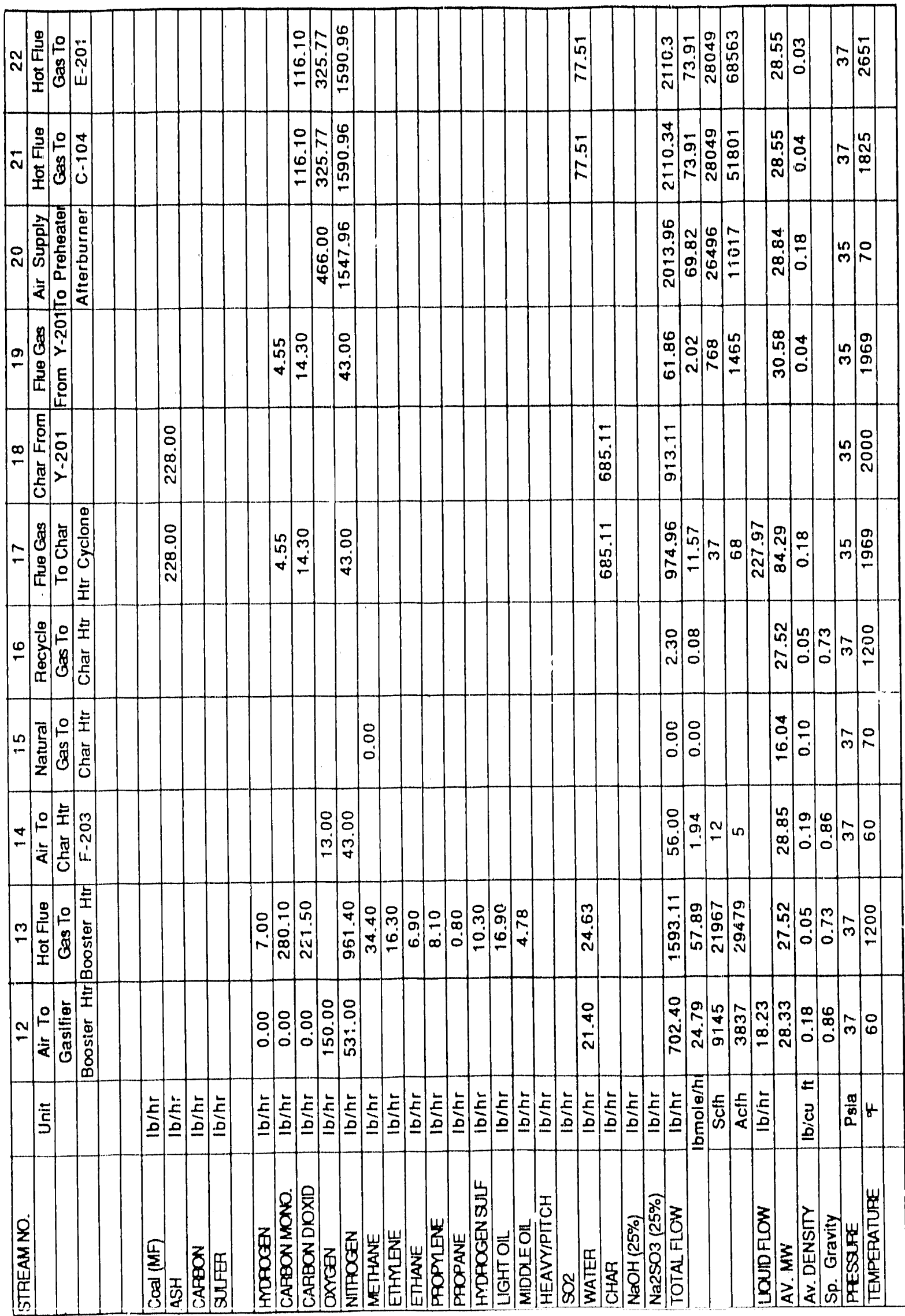




\begin{tabular}{|c|c|c|c|c|c|c|c|c|c|c|c|c|c|c|c|c|c|c|c|c|c|c|c|c|}
\hline$m$ & 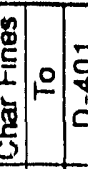 & & & & & & & & & & & & & & & & $\mid \begin{array}{l}0 \\
0 \\
0 \\
0 \\
0 \\
N\end{array}$ & & $\left|\begin{array}{c}0 \\
0 \\
0 \\
0 \\
0 \\
\end{array}\right|$ & م & & $\left|\begin{array}{l}\infty \\
0 \\
0 \\
\sigma \\
\sigma\end{array}\right|$ & & $\min \left|\begin{array}{l}n \\
0 \\
\infty\end{array}\right|$ \\
\hline m & 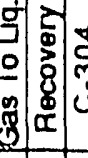 & & & & & 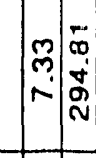 & 究 & \begin{tabular}{l|l}
8 \\
0 \\
0 \\
0 \\
0
\end{tabular} & 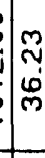 & & & 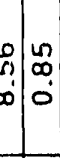 & 임 & 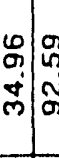 & 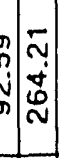 & & 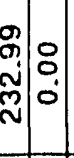 & & 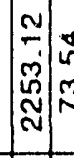 & م & $\mid \begin{array}{l}0 \\
0 \\
0 \\
0 \\
0 \\
m\end{array}$ & $\left|\begin{array}{c}0 \\
0 \\
0 \\
0 \\
0\end{array}\right|$ & 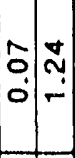 & 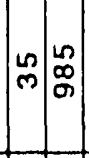 \\
\hline$=$ & 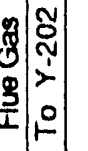 & & & & & 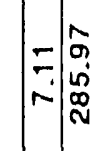 & 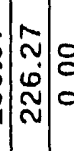 & \begin{tabular}{l|l}
$\dot{0}$ \\
$\vdots$ \\
0 \\
0 \\
0 \\
0 \\
0
\end{tabular} & & & & & \begin{tabular}{|l|} 
\\
0 \\
0 \\
\end{tabular} & $\begin{array}{l}\qquad \\
\dot{m} \\
\dot{m}\end{array}$ & 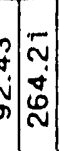 & & 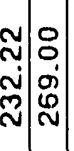 & & 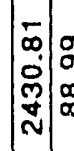 & 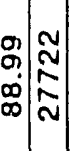 & $\mid \begin{array}{l}0 \\
\hat{\tilde{n}} \\
\stackrel{0}{2}\end{array}$ & $\mid \begin{array}{l}\bar{m} \\
\stackrel{\sim}{N}\end{array}$ & 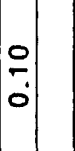 & $m$ \\
\hline . & 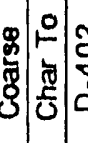 & & & & & & & & & & & & & & & & $\begin{array}{l}0 \\
0 \\
\dot{0} \\
0 \\
0\end{array}$ & & $\mid \begin{array}{c}0 \\
0 \\
0 \\
0 \\
\vdots \\
0 \\
0\end{array}$ & & & $\left|\begin{array}{l}\infty \\
0 \\
0 \\
0\end{array}\right|$ & & m \\
\hline N & 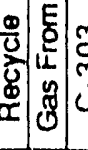 & & & & & r. & 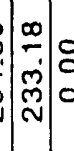 & \begin{tabular}{l|l}
0 \\
8 \\
0 \\
0
\end{tabular} & & 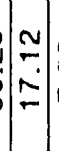 & & 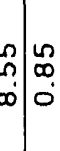 & 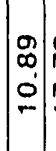 & & $\begin{array}{lll}n & 0 \\
0 \\
0\end{array}$ & & $\begin{array}{c}n \\
\infty \\
\substack{n \\
\sim}\end{array}$ & & \begin{tabular}{l}
0 \\
\hdashline \\
$N$ \\
0 \\
0 \\
0
\end{tabular} & 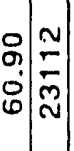 & 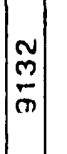 & 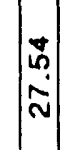 & $\frac{\infty}{0}$ & ली \\
\hline$\stackrel{\infty}{\sim}$ & $\left.\begin{array}{lll}0 \\
0 \\
0\end{array}\right)$ & & & & & 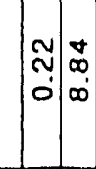 & 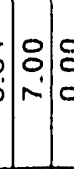 & 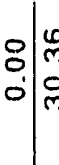 & & & & \begin{tabular}{c|c}
0 \\
\multirow{2}{*}{} \\
0
\end{tabular} & & & $\begin{array}{l}0 \\
0 \\
\end{array}$ & & $\begin{array}{l}\hat{n} \\
0 \\
0\end{array}$ & & $\left|\begin{array}{l}-5 \\
\tilde{n} \\
0 \\
0 \\
\omega\end{array}\right|$ & 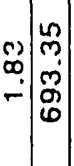 & $\left|\begin{array}{c}\hat{a} \\
\dot{a} \\
\hat{N}\end{array}\right|$ & $\mid \begin{array}{l}\mathbf{w} \\
\mathbf{w} \\
\end{array}$ & $\frac{\infty}{0}$ & $\hat{m}:$ \\
\hline$\hat{\sim}$ & 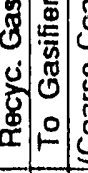 & 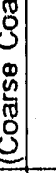 & & & & 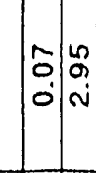 & 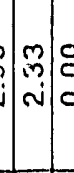 & & & & & \begin{tabular}{l|l}
8 & $\overline{0}$ \\
0 \\
0
\end{tabular} & $=$ & & $\begin{array}{l}0 \\
0\end{array}$ & & $\begin{array}{c}\text { D. } \\
\stackrel{0}{0} \\
0\end{array}$ & & $\left.\mid \begin{array}{l}1 \\
0 \\
0 \\
0\end{array}\right]$ & 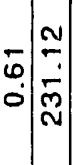 & $\mid \begin{array}{c}n \\
m \\
0 \\
0\end{array}$ & & $\left|\begin{array}{c}\infty \\
0 \\
c \\
c\end{array}\right|$ & m. \\
\hline$\stackrel{\infty}{N}$ & 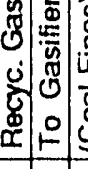 & 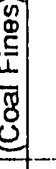 & & & & 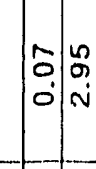 & is & \begin{tabular}{l|l}
0 \\
0 \\
0
\end{tabular} & & & & \begin{tabular}{l|l}
8 & $\overline{0}$ \\
0 \\
0
\end{tabular} & $=$ & & $\begin{array}{l}8 \\
0 \\
0 \\
0\end{array}$ & & 怘 & & $\hat{\imath}$ & 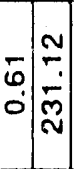 & $\mid \begin{array}{c}\omega \\
m \\
\bar{c} \\
\bar{\omega}\end{array}$ & & $\frac{\infty}{0}$ & $\hat{m} \stackrel{\circ}{0}$ \\
\hline$\stackrel{n}{n}$ & 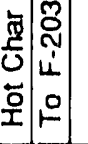 & & & $\left|\begin{array}{c}0 \\
0 \\
\infty \\
\sim \\
N\end{array}\right|$ & & & & & & & & & & & & & \begin{tabular}{|l|}
0 \\
0 \\
$N$ \\
$N$ \\
\\
\end{tabular} & & $\mid \begin{array}{l}0 \\
0 \\
0 \\
0 \\
0\end{array}$ & $\begin{array}{l}8 \\
0 \\
0 \\
0\end{array}$ & & 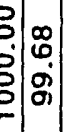 & 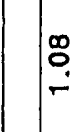 & 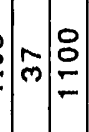 \\
\hline$\stackrel{+}{\sim}$ & \begin{tabular}{l|l}
$\frac{1}{3}$ \\
\hdashline \\
\hdashline
\end{tabular} & 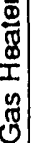 & & & & 今: & : & 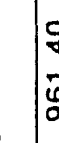 & $\begin{array}{l} \\
\vdots \\
\\
\end{array}$ & $\mid \begin{array}{l}0 \\
0 \\
0 \\
0\end{array}$ & & $\begin{array}{lll}\circ & 0 \\
\infty & 0 \\
\infty & 0 \\
0\end{array}$ & $\mid \begin{array}{l}0 \\
0 \\
0 \\
0 \\
0\end{array}$ & & & & $\begin{array}{l}n \\
0 \\
0 \\
\dot{d} \\
\sim\end{array}$ & & 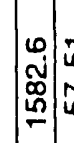 & 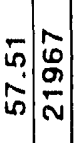 & \begin{tabular}{|l}
0 \\
$\vdots$ \\
0 \\
0 \\
$\vdots$
\end{tabular} & $\mid \begin{array}{l}\tilde{n} \\
\mathfrak{n} \\
\tilde{N}\end{array}$ & $=$ & $\hat{m}: 0$ \\
\hline ง & 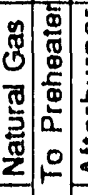 & 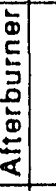 & & & & & & & mे & & & & & & & & & & $\left.\mid \begin{array}{l}n \\
\dot{m} \\
\dot{m}\end{array}\right]$ & \begin{tabular}{ll|l}
$\stackrel{n}{n}$ & $\frac{0}{\infty}$
\end{tabular} & $\left|\begin{array}{c}\infty \\
m \\
m\end{array}\right|$ & 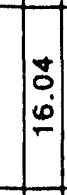 & $\left|\begin{array}{l}0 \\
\vdots \\
0\end{array}\right|$ & 分只 \\
\hline & $\overline{\mathrm{c}}$ & & $\underline{\underline{z}}$ & : & $\underline{\underline{E}}$ & 粍 & {$\left[\begin{array}{l}\frac{5}{5} \\
\frac{5}{0}\end{array}\right.$} & $\mid \begin{array}{ll}\mathbf{E} \\
\mathbf{a} \\
\mathbf{0}\end{array}$ & $\underline{E}$ & {$\left[\begin{array}{l}5 \\
\frac{5}{a} \\
\underline{a}\end{array}\right.$} & 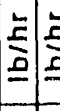 & 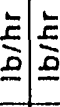 & El & 旁 & 訔 & {$\left[\begin{array}{l}5 \\
0 \\
0\end{array}\right.$} & 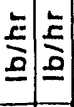 & {$\left[\begin{array}{l}\underline{E} \\
\underline{\underline{e}}\end{array}\right.$} & $\hat{E}=$ & 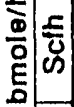 & 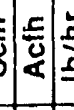 & $\begin{array}{c}5 \\
\underline{5} \\
\end{array}$ & $\begin{array}{l}2 \\
z \\
\underline{z} \\
\underline{\underline{a}}\end{array}$ & $\frac{m}{a}$ \\
\hline 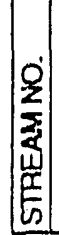 & & & $\mid \begin{array}{l}z \\
\frac{z}{8} \\
\end{array}$ & $\frac{\mathrm{I}}{\mathrm{Q}}$ & 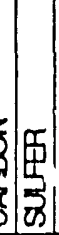 & 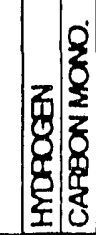 & 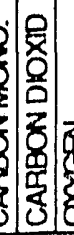 & 面展 & $\frac{3}{3}$ & 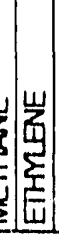 & 宸 & 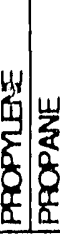 & 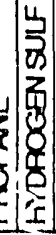 & & 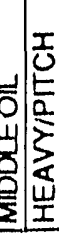 & 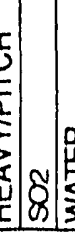 & 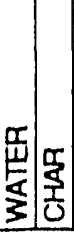 & 党: & 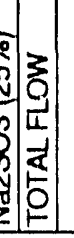 & & 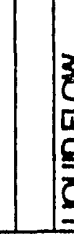 & 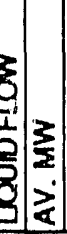 & 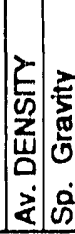 & 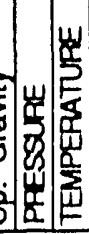 \\
\hline
\end{tabular}




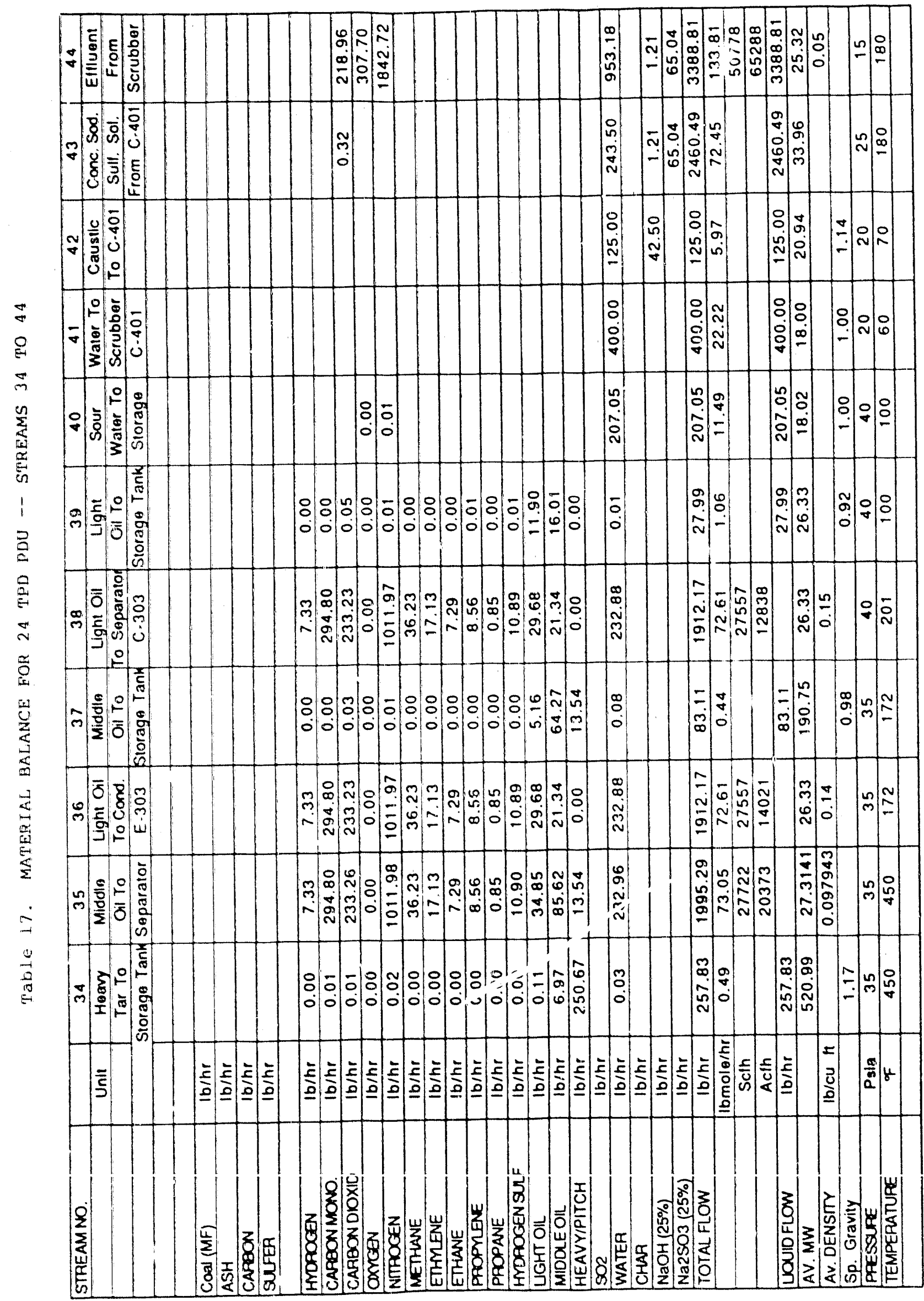




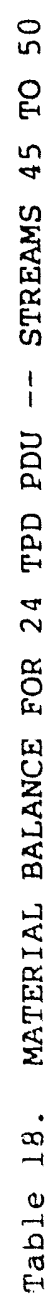

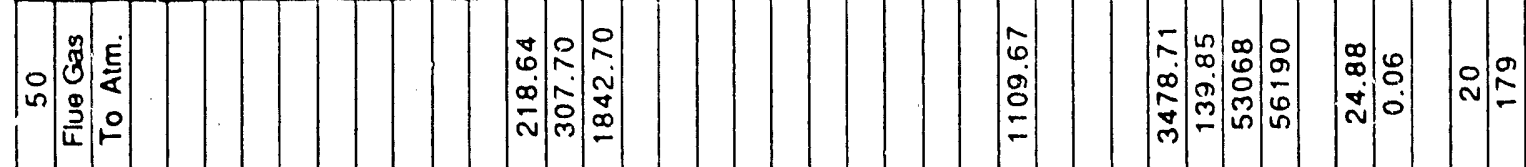

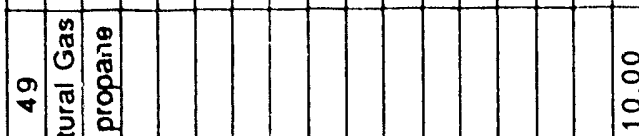

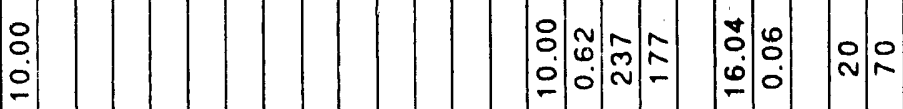

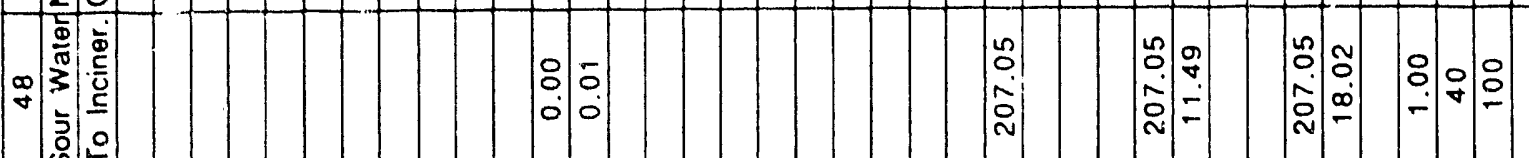

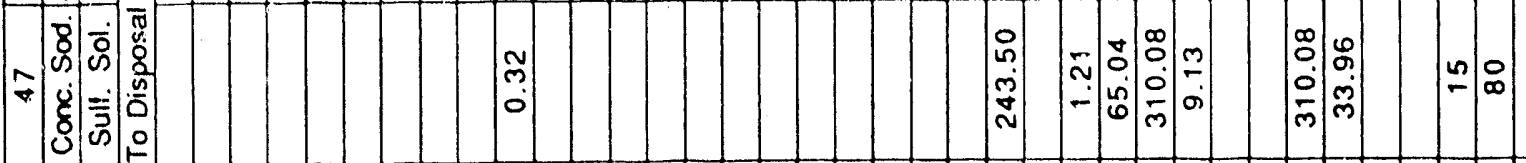

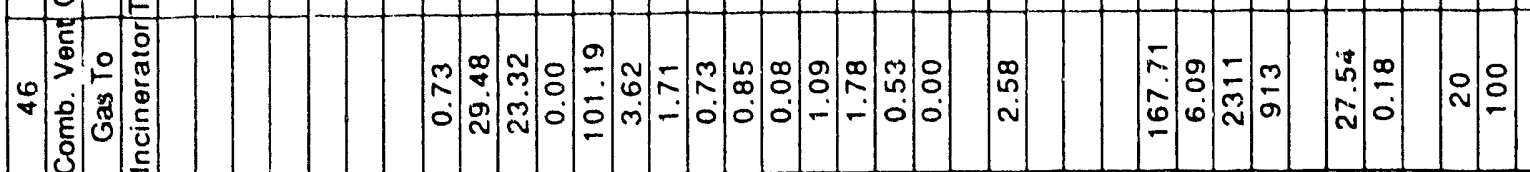

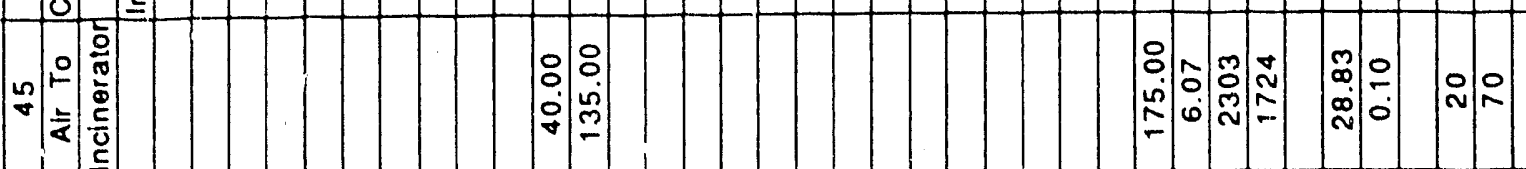

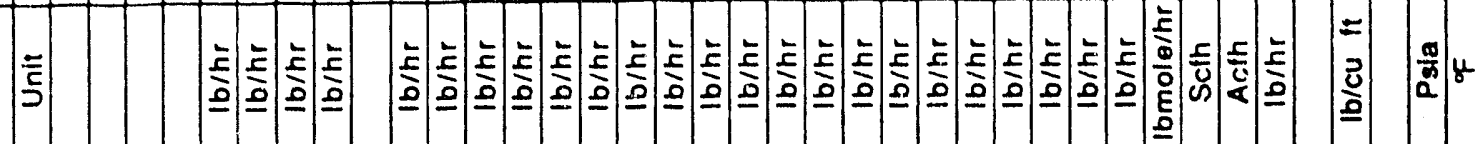

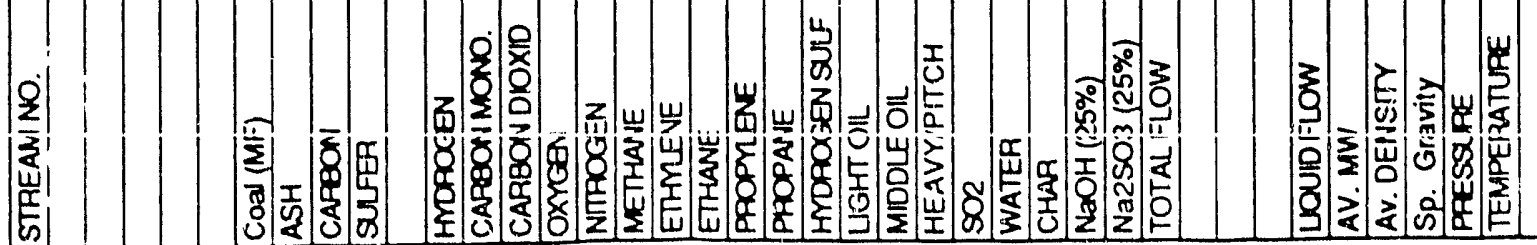


APPENDIX A. Laboratory Analyses of Solids, Liquids, and Gases for Tests Conducted During the Quarter

A-1 
Table A-1. ANALYSES OF SOLIDS FROM TEST MG-18

Test Temperature $=1178^{\circ} \mathrm{F}$

\begin{tabular}{|c|c|c|c|c|c|c|}
\hline Feed & & & $\begin{array}{l}\text { Fluid } \\
\text { Bed }\end{array}$ & $\begin{array}{c}\text { lst } \\
\text { Cyclone }\end{array}$ & $\begin{array}{c}\text { 2nd } \\
\text { Cyclone }\end{array}$ & $\begin{array}{c}\text { Carry- } \\
\text { Over }\end{array}$ \\
\hline Mixture & Coal & Diluent & Char & Char & Char & Char \\
\hline
\end{tabular}

Proximate Analysis, wt 8

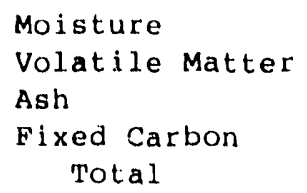

Ultimate Analysis, dry wt 8

\begin{tabular}{|c|c|}
\hline 3.59 & 6.53 \\
\hline 17.36 & 31.05 \\
\hline 11.83 & 11.44 \\
\hline 67.22 & 50.98 \\
\hline 100.00 & 100.00 \\
\hline
\end{tabular}

$$
0.65
$$

3.67

12.22

83.46

100.00

$\begin{array}{r}0.21 \\ 5.50 \\ 15.71 \\ 78.38 \\ \hline 100.00\end{array}$

$\begin{array}{r}0.77 \\ 7.25 \\ 15.64 \\ 76.34 \\ \hline 100.00\end{array}$

1.29

11.34

16.22

$\frac{71.15}{100.00} \frac{39.39}{100.00}$ .

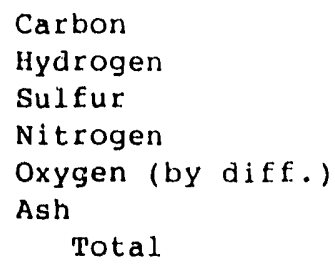

$\begin{array}{rrrrrrr}77.07 & 70.27 & 83.87 & 80.44 & 78.21 & 74.36 & 70.81 \\ 2.26 & 4.08 & 0.44 & 0.49 & 1.09 & 1.85 & 1.20 \\ 1.98 & 3.21 & 0.75 & 1.15 & 1.92 & 2.19 & 1.53 \\ 1.36 & 1.49 & 1.23 & 1.28 & 1.44 & 1.66 & 1.28 \\ 5.06 & 8.71 & 1.41 & 0.90 & 1.58 & 3.51 & 7.60 \\ \frac{12.27}{100.00} & \frac{12.24}{100.00} & \frac{12.30}{100.00} & \frac{15.74}{100.00} & \frac{15.76}{100.00} & \frac{16.43}{100.00} & \frac{17.58}{100.00} \\ \text { ND } & \text { ND } & \text { ND } & \text { ND } & \text { ND } & \text { ND } & \text { ND } \\ \text { ND } & \text { ND } & \text { ND } & \text { ND } & \text { ND } & \text { ND } & \text { ND }\end{array}$

\begin{tabular}{rrrrrrr}
0.00 & 0.00 & 0.00 & 0.00 & 0.00 & 0.00 & -- \\
14.90 & 3.30 & 19.30 & 9.81 & 0.18 & 0.00 & -- \\
30.30 & 18.50 & 31.40 & 31.75 & 1.66 & 0.65 & -- \\
-- & -- & -- & -- & -- & -- & -- \\
33.20 & 41.30 & 37.00 & 52.10 & 18.80 & 4.58 & -- \\
14.70 & 23.70 & 11.90 & 5.77 & 30.90 & 11.10 & -- \\
-- & -- & -- & -- & -- & -- & -- \\
4.27 & 9.01 & 0.17 & 0.29 & 6.45 & 3.92 & -- \\
1.20 & 2.42 & 0.00 & 0.14 & 3.31 & 1.31 & -- \\
-- & -- & -- & -- & -- & -- & -- \\
0.68 & 1.21 & 0.00 & 0.00 & 5.34 & 3.92 & -- \\
-- & -- & -- & -- & -- & -- & -- \\
0.34 & 0.33 & 0.00 & 0.14 & 6.08 & 3.27 & -- \\
0.17 & 0.00 & 0.17 & 0.00 & 2.76 & 0.65 & -- \\
0.00 & 0.11 & 0.00 & 0.00 & 3.68 & 1.31 & -- \\
0.00 & 0.00 & 0.00 & 0.00 & 3.68 & 1.96 & 0.00 \\
0.34 & 0.12 & 0.16 & 0.00 & 17.16 & 67.33 & 100.00 \\
\hline 100.00 & 100.00 & 100.00 & 100.00 & 100.00 & 100.00 & 100.00
\end{tabular}


Table A-2. ANALYSES OF SOLIDS FROM TEST MG-19

Test Temperature $=1102^{\circ} \mathrm{F}$

\begin{tabular}{|c|c|c|c|c|c|c|}
\hline $\begin{array}{c}\text { Feed } \\
\text { Mixture }\end{array}$ & Coal & Diluent & $\begin{array}{l}\text { Fluid } \\
\text { Bed } \\
\text { Char }\end{array}$ & $\begin{array}{c}\text { lst } \\
\text { Cyclone } \\
\text { Char }\end{array}$ & $\begin{array}{c}2 \text { nd } \\
\text { Cyclone } \\
\text { Char }\end{array}$ & $\begin{array}{c}\text { Carry- } \\
\text { Over } \\
\text { Char }\end{array}$ \\
\hline
\end{tabular}

Proximate Analysis, wt 8

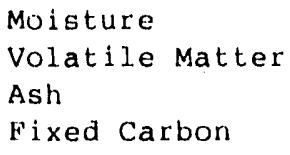

Fixed Carbon

Ultimate Analysis, dry wt 8

\begin{tabular}{rrrrrrr}
4.02 & 6.92 & 1.12 & 0.57 & 0.92 & ND & 3.93 \\
18.29 & 33.14 & 3.44 & 5.99 & 12.63 & -- & 31.43 \\
12.17 & 12.90 & 11.44 & 15.00 & 16.53 & -- & 61.07 \\
65.52 & $\frac{47.04}{100.00}$ & $\frac{84.00}{100.00}$ & $\frac{78.44}{100.00}$ & $\frac{69.92}{100.00}$ & $=$ & $=$ \\
\hline 100.00 & 10.57 \\
\hline
\end{tabular}

$\begin{array}{rrrrrrr}77.18 & 69.24 & 85.12 & 80.09 & 73.27 & \text { ND } & 36.43 \\ 2.43 & 4.51 & 0.35 & 0.81 & 1.97 & - & \text { NA } \\ 2.04 & 3.38 & 0.70 & 1.43 & 2.68 & -- & \text { NA } \\ 1.39 & 1.57 & 1.21 & 1.41 & 1.51 & - & \text { NA } \\ 4.28 & 7.51 & 1.05 & 1.17 & 3.89 & -- & \text { NA } \\ \frac{12.68}{100.00} & \frac{13.79}{100.00} & \frac{11.57}{100.00} & \frac{15.09}{100.00} & \frac{16.68}{100.00} & = & -- \\ \text { ND } & \text { ND } & \text { ND } & \text { ND } & \text { ND } & \text { ND } & \text { ND } \\ \text { ND } & \text { ND } & \text { ND } & \text { ND } & \text { ND } & \text { ND } & \text { ND }\end{array}$

Particle Density, $\mathrm{g} / \mathrm{cm}^{3}$

Particle Size Distribution, wt 8 retained on screen (mesh)

\begin{tabular}{|c|c|c|c|c|c|c|c|}
\hline 6 & 0.00 & 0.00 & 0.00 & 0.00 & 0.00 & ND & ND \\
\hline 12 & 11.30 & 1.69 & 21.30 & 20.80 & 0.00 & -- & -- \\
\hline 20 & 26.90 & 6.58 & 26.90 & 59.10 & 0.25 & -- & -- \\
\hline 30 & $-\infty$ & -- & -- & -- & -- & -- & -- \\
\hline 40 & 36.70 & 31.00 & 20.80 & 1.7 .60 & 8.17 & -- & -- \\
\hline 60 & 17.60 & 35.70 & 11.90 & 1.73 & 17.10 & -- & -- \\
\hline 70 & -- & -- & -- & -- & -- & -- & -- \\
\hline 80 & 4.64 & 16.90 & 6.26 & 0.16 & 7.18 & -- & -- \\
\hline 100 & 1.19 & 4.51 & 2.68 & 0.16 & 3.71 & -- & -- \\
\hline 120 & -- & -- & -- & -- & -- & -- & -- \\
\hline 140 & 0.83 & 2.26 & 3.58 & 0.16 & 7.92 & -- & -- \\
\hline 170 & -- & -- & -- & -- & -- & -- & -- \\
\hline 200 & 0.24 & 0.38 & 2.46 & 0.16 & 8.17 & -- & -- \\
\hline 230 & 0.12 & 0.19 & 0.67 & 0.00 & 4.46 & -- & -- \\
\hline 270 & 0.12 & 0.19 & 0.89 & 0.00 & 5.69 & -- & -- \\
\hline 325 & 0.12 & 0.19 & 0.67 & 0.00 & 4.70 & -- & -- \\
\hline \multirow[t]{2}{*}{ PAN } & 0.24 & 0.41 & 1.89 & 0.13 & 32.65 & $=$ & $=$ \\
\hline & 100.00 & 100.00 & 100.00 & 100.00 & 100.00 & -- & -- \\
\hline
\end{tabular}


Table A-3. ANALYSES OF SOLIDS FROM TEST MG-21

I'est Temperature $=1109^{\circ} \mathrm{F}$

Moisture

Volatile Matter

Ash

Fixed Carbon

$\begin{array}{rrrrrrr}\begin{array}{c}\text { Feed } \\ \text { Mixture }\end{array} & \text { Coal } & \text { Diluent } & \begin{array}{l}\text { Fluid } \\ \text { Bed } \\ \text { Char }\end{array} & \begin{array}{r}\text { lst } \\ \text { Cyclone } \\ \text { Char }\end{array} & \begin{array}{r}\text { 2nd } \\ \text { Cyclone } \\ \text { Char }\end{array} & \begin{array}{r}\text { Carry- } \\ \text { Over } \\ \text { Char }\end{array} \\ 3.46 & 5.79 & 1.12 & 0.38 & 0.74 & 1.23 & 7.46 \\ 17.34 & 31.24 & 3.44 & 6.03 & 13.15 & 13.59 & 25.42 \\ 11.39 & 11.34 & 11.44 & 14.40 & 1.3 .98 & 15.28 & 51.31 \\ \frac{67.81}{100.00} & \frac{51.63}{100.00} & \frac{84.00}{100.00} & \frac{79.19}{100.00} & \frac{72.13}{100.00} & \frac{69.90}{100.00} & \frac{15.81}{100.00}\end{array}$

\section{Ultimate Analysis, dry wt 8}

Carbon

Hydrogen

Sulfur

Nitrogen

Oxygen (by diff.)

Ash

\begin{tabular}{r} 
Heating \\
Particl \\
Particl \\
wt 8 ret \\
\hline 6 \\
12 \\
20 \\
30 \\
40 \\
60 \\
70 \\
80 \\
100 \\
120 \\
140 \\
170 \\
200 \\
230 \\
270 \\
325 \\
PAN
\end{tabular}

$\begin{array}{rrrrrrr}77.70 & 70.27 & 85.12 & 80.09 & 74.75 & 73.93 & 44.55 \\ 2.27 & 4.19 & 0.35 & 0.74 & 2.21 & 2.14 & \text { NA } \\ 1.89 & 3.07 & 0.70 & 1.39 & 2.49 & 2.07 & \text { NA } \\ 1.51 & 1.81 & 1.21 & 1.50 & 1.79 & 1.88 & \text { NA } \\ 4.83 & 8.64 & 1.05 & 1.82 & 4.68 & 4.51 & \text { NA } \\ \frac{11.80}{100.00} & \frac{12.02}{100.00} & \frac{11.57}{100.00} & \frac{14.46}{100.00} & \frac{14.08}{100.00} & \frac{15.47}{100.00} & \frac{55.45}{100.00}\end{array}$

$\begin{array}{lllllll}\text { ND } & \text { ND } & \text { ND } & \text { ND } & \text { ND } & \text { ND } & \text { ND }\end{array}$

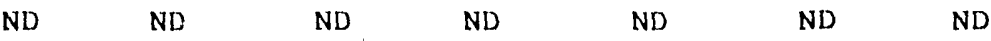

\begin{tabular}{rrrrrrr}
0.00 & 0.00 & 0.00 & 0.00 & 0.00 & 0.00 & ND \\
16.30 & 3.30 & 19.30 & 18.20 & 0.00 & 0.00 & -- \\
29.80 & 18.50 & 31.40 & 54.20 & 0.00 & 0.00 & -- \\
-- & -- & -- & -- & -- & -- & -- \\
34.00 & 41.30 & 37.00 & 23.60 & 5.36 & 0.57 & -- \\
14.00 & 23.70 & 11.90 & 2.40 & 11.10 & 2.27 & -- \\
-- & -- & -- & -- & -- & -- & -- \\
3.51 & 9.01 & 0.17 & 0.40 & 5.16 & 1.70 & -- \\
0.84 & 2.42 & 0.00 & 0.20 & 3.37 & 1.14 & -- \\
-- & -- & -- & -- & -- & -- & -- \\
0.70 & 1.21 & 0.00 & 0.20 & 7.94 & 2.27 & -- \\
-- & -- & -- & -- & -- & -- & -- \\
0.28 & 0.33 & 0.00 & 0.20 & 11.30 & 3.41 & -- \\
0.14 & 0.00 & 0.17 & 0.20 & 5.16 & 2.27 & -- \\
0.14 & 0.11 & 0.00 & 0.20 & 7.74 & 4.55 & -- \\
0.14 & 0.00 & 0.00 & 0.00 & 6.75 & 2.27 & - \\
0.15 & 0.12 & 0.16 & 0.20 & $\frac{36.12}{10}$ & 79.55 & -- \\
\hline 100.00 & 100.00 & 100.00 & 100.00 & 100.00 & 100.00 & --
\end{tabular}


Table A-4. ANALYSES OF SOLIDS FROM TEST MG-22

Test Temperature $=11.47^{\circ} \mathrm{F}$

\begin{tabular}{|c|c|c|c|c|c|c|}
\hline F'eed & & & $\begin{array}{l}\text { Fluid } \\
\text { Bed } \\
\text { Char }\end{array}$ & $\begin{array}{c}\text { lst } \\
\text { Cyclone } \\
\text { Char }\end{array}$ & $\begin{array}{c}\text { 2nd } \\
\text { Cyclone } \\
\text { Char }\end{array}$ & $\begin{array}{l}\text { Carry- } \\
\text { Over } \\
\text { Char }\end{array}$ \\
\hline Mixture & Coal & Diluent & Char & Char & Char & \\
\hline
\end{tabular}

\section{Proximate Analysis, wt 8}

Moisture
Volatile Matter
Ash

Fixed Carbon

\section{U1timate Analysis, dry wt 8}

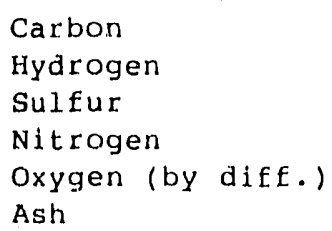

Heating Value, Btu/lb

Particle Density, $\mathrm{g} / \mathrm{cm}^{3}$

Particle Size Distribution, wt 8 retained on screen (mesh)

$\begin{array}{rrrrrrr}3.49 & 5.86 & 1.12 & 0.25 & 0.54 & 0.69 & 1.76 \\ 17.88 & 32.31 & 3.44 & 5.88 & 12.17 & 12.52 & 30.88 \\ 11.89 & 12.33 & 11.44 & 15.56 & 15.56 & 14.61 & 64.92 \\ \frac{66.74}{100.00} & \frac{49.50}{100.00} & \frac{84.00}{100.00} & \frac{78.31}{100.00} & \frac{71.73}{100.00} & \frac{72.18}{100.00} & \frac{2.44}{100.00}\end{array}$

$\begin{array}{rrrrrrr}76.63 & 68.14 & 85.12 & 78.90 & 73.66 & 74.54 & 33.92 \\ 2.26 & 4.16 & 0.35 & 0.73 & 1.89 & 2.12 & \text { NA } \\ 2.00 & 3.30 & 0.70 & 1.45 & 2.51 & 2.49 & \text { NA } \\ 1.38 & 1.55 & 1.21 & 1.39 & 1.65 & 1.70 & \text { NA } \\ 5.42 & 9.79 & 1.05 & 1.85 & 4.64 & 4.44 & \text { NA } \\ \frac{12.32}{100.00} & \frac{13.06}{100.00} & \frac{11.57}{100.00} & \frac{15.68}{100.00} & \frac{15.65}{100.00} & \frac{14.71}{100.00} & \frac{66.08}{100.00} \\ \text { ND } & \text { ND } & \text { ND } & \text { ND } & \text { ND } & \text { ND } & \text { ND } \\ \text { ND } & \text { ND } & \text { ND } & \text { ND } & \text { ND } & \text { ND } & \text { ND }\end{array}$

\begin{tabular}{|c|c|c|c|c|c|c|}
\hline 0.00 & 0.00 & 0.00 & 0.00 & 0.00 & 0.00 & ND \\
\hline 15.20 & 3.30 & 19.30 & 12.50 & 0.00 & 0.00 & -- \\
\hline 29.30 & 18.50 & 31.40 & 62.26 & 0.19 & 0.00 & -- \\
\hline -- & -.. & -- & -- & -- & -- & -- \\
\hline 33.48 & 41.30 & 37.00 & 22.20 & 7.62 & 1.87 & -- \\
\hline 15.20 & 23.70 & 1.1 .90 & 1.78 & 15.10 & 7.46 & -- \\
\hline-- & -- & -- & -- & -- & -- & -- \\
\hline 4.20 & 9.01 & 0.17 & 0.36 & 6.88 & 4.10 & -- \\
\hline 1.18 & 2.42 & 0.00 & 0.18 & 4.09 & 3.36 & -- \\
\hline-- & -- & -- & -- & -- & -- & -- \\
\hline 0.79 & 1.21 & 0.00 & 0.18 & 9.48 & 4.85 & - \\
\hline-- & -- & - & -- & -- & -- & -- \\
\hline 0.39 & 0.33 & 0.00 & 0.18 & 11.00 & 11.90 & -- \\
\hline 0.00 & 0.00 & 0.17 & 0.18 & 5.20 & 1.49 & -- \\
\hline 0.13 & 0.11 & 0.00 & 0.00 & 6.88 & 7.84 & -- \\
\hline 0.00 & 0.00 & 0.00 & 0.00 & 6.32 & 2.99 & -- \\
\hline 0.13 & 0.12 & 0.16 & 0.18 & 27.24 & 54.14 & $=-$ \\
\hline 100.00 & 1.00 .00 & 100.00 & 100.00 & 1.00 .00 & 100.00 & -- \\
\hline
\end{tabular}

$A-6$ 
Table A-5. ANALYSES OF SOLIDS FROM TEST MG-25

Test Temperature $=1134^{\circ} \mathrm{F}$

\begin{tabular}{c} 
Feed \\
Mixture Coal Diluent $\begin{array}{c}\text { Fluid } \\
\text { Bed Char Cyclone Cyclone Over } \\
\text { Char Char Char }\end{array}$ \\
\hline
\end{tabular}

Proximate Analysis, wt 8

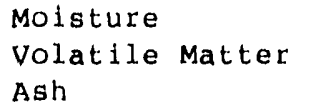

Fixed Carbon

Ultimate Analysis, dry wt 8

$\begin{array}{rrrrrrr}2.86 & 5.34 & 0.38 & 0.27 & 0.38 & 0.34 & 0.67 \\ 16.27 & 26.51 & 6.03 & 7.44 & 15.33 & 14.30 & 22.72 \\ 12.92 & 11.44 & 14.40 & 16.63 & 17.34 & 16.36 & 22.29 \\ \frac{67.95}{100.00} & \frac{56.71}{100.00} & \frac{79.19}{100.00} & \frac{75.66}{100.00} & \frac{66.95}{100.00} & \frac{68.50}{100.00} & \frac{54.32}{100.00}\end{array}$

$\begin{array}{rrrrrrr}76.21 & 72.33 & 80.09 & 76.56 & 69.67 & 70.89 & 77.56 \\ 2.16 & 3.58 & 0.74 & 1.05 & 2.38 & 2.35 & \text { NA } \\ 2.09 & 2.79 & 1.39 & 1.84 & 2.99 & 3.04 & \text { NA } \\ 1.38 & 1.26 & 1.50 & 1.44 & 1.67 & 1.64 & \text { NA } \\ 4.86 & 7.90 & 1.82 & 2.43 & 5.88 & 5.66 & \text { NA } \\ \frac{13.30}{100.00} & \frac{12.14}{100.00} & \frac{14.46}{100.00} & \frac{16.68}{100.00} & \frac{17.41}{100.00} & \frac{16.42}{100.00} & \frac{22.44}{100.00}\end{array}$

$\begin{array}{lllllll}\text { ND } & \text { ND } & \text { ND } & \text { ND } & \text { ND } & \text { ND } & \text { ND }\end{array}$

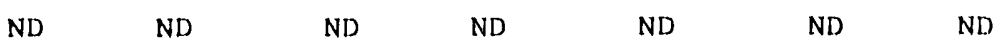

$\begin{array}{rrrllll}\text { ND } & 0.00 & 0.00 & \text { ND } & \text { ND } & \text { ND } & \text { ND } \\ -- & 3.30 & 19.30 & -- & -- & -- & -- \\ -- & 18.50 & 31.40 & -- & -- & -- & -- \\ -- & -- & -- & -- & -- & -- & -- \\ -- & 41.30 & 37.00 & -- & -- & -- & -- \\ -- & 23.70 & 11.90 & -- & -- & -- & -- \\ -- & -- & -- & -- & -- & -- & -- \\ -- & 9.01 & 0.17 & -- & -- & -- & -- \\ -- & 2.42 & 0.00 & -- & -- & -- & -- \\ -- & -- & -- & -- & -- & -- & -- \\ -- & 1.21 & 0.00 & -- & -- & -- & -- \\ -- & -- & -- & -- & -- & -- & -- \\ -- & 0.33 & 0.00 & -- & -- & -- & -- \\ -- & 0.00 & 0.17 & -- & -- & -- & -- \\ -- & 0.11 & 0.00 & -- & -- & -- & -- \\ -- & 0.00 & 0.00 & -- & -- & -- & -- \\ -- & 0.12 & 0.16 & -- & -- & -- & -- \\ -- & 100.00 & 100.00 & -- & -- & -- & --\end{array}$


Table A-6. ANALYSES OF SOLIDS FROM TEST' MG-28

Test Temperature $=1150^{\circ} \mathrm{F}$

\begin{tabular}{|c|c|c|c|c|c|c|}
\hline Feed & & & $\begin{array}{l}\text { Fluid } \\
\text { Bed }\end{array}$ & $\begin{array}{c}\text { 1st } \\
\text { Cyclone } \\
\text { Char }\end{array}$ & $\begin{array}{l}\text { 2nd } \\
\text { Cyclone } \\
\text { Char }\end{array}$ & $\begin{array}{l}\text { Carry- } \\
\text { Over } \\
\text { Char }\end{array}$ \\
\hline Mixture & Coal & Diluent & Char & Char & Char & Char \\
\hline
\end{tabular}

Proximate Analysis, wt 8

\author{
Molsture \\ Volatile Matter \\ Ash \\ Fixed Carbon
}

\section{U1timate Analysis, dry wt 8}

Carbon
Hydrogen
Sulfur
Nitrogen
Oxygen (by diff.)
Ash

Heating Value, Btu/lb

Particle Density, $\mathrm{g} / \mathrm{cm}^{3}$

Particle Size Distribution, wt 8 retalned on screen (mesh)

$\begin{array}{rrrrrrr}0.80 & 0.16 & 1.12 & 0.17 & 0.19 & 0.02 & 1.58 \\ 9.23 & 20.81 & 3.44 & 3.94 & 7.92 & 17.37 & 13.46 \\ 11.55 & 1.1 .77 & 11.44 & 12.77 & 16.10 & 31.56 & 8.31 \\ \frac{78.42}{100.00} & \frac{67.26}{100.00} & \frac{84.00}{100.00} & \frac{83.12}{100.00} & \frac{75.79}{100.00} & \frac{51.05}{100.00} & \frac{76.65}{100.00}\end{array}$

$\begin{array}{rrrrrrr}83.02 & 78.82 & 85.12 & 83.51 & 77.05 & 57.54 & 91.56 \\ 1.49 & 3.77 & 0.35 & 0.64 & 1.83 & 2.24 & \text { NA } \\ 0.98 & 1.54 & 0.70 & 0.95 & 1.52 & 0.18 & \text { NA } \\ 1.29 & 1.45 & 1.21 & 1.36 & 1.34 & 1.40 & \text { NA } \\ 1.58 & 2.64 & 1.05 & 0.75 & 2.13 & 7.07 & \text { NA } \\ \frac{11.64}{100.00} & \frac{11.78}{100.00} & \frac{1.1 .57}{100.00} & \frac{12.79}{100.00} & \frac{16.13}{100.00} & \frac{31.57}{100.00} & \frac{8.14}{100.00} \\ \text { ND } & \text { ND } & \text { ND } & \text { ND } & \text { ND } & \text { ND } & \text { ND } \\ \text { ND } & \text { ND } & \text { ND } & \text { ND } & \text { ND } & \text { ND } & \text { ND }\end{array}$

\begin{tabular}{|c|c|c|c|c|c|}
\hline 0.00 & 0.00 & ND & ND & ND & ND \\
\hline 3.30 & 19.30 & -- & -- & $\cdots$ & -- \\
\hline 18.50 & 31.40 & -- & -- & -- & -- \\
\hline-- & -- & -- & -- & -- & -- \\
\hline 41.30 & 37.00 & -- & -- & -- & -- \\
\hline 23.70 & 11.90 & -- & -- & -- & -- \\
\hline -- & $-\cdots$ & -- & -- & -- & $\ldots$ \\
\hline 9.01 & 0.17 & -- & -- & -- & -- \\
\hline 2.42 & 0.00 & -- & -- & - & -- \\
\hline-- & -- & -- & -- & -- & -- \\
\hline 1.21. & 0.00 & - & -- & -- & -- \\
\hline- & -- & -- & -- & -- & -- \\
\hline 0.33 & 0.00 & -- & -- & $\cdots$ & -- \\
\hline 0.00 & 0.17 & -- & - & -- & -- \\
\hline 0.11 & 0.00 & - & - & -- & -- \\
\hline 0.00 & 0.00 & - & - & -- & -- \\
\hline 0.12 & 0.16 & $=$ & $=$ & $=$ & $=$ \\
\hline 100.00 & 100.00 & -- & $\cdots$ & -- & $\cdots$ \\
\hline
\end{tabular}

A-8 
Table A-7. OILS AND TARS ANALYSUS

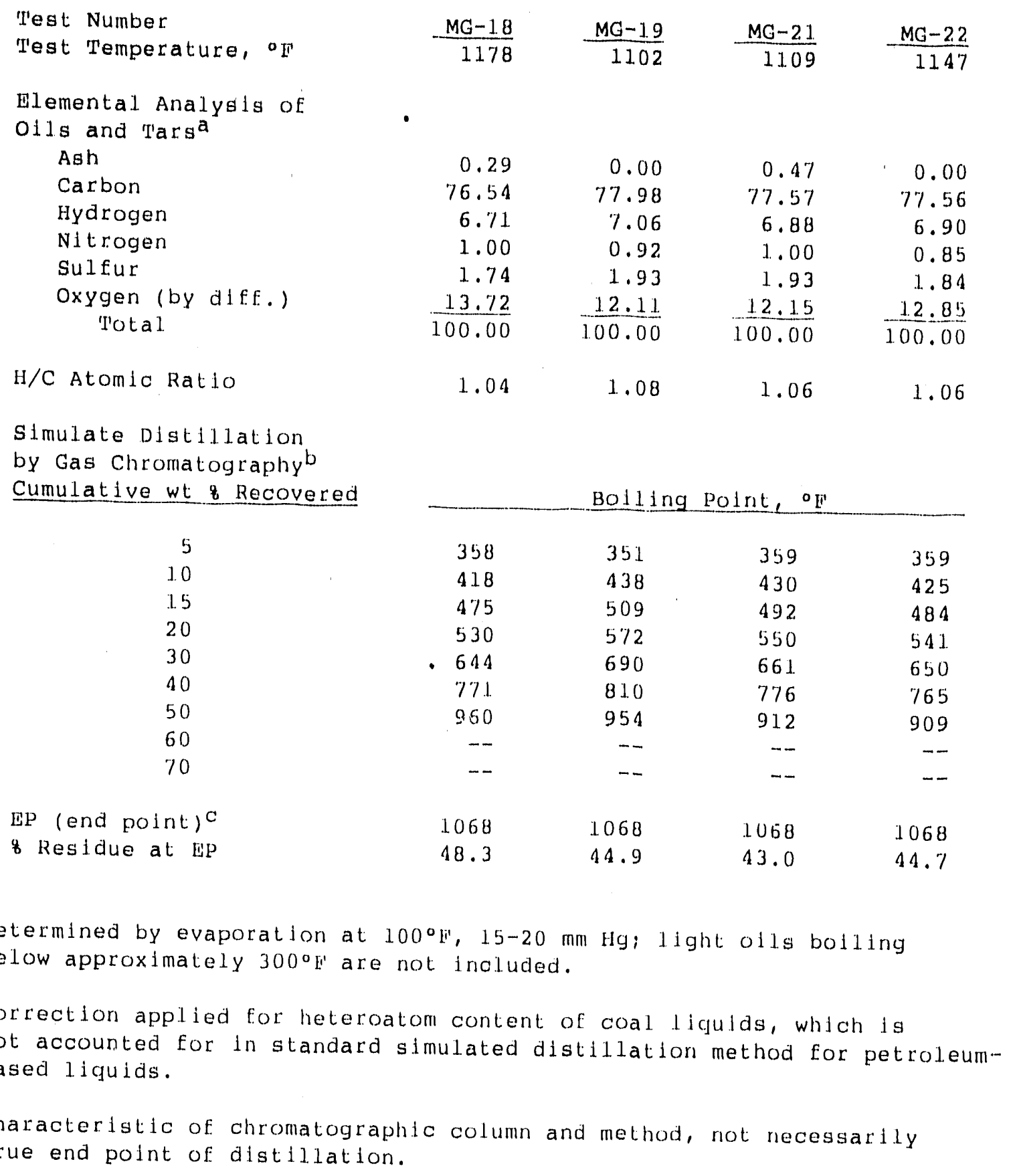

a Determined by evaporation at $100^{\circ} \mathrm{F}^{\prime}, 15-20 \mathrm{~mm} \mathrm{Hg}$; light olls boiling below approximately $300^{\circ} \mathrm{F}$ are not included.

b correction applied for heteroatom content of coal liqulds, which is not accounted for in standard simulated distillation method for petroleum-

C Charactertstic of chromatographic column and method, not necessarily true end point of distillation. 
Table A-\%, Cont, OTLS AND T'ARS ANALYSES

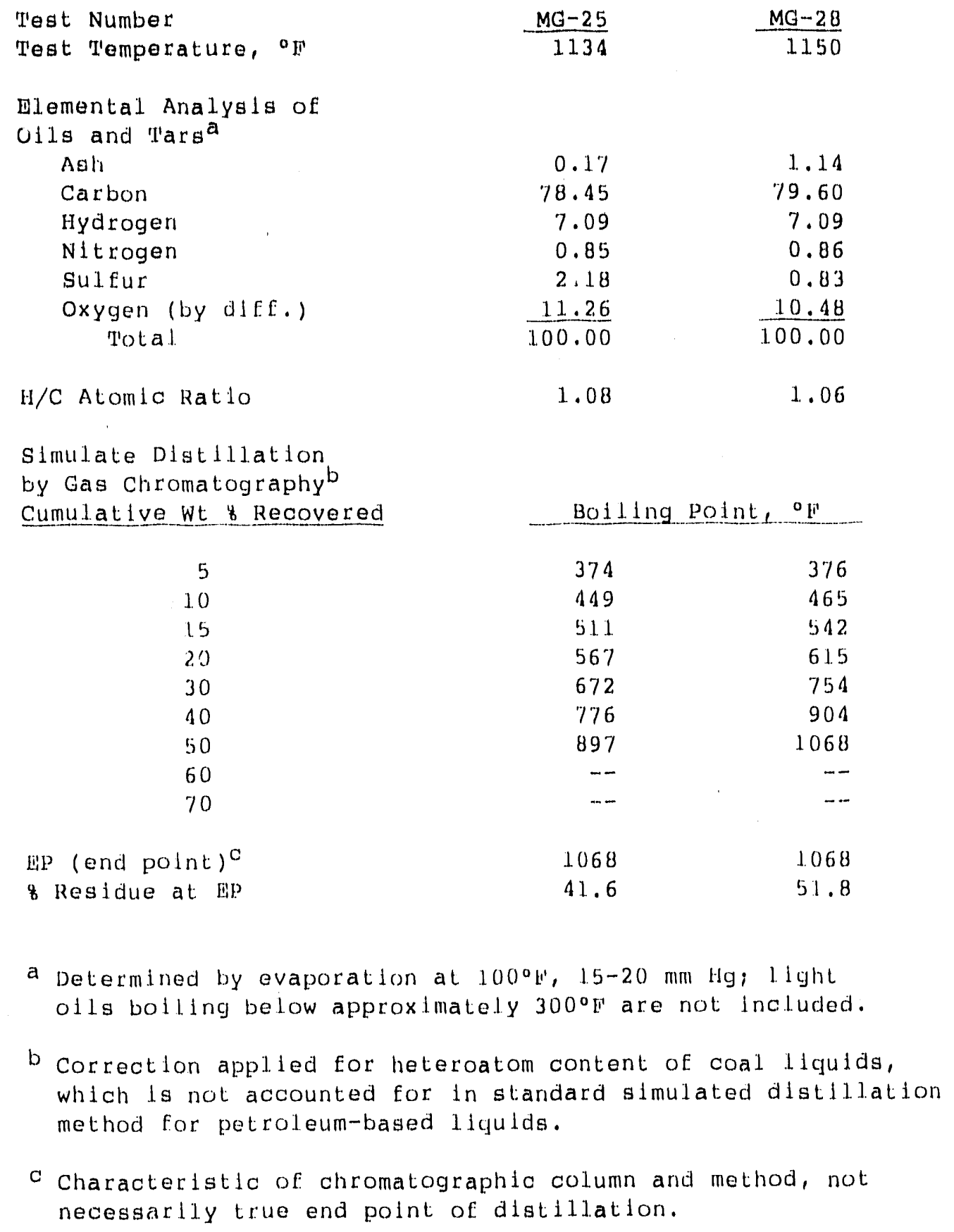


'I'able A-8. COMPONEN'I' ANALYSES OF' FULL-RANGE OILS AND IIARS

\begin{tabular}{|c|c|c|c|c|c|c|}
\hline $\begin{array}{l}\text { Test Number } \\
\text { Test Temperature, op }\end{array}$ & $M G-18$ & $M G-19$ & $\mathrm{MG}-21$ & $\frac{M G-22}{1197}$ & $\frac{M G-25}{112}$ & $\frac{M G-28}{1+50}$ \\
\hline $\begin{array}{l}\text { Component, wt of of } \\
\text { total of } 1 \text { s and tars }\end{array}$ & & & & & & \\
\hline Benzene & 0.7 & 0.1 & 0.5 & 0.8 & 0.3 & 0.5 \\
\hline Toluene & 0.8 & 0.3 & 0.4 & 0.7 & 0.5 & 0.7 \\
\hline xylenes & 0.5 & 0.2 & 0.3 & 0.4 & 0.4 & 0.5 \\
\hline Wthylbenzene & 0.1 & 0.04 & 0.3 & 0.1 & 0.1 & 0.1 \\
\hline Indene & 0.3 & 0.1 & 0,1 & 0.2 & 0.1 & 0.2 \\
\hline styrene & 0.2 & 0.1 & 0.1 & 0.1 & 0.1 & 0.05 \\
\hline other Light olls & 4.8 & 5.1 & 22.0 & $4 . \%$ & 4.2 & 7.3 \\
\hline I'otal Light of b & $\% .4$ & 6.2 & 23.7 & 7.0 & 5.7 & 9.3 \\
\hline Phenol & 0.8 & 0.6 & 0.6 & 0.8 & 0.8 & 0.4 \\
\hline Cresols & $2 \cdot 1$ & 1.6 & 1.6 & 2.1 & 1.9 & 1. 0 \\
\hline xylenols & 1.9 & 1.6 & 1.9 & 2.3 & 3.8 & 1. 6 \\
\hline Naphthalene & 0.5 & 0.3 & 0.1 & 0.4 & 0.1 & 0.6 \\
\hline Other Mldale olls & 14.4 & 11.8 & 10.1 & 13.4 & 11.0 & 9.7 \\
\hline Total Middle oll. & 19.7 & 15.9 & 14.9 & 19.0 & $1 \% .6$ & 1.3 .3 \\
\hline Heavy $011^{d}$ & 12.9 & 13.5 & 11.4 & 13.1 & 15.2 & 10.8 \\
\hline Pitche & 60.0 & 61.4 & 50.0 & 60.6 & 61.5 & 66.6 \\
\hline Total ofls and 'I'als & 100.0 & 100.0 & 100.0 & 100.0 & 100.0 & 1.00 .0 \\
\hline
\end{tabular}

a Includes light olls which are not included In the olls and tars of: I'able $A-5$.

b Atmospherlo bolling polnt< $360^{\circ} \mathrm{F}$; estimated from slmulated dlst lliation data.

C Atmospherlo bolling point $360^{\circ}$ to $590^{\circ} \mathrm{Fr}$.

a Atmospheric boliling polnt $590^{\circ}$ to $750^{\circ} \mathrm{F}$.

e Atmospherla bolling point $>750^{\circ} \mathrm{F}$. 
Ilable A-9. GAS COMPOSITIONS

I'eat Number

T'est 'Temperature, ${ }^{\circ} \mathrm{F}$

Component

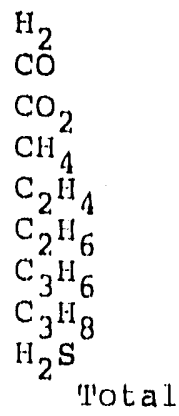

Moleoular Weight

Higher Heating Value, Btu/lb
MG-1

1178

$M G-19$

1102

$M G-2$

$\frac{M G-21}{1109}$

$\underline{M G-22}$

$\frac{M G-25}{1134} \quad \frac{M G-28}{1150}$

Mol of in gas, nitrogen-free

$\begin{array}{rrrrrr}40.4 & 11.1 & 18.6 & 23.1 & 1 \% .4 & 27.1 \\ 11.5 & 13.5 & 13.6 & 13.1 & 1.5 .1 & 3.0 \\ 9.5 & 9.6 & 10.0 & 7.5 & 11.3 & 8.2 \\ 26.0 & 40.0 & 38.3 & 3 \% .0 & 34.9 & 45.2 \\ 4.8 & 5.7 & 5.9 & 5.7 & 4.7 & 5.3 \\ 3.2 & 7.4 & 6.7 & 6.0 & 5.4 & 5.4 \\ 2.2 & 3.0 & 3.0 & 3.8 & 3.0 & 2.6 \\ 0.5 & 1.3 & 1.4 & 1.3 & 1.1 & 1.0 \\ 1.9 & 2.4 & 2.5 & 2.5 & \frac{7.1}{1.5} & \frac{1.4}{100.0}\end{array}$

$\begin{array}{llllll}16.5 & 21.2 & 21.1 & 19.8 & 22.2 & 17.5\end{array}$ $\begin{array}{llllll}640 & 841 & 823 & 824 & 769 & 830\end{array}$

$6 W P / 610890-d / R P P$ 

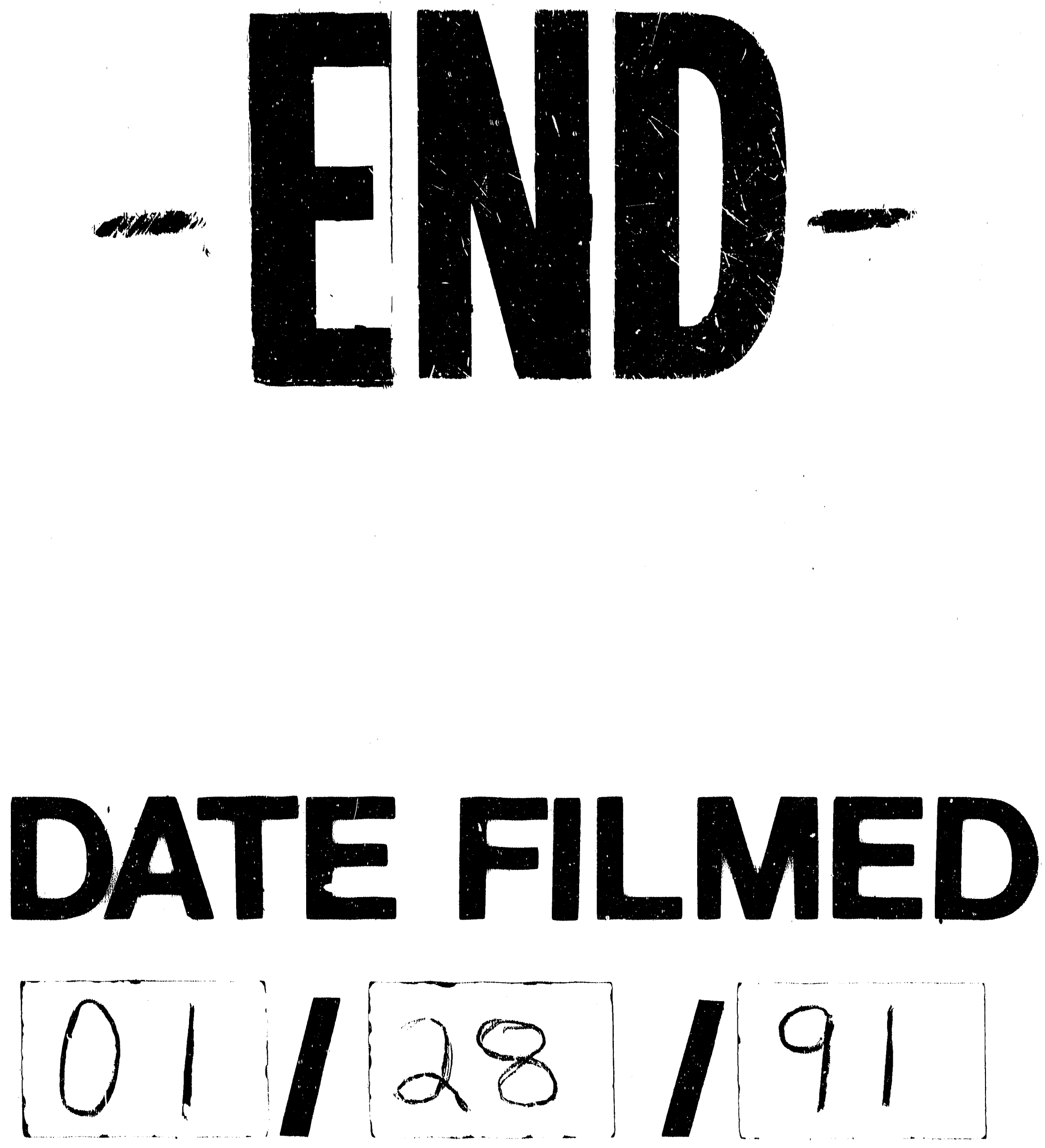